\title{
WestVirginiaUniversity
}

THE RESEARCH REPOSITORY @ WVU

Graduate Theses, Dissertations, and Problem Reports

2019

\section{Genetic and Pharmacologic Studies Towards Prevention of opioid use disorder}

Shane W. Kaski

swkaski@mix.wvu.edu

Follow this and additional works at: https://researchrepository.wvu.edu/etd

\section{Recommended Citation}

Kaski, Shane W., "Genetic and Pharmacologic Studies Towards Prevention of opioid use disorder" (2019). Graduate Theses, Dissertations, and Problem Reports. 4124.

https://researchrepository.wvu.edu/etd/4124

This Dissertation is protected by copyright and/or related rights. It has been brought to you by the The Research Repository @ WVU with permission from the rights-holder(s). You are free to use this Dissertation in any way that is permitted by the copyright and related rights legislation that applies to your use. For other uses you must obtain permission from the rights-holder(s) directly, unless additional rights are indicated by a Creative Commons license in the record and/ or on the work itself. This Dissertation has been accepted for inclusion in WVU Graduate Theses, Dissertations, and Problem Reports collection by an authorized administrator of The Research Repository @ WVU.

For more information, please contact researchrepository@mail.wvu.edu. 
$\underline{\text { Genetic and Pharmacologic Studies Towards Prevention of opioid use disorder }}$

Shane West Kaski

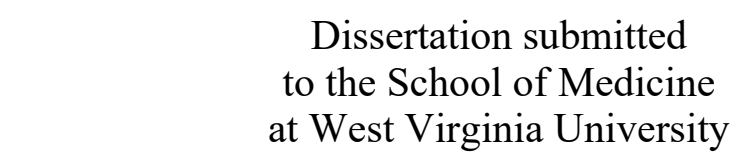

In partial fulfillment of the requirements for the degree of

Doctor of Philosophy in

Cellular and Integrative Physiology

Bernard G. Schreurs, Ph.D., Chair

David P. Siderovski, Ph.D.

Vincent Setola, PhD.

Walter R. Byrd Jr., M.D.

Werner Geldenhuys, Ph.D., M.S.

Department of Physiology and Pharmacology

\section{Morgantown, West Virginia 2019}

Keywords: kappa opioid receptor, addiction, biased agonist

Copyright 2019 Shane West Kaski 


\section{ABSTRACT \\ Genetic and Pharmacologic Studies Towards Prevention of opioid use disorder Shane West Kaski}

Endogenous opioids mediate both analgesic and affective responses to stress. While the mu opioid receptor (MOR) produces the reinforcing euphoric effects responsible for the high abuse potential of traditional opioid analgesics, the kappa opioid receptor (KOR) is hypothesized to mediate the dysphoric component of stress. With increasing rates of opioid addiction, extensive research efforts are focused on better understanding each of these systems and how they interact, with the goal of developing less addictive pain management strategies and better approaches to addiction treatment. With this in mind, we conducted both clinical and preclinical studies aimed at developing better treatment strategies for opioid use and the management of patients with opioid use disorder (OUD). First, we assessed a local cohort of patients with (OUD) for a collection of single nucleotide polymorphisms (SNPs) related to reward processing, with the goal of furthering efforts to develop a gene-based screening mechanism for OUD risk assessment. Second, we conducted preclinical assessments of the G protein-biased KOR agonist nalfurafine as a potential adjuvant medication for increasing the therapeutic efficacy of opioid-based analgesia. Genetic analysis of OUD patients identified two SNPs within the gene encoding the mu opioid receptor, one SNP within the gene encoding the serotonin $2 \mathrm{~B}\left(5-\mathrm{HT}_{2 \mathrm{~B}}\right)$ receptor, and one SNP within the gene encoding Regulator of G protein Signaling 2 (RGS2), with the frequency of each SNP varying significantly from that observed in reference populations of European descent. Preclinical investigations with nalfurafine use in mice demonstrated a greater analgesic synergy when co-administered with morphine than morphine co-administered with the unbiased KOR agonist U50,488. As G protein-biased KOR agonists are hypothesized to produce less dysphoria (a therapeutically limiting side effect of KOR agonists), they may present a viable method for reducing the dose of MOR-targeting analgesic necessary for adequate pain relief, thereby reducing the likelihood of developing OUD. Further research is necessary to identify any antitherapeutic effects of co-administering these two classes of drugs, as well as the range of pain modalities for which this approach is efficacious. 


\section{Acknowledgements}

Over the course of these three years in the labs of Dr. Siderovski and Dr. Setola, I have grown more as both a scientist and person than I ever expected. Beginning as an aggressively type A medical student planted firmly on the upslope of the Kruger Curve and fully intent on solving addiction in a semester, I now leave as an aggressively type A physician scientist, having rounded the curve to the understanding that I know nothing compared to the true complexity of biological science. The journey has been both intensely frustrating and unendingly interesting, and I don't think I could have made the journey without the help of those around me.

First, to Dr. Siderovski. Your endless support and patience are truly amazing. Your openness to scientific inquiry and endless positivism never fail to re-energize an exhausted and overwhelmed graduate student. The speed and enthusiasm with which you respond to requests is truly legendary and without peer. I pity those without a mentor like you and can only hope that I was deserving.

Second, to Dr. Setola. As my hands-on co-mentor, what I have learned from you about science, and indeed about life, is rivaled only by those who raised me. Though at times contentious, I deeply respect your depth of knowledge, appreciation of scientific design, and your willingness to challenge me to be more thorough and thoughtful in all things. You were always willing to have frank discussion about the datums, and the lessons I learned from you have made me a better scientist and a better person. For that I thank you.

To my dissertation committee, Dr. Bernard Schreurs, Dr. Werner Geldenhuys, Dr. Walter Byrd, Dr. David Siderovski and Dr. Vince Setola, your support and input has been invaluable and greatly appreciated.

To my lab mates... I don't know how I got so lucky. I joined the lab without knowing either of you and I could not have chosen better. Adam, your ability to be a contrarian is unrivaled and made for both amazing discussions, and entertaining lab meetings. You were always thoughtful in discussions of my project and were truly helpful in that regard. Next time I need to find holes in literature (or need someone to agonize over animal breeding), I'll call you up. 
Joshua, I think the only people I've spent more time with on this planet are my parents, yet not once did I feel like yelling at you. Your unflappability is impressive. You were truly my third mentor and I appreciate your patience, advice, and friendship. P.S. Give me my rising star...

To Audra, Matt and Grant, you all were amazing to have in my life while going through the ups and downs of $\mathrm{PhD}$ life. I appreciate all the fun we had together and your support when times were tough.

Lastly, to my parents. I didn't come home or call as much as I know I should have, but your support and encouragement now, and every moment previous, has pushed me to get to where I am today. You are truly the best parents I could have asked for, and no amount of thanks is sufficient. 


\section{$\underline{\text { Dedication }}$}

To my brother, whose kind heart and self-less nature drives my focus and dedication to helping those struggling with addiction. 


\section{$\underline{\text { Table of Contents }}$}

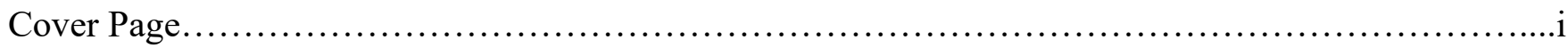

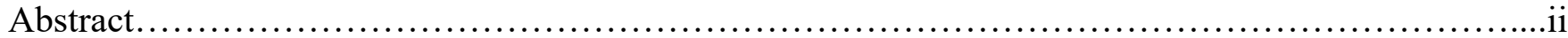

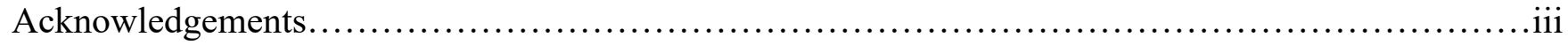

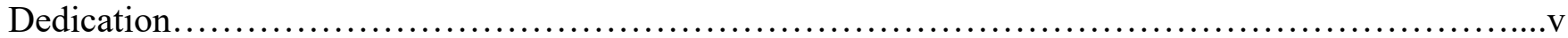

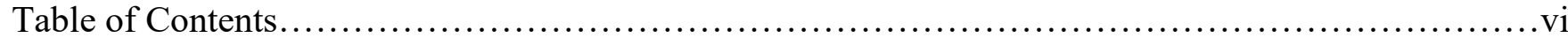

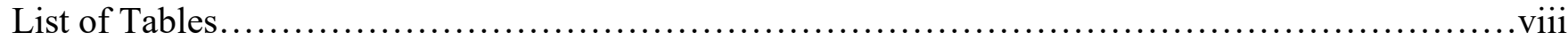

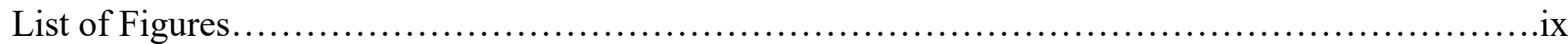

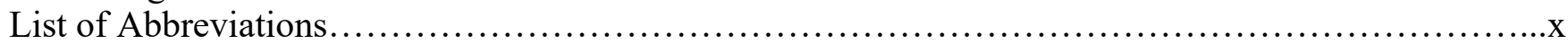

1 Chapter One: Introduction

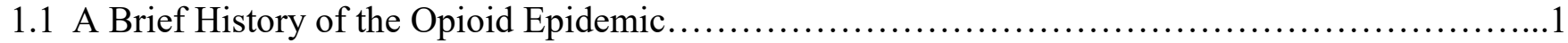

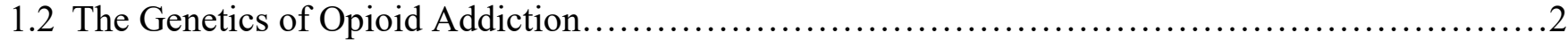

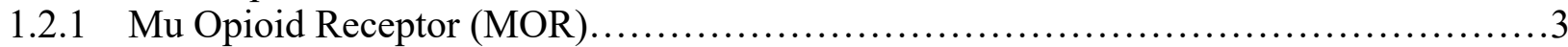

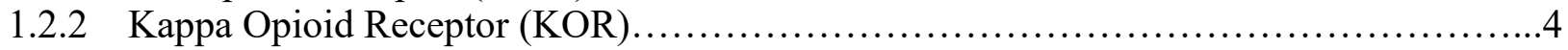

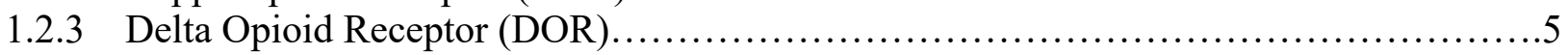

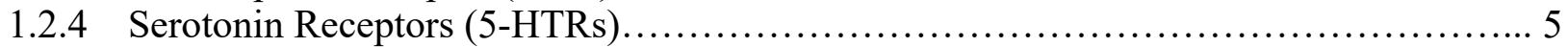

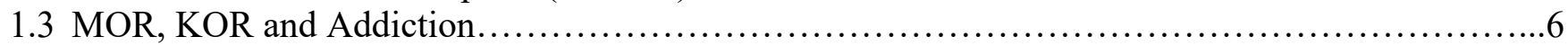

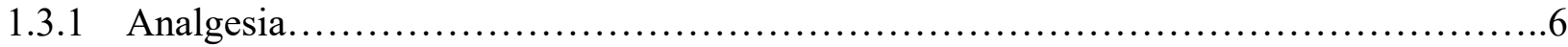

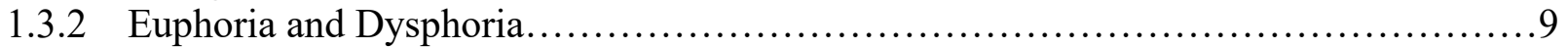

1.3.2.a Euphoria, reward, and the mu opioid receptor.............................10

1.3.2.b Dysphoria, altered set-points, and the kappa opioid receptor.................12

1.4 Pharmacological approaches for improving opioid analgesics.................................. 16

1.4.1 Combining MOR and KOR activation

1.4.2 Biased Agonism: All the good with none of the bad?...................................................18

1.4.2.a G protein-biased MOR agonists.......................................19

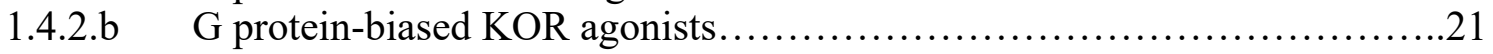

1.5 References.

2 Chapter Two: Four single nucleotide polymorphisms in genes involved in neuronal signaling are associated with opioid use disorder (OUD) in West Virginia........................................ 45

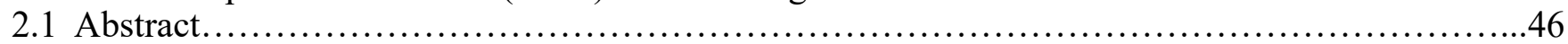

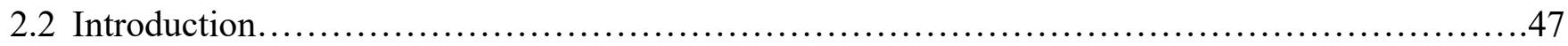

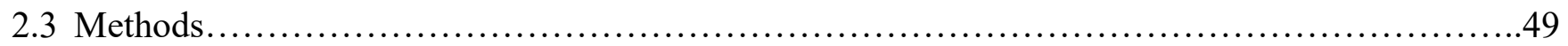

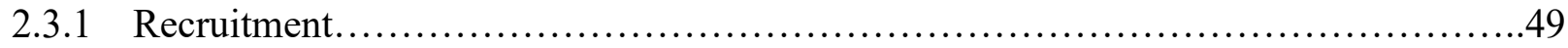

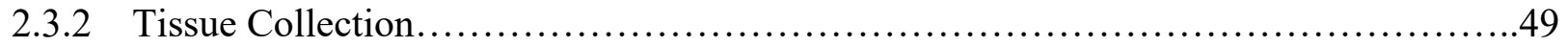

2.3.3 Genomic DNA Extraction........................................................ 49

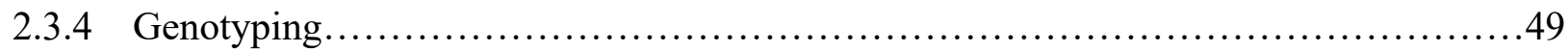

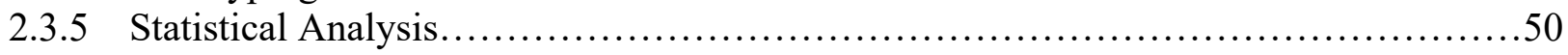

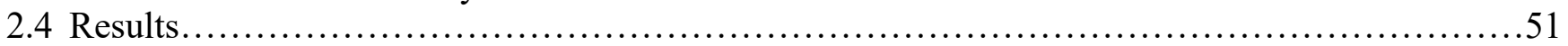

2.4.1 OPRM1 res9479757 (mu opioid receptor gene variant) .........................51

2.4.2 OPRM1 rs1799971 (mu opioid receptor gene variant) ..............................52

2.4.3 RGS2 rs4606 (Regulator of G protein Signaling-2 gene variant)...................52

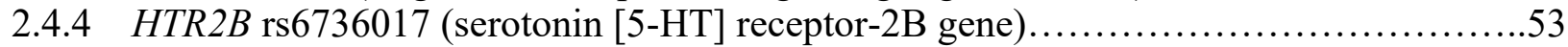

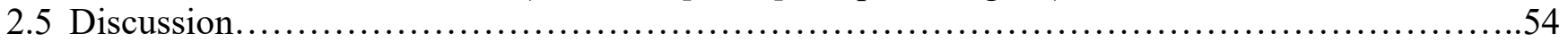

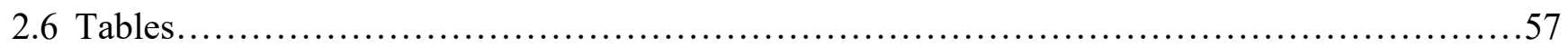

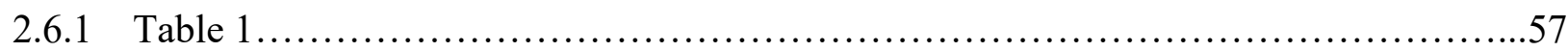

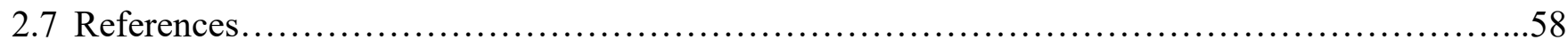


3 Chapter Three: Preclinical testing of nalfurafine as an opioid-sparing adjuvant that potentiates analgesia by

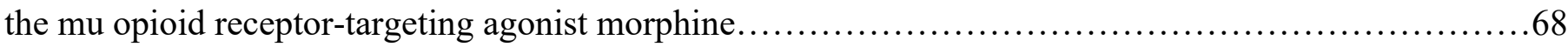

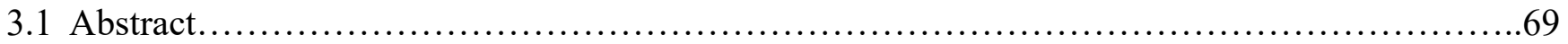

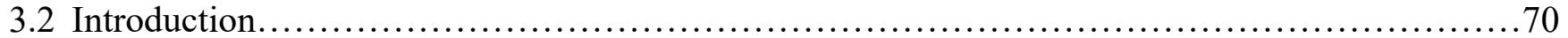

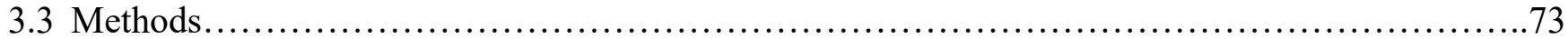

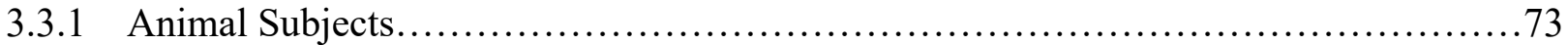

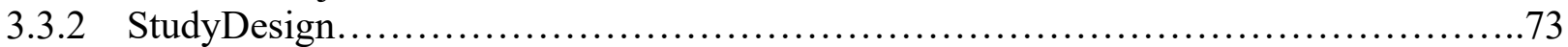

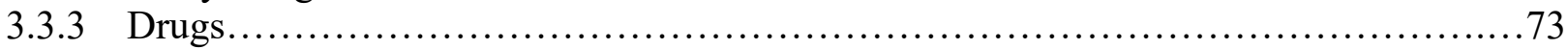

3.3.4 Measurement of Signaling Bias................................................... 74

3.3.5 Calculation of Bias Factor....................................................... 75

3.3.6 Warm Water Tail Withdrawal..................................................... 75

3.3.7 Hot Plate Analgesia Test........................................................ 75

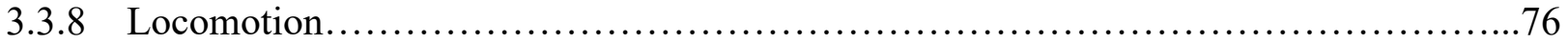

3.3.9 Conditioned Place Preference/Aversion..........................................76

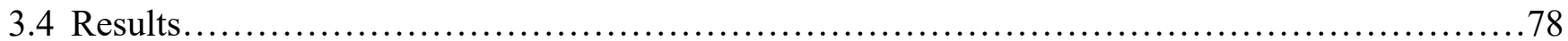

3.4.1 Selection of nalfurafine as KOR biased agonist under consideration as a possible morphine adjuvant...................................................... 78

3.4.2 Spinal anti-nociception by nalfurafine......................................... 78

3.4.3 Enhancement of morphine-induced supraspinal analgesia by nalfurafine coadministration............................................................... 79

3.4.4 Locomotor suppression by nalfurafine administration and co-administration

3.4.5 Dose-dependent conditioned place aversion by nalfurafine $\ldots \ldots \ldots \ldots \ldots \ldots \ldots \ldots \ldots . . . \ldots 80$

3.4.6 Modulation of morphine-induced conditioned place preference by nalfurafine.........81

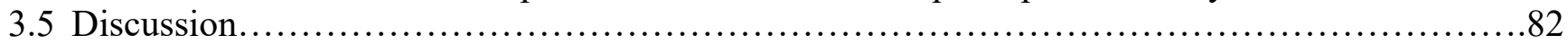

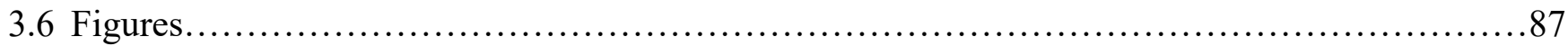

3.6.1 Nalfurafine is a potent $\mathrm{G}$ protein biased KOR agonist........................... 87

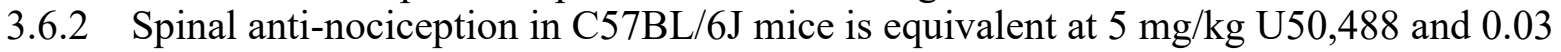

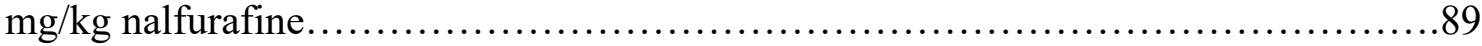

3.6.3 Nalfurafine potentiates morphine-induced supraspinal analgesia in C57BL/6J mice....91

3.6.4 Nalfurafine treatment suppresses both spontaneous and morphine-induced Locomotion...........................................................92

3.6.5 Nalfurafine produces conditioned place aversion (CPA) in C57BL/6J mice at doses that do not reduce morphine-induced CPP.......................................93

3.6.6 Nalfurafine, like the conventional KOR agonist U50,488, reduces morphine-induced conditioned place preference (CPP) in C57BL/6J micem.........................95

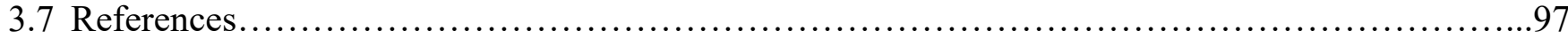

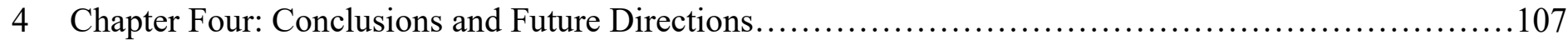

4.1 SNPs identified in West Virginian population of patients with OUD..........................107

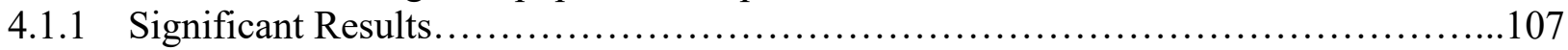

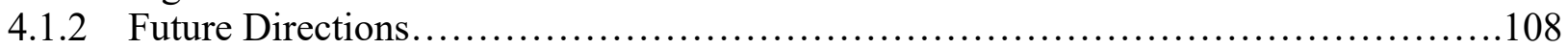

4.2 Preclinical assessment of $\mathrm{G}$ protein-biased KOR agonists.................................... 109

4.2.1 Significant Results................................................... 109

4.2.2 Future Directions............................................................. 
$\underline{\text { List of Tables }}$

Table. Title:

2.6.1 Table 1. Genetic markers and minor allele frequency (MAF) data obtained from public databases (1000 Genomes Project and/or ExAc) and WVU COAT clinic patients

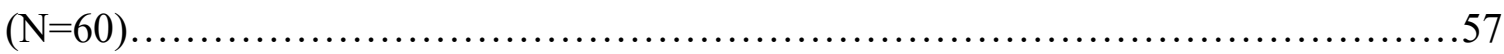




\section{$\underline{\text { List of Figures }}$}

Fig. Title:

1.3.2b.1 Localization of KOR receptors in mesolimbic pathway............................13

1.4.2b.1 Therapeutic potential of G protein-biased KOR agonists...........................21

Nalfurafine is a potent $\mathrm{G}$ protein-biased KOR agonist..............................87

3.6.2 Spinal anti-nociception in C57BL/6J mice is equivalent at $5 \mathrm{mg} / \mathrm{kg}$ U50,488 and 0.03

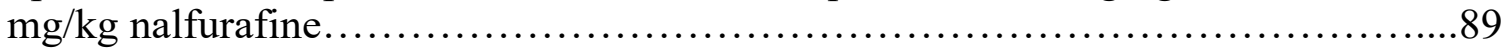

3.6.3 Nalfurafine potentiates morphine-induced supraspinal analgesia in C57BL/6J mice....................................................................

3.6.4 Nalfurafine treatment suppresses both spontaneous and morphine-induced locomotion........................................................... 92

3.6.5 Nalfurafine produces conditioned place aversion (CPA) in C57BL/6J mice at doses that

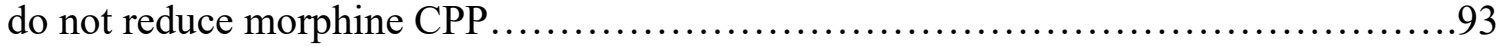

3.6.6 Nalfurafine, like the conventional KOR agonist U50,488, reduces morphine-induced conditioned place preference (CPP) in C57BL/6J mice......................... 95 


\section{$\underline{\text { Abbreviations }}$}

$\begin{array}{ll}\text { 5HT } & \text { Serotonin } \\ \text { ACC } & \text { Anterior Cingulate Cortex } \\ \text { ANOVA } & \text { Analysis of Variance } \\ \text { cAMP } & \text { Cyclic Adenosine Monophosphate } \\ \text { COAT } & \text { Comprehensive Opioid Addiction Treatment } \\ \text { CPA } & \text { Conditioned Place Aversion } \\ \text { CPP } & \text { Conditioned Place Preference } \\ \text { CREB } & \text { Cyclic-AMP Response Element Binding Protein } \\ \text { CRF } & \text { Corticotropin Releasing Factor } \\ \text { DMSO } & \text { Dimethylsulfoxide } \\ \text { DNA } & \text { Deoxyribonucleic Acid } \\ \text { DOR } & \text { Delta Opioid Receptor } \\ \text { EPM } & \text { Elevated Plus Maze } \\ \text { ERK } & \text { Extracellular Signal-Regulated Kinase } \\ \text { FDA } & \text { Food and Drug Administration } \\ \text { FST } & \text { Forced Swim Test } \\ \text { GABA } & \text { Gamma-Aminobutyric Acid } \\ \text { GDP } & \text { Guanosine Diphosphate } \\ \text { GPCR } & \text { G Protein-Coupled Receptor } \\ \text { GRK } & \text { G Protein-Receptor Kinase } \\ \text { GTP } & \text { Guanosine Triphosphate } \\ \text { icv } & \text { Intra-Cerebroventricular } \\ \text { it } & \text { Intra-Thecal } \\ \text { ICSS } & \text { Intra-Cranial Self-Stimulation } \\ \text { JNK } & \text { c-Jun N-Terminal Kinase } \\ \text { KO } & \text { Knockout } \\ \text { KOR } & \text { kappa Opioid Receptor } \\ \text { MAPK } & \text { Mitogen-Activated Protein Kinase } \\ \text { MAT } & \text { Medication Assisted Treatment } \\ \text { MDMA } & \text { Methylenedioxymethamphetamine } \\ \text { MOR } & \text { mu Opioid Receptor } \\ \text { NAc } & \text { Nucleus Accumbens } \\ \text { NIDA } & \text { National Institute on Drug Abuse } \\ \text { norBNI } & \text { nor-Binaltorphimine } \\ \text { OUD } & \text { opioid use disorder } \\ \text { PAG } & \text { Periaqueductal Gray } \\ \text { PAS } & \text { Photobeam Activated System } \\ \text { PDYN } & \text { Prodynorphin } \\ \text { RVM } & \text { Rostral Ventromedial Medulla } \\ \text { SERT } & \text { Serotonin Transporter } \\ \text { SNP } & \text { Single Nucleotide Polymorphism } \\ \text { SUD } & \text { Substance Use Disorder } \\ \text { VTA } & \text { Ventral Tegmental Area } \\ & \end{array}$




\section{Chapter One}

\section{1 - Introduction}

\section{1 - A Brief History of the Opioid Epidemic}

Opium, an extract of the poppy plant, has left its mark on human culture since the plant's first recorded cultivation by the people of Sumeria in 3400 BCE (Rosenblum et al., 2008). As a powerful analgesic producing feelings of euphoria, it was used both medicinally and recreationally (Rosenblum et al., 2008) In the early 1800's Friedrich Serturner isolated morphine, one of the active chemicals in opium (Wilkerson et al., 2016). Morphine saw extensive use during the American Civil War, with subsequent morphine addition developing consistently enough that it earned the name "the army disease" (Courtwright, 1978).Not long afterward began the pursuit of a non-addictive substitute for morphine, with Charles Wright's synthesis of diacetylmorphine (Wilkerson et al., 2016). Today, diacetylmorphine is an illicit drug more commonly known as heroin and used by nearly 1 million people as reported in the 2016 National Survey on Drug Use and Health. Without a nonaddictive replacement, opioid analgesics were largely avoided outside of acute and cancer-related pain until the 1980s, when a pair of publications claimed to demonstrate little risk of addiction when prescribed to pain patients without a history of drug abuse (Porter and Jick, 1980; Portenoy and Foley, 1986; Wilkerson et al., 2016). As a result, prescribing practices loosened and by the end of the 1990 s pain was seen as "the fifth vital sign," with the management of chronic pain even becoming part of the accreditation process for hospitals (Phillips, 2000). Released in 1996, OxyContin ${ }^{\circledR}$ (extended release oxycodone) constituted a major portion of the increase in opioid prescriptions. The extended release formulation, aggressively marketed as less likely to produce addiction, was easily circumvented allowing for large, instant release doses of oxycodone (Remillard et al., 2019) and many consider OxyContin to be a central player in the rise of opioid addiction (Dyer, 2014; Jones et al., 2017). In 2017, the number of opioid prescriptions neared 200 million (CDC, 2017), while the number of opioid use disorder (OUD) diagnoses exceeded 2.1 million (SAMHSA, 2018).

Opioid use disorder is defined in the $5^{\text {th }}$ edition of the Diagnostic and Statistical Manual of Mental Disorders (DSM-V) as the "...compulsive, prolonged self-administration..." of opioid drugs without a 
legitimate medical purpose, or at higher doses than therapeutically required, despite "...clinically significant impairment or distress." While this diagnosis is commonly thought of as addiction to the illicit drug heroin, roughly 1.67 million of the 2.1 million Americans diagnosed with OUD were using prescription opioids (SAMHSA, 2018). While the use of prescription opioids for the treatment of moderate to severe acute and cancer-related pain is regarded as standard and necessary (WHO, 1996; Christo and Mazloomdoost, 2008), their use in the management of chronic pain is contentious (Rosenblum et al., 2008; Salsitz, 2016).

Ironically, these long term outpatient prescriptions of opioids for chronic pain constitute the majority of the increase in opioid prescriptions (Boudreau et al., 2009; Gomes et al., 2011) and carry with them an increased potential for abuse (Shah et al., 2017; Barry et al., 2018; Brat et al., 2018). It is estimated that approximately $8-12 \%$ of patients on long term opioid therapy for chronic pain will develop OUD (Martell et al., 2007; Vowles et al., 2015; Volkow and McLellan, 2016) while closer to $25 \%$ will engage in "aberrant medication-taking behaviors" such as diversion of the medication to other individuals (Martell et al., 2007; Vowles et al., 2015; Volkow and McLellan, 2016). Addiction to and misuse of these prescription opioids is also linked to the use of heroin, with $80 \%$ of new heroin addicts reporting first abusing prescription opioids (Jones, 2013b). With such a strong correlation to prescription rates, it is hoped that alterations in prescribing practices will help curb the rise of OUD (Volkow and McLellan, 2016). A better understanding, however, of why some prove more susceptible than others to opioid abuse will be needed to inform truly responsible and effective prescribing guidelines.

\section{2 - The Genetics of Opioid Addiction}

Extensive investigation is underway to identify single-nucleotide polymorphisms (SNPs) that predict an individual's likelihood of developing a substance use disorder (SUD) of any kind, including OUD. Currently, physicians do no better than chance at predicting which patients abuse opioids (Blum et al., 2018a) and current prescribing guidelines focus on generally reducing exposure and screening for a history of substance abuse (CDC, 2018). A better understanding of the genetics underlying OUD may lead to a standardized method of 
screening patients before initiating opioid therapy to assess their likelihood of abuse and to tailor treatment for greatest efficacy. The genetics of SUD and psychiatric disorders in general, however, is complicated and now accepted to involve many genes, environmental factors, and gene $\mathrm{x}$ environment interactions. The Harvard Twin Study of Substance Abuse found that $34 \%$ of the variance in all substance abuse was attributable to additive genetic effects and that $43 \%$ of the variance in opioid abuse specifically was accounted for by additive genetic effects (Tsuang et al., 1998). This result is supported by at least one other twin study showing 48\% genetic association of opioid addiction (Kendler et al., 2003).Though still in its nascency, ongoing research has identified several SNPs, found largely within genes expressed in limbic circuits, that correlate with rates of OUD and (in some combination) may account for this relationship.

\subsection{1 - mu opioid receptor (MOR)}

Of the predominant opioid receptors (mu, delta and kappa), MOR, encoded by the gene OPRM1 is the primary site of action for opioid analgesics (Basbaum and Fields, 1984a; Pasternak, 1993) and is thus a likely site of variability in response to this class of drugs. Bond et al. identified the A118G SNP of the OPRM1 gene (rs1799971) as having decreased expression and a greater affinity for its endogenous ligand, $\boldsymbol{\beta}$-endorphin (Bond et al., 1998). In addition, Zhang et al. showed a reduced abundance of $\mathrm{G}$ allele mRNA in eight postmortem samples from subjects heterozygous for the A118G SNP, as well as reduced mRNA and protein levels in transfected Chinese Hamster Ovarian (CHO) (Zhang et al., 2005b). Human subjects carrying rs 1799971 have shown increased odds for heroin addiction (Bart et al., 2004), increased nociceptive sensitivity (Tan et al., 2009), and decreased sensitivity to the analgesic effects of opioids in a post-operative setting (Chou et al., 2006). A meta-analysis by Haerian and Haerian of 13 studies with more than 9,000 subjects, however, identified no increased risk of opioid dependence among Caucasian or African-American subjects but an increased risk in Asian subjects with this specific SNP (Haerian and Haerian, 2013). While the A118G SNP remains the most

well studied, other polymorphisms of MOR demonstrate significant associations with various parameters of OUD. The G-to-A transition of OPRM1 SNP rs9479757 correlated with decreased severity of heroin addiction 
in a Han Chinese population (Xu et al., 2014), while SNPs rs510769 and rs3778151 in Caucasians (Levran et al., 2008), along with rs62638690 in people of European ancestry (Clarke et al., 2013), all affect susceptibility to heroin addiction. These results support further investigation of MOR polymorphisms as drivers of susceptibility to OUD

\subsection{2 - kappa opioid receptor (KOR)}

The kappa opioid receptor, encoded by the gene $O P R K 1$, plays a strong role in the regulation of negative affective states (see section on MOR, KOR and Addiction below) and its endogenous ligand, dynorphin, is increased after exposure to opioid drugs (Wang et al., 1999). The OPRK1 SNP rs6473797 demonstrated a reduced risk of heroin addiction in Caucasians (Levran et al., 2008) while Yuferov and Kreek showed that the G36T transition of rs6473797 correlates with a higher susceptibility to heroin addiction in a mixed population (Yuferov et al., 2004). Evidence exists that at least one polymorphism in OPRK1, rs16918875, may increase the risk of heroin addiction in patients who also possess the A118G SNP of OPRM1 beyond that conferred by either SNP alone (Kumar et al., 2012), hinting at a complex interplay of genetic susceptibilities underlying OUD. Various SNPs have also been identified in the gene encoding prodynorphin, the precursor of the endogenous KOR agonist dynorphin, PDYN. The majority of these PDYN SNPs, such as rs35286281 (Wei et al., 2011) and rs 1022563 (Clarke et al., 2012), result in decreased expression of PDYN mRNA, as assessed both in vitro and in post-mortem analysis of human samples (Yuferov et al., 2004). These genetic variations in both OPRK1 and the gene encoding its cognate agonist, $P D Y N$, demonstrate the potential importance of this KOR signaling system in the development of addiction and thus is examined further in later sections.

\subsection{3 - Delta Opioid Receptor (DOR)}

Encoded by the gene $O P R D 1$, the delta opioid receptor has been the subject of fewer studies identifying polymorphisms in human subjects with OUD, although preclinical data do support a role for DOR signaling in altering the rewarding properties of MOR targeting analgesics (Suzuki et al., 1996; Shippenberg et al., 2009). Two independent groups demonstrated correlations between OPRD1 SNPs rs3766951 and rs2236857 and 
heroin addiction in Caucasians (Levran et al., 2008; Nelson et al., 2014) while a third group found a correlation between OPRD1 SNP rs508448 and earlier age of heroin use in a population of Han Chinese (Gao et al., 2017). These initial population studies, along with the available preclinical evidence, support further investigation into variations in OPRD1 and their relationships to the development of OUD.

\subsection{4 - Serotonin Receptors (5HTR)}

The serotonin (5-hydroxytryptamine) receptors are a large group, with 14 distinct receptors from seven different families (Barnes and Sharp, 1999); variations in the genes HTR1B, HTR2A and HTR3A/B (encoding the $5-\mathrm{HT}_{1 \mathrm{~B}}, 5-\mathrm{HT}_{2 \mathrm{~A}}$, and $5-\mathrm{HT}_{3}$ receptors respectively) have shown correlations with heroin addiction. The $\mathrm{G}$ allele of the G861C variant of HTR1B (rs6296) correlated with heroin addiction, as well as amount of heroininjection, in a study of a Han Chinese population (Gao et al., 2011), while a meta-analysis of studies assessing HTR1B SNPs for relationships with substance abuse found that rs130058 significantly correlated with heroin dependence in a mixed population (Cao et al., 2013). The A allele of the A1438G polymorphism (rs6311) of HTR2A correlates with heroin dependence in one study of a population in Spain (Saiz et al., 2008), while SNPs within HTR3B (rs3758987) (Levran et al., 2008) and HTR3A (rs1176724 and rs897687) (Levran et al., 2009) show correlations with heroin addiction in Caucasian and African-American populations, respectively. Although all these reports involve serotonin receptors, their individual biological functions vary significantly, and thus further research is needed to elucidate the role of each of these polymorphisms in increasing susceptibility to OUD.

Taken together, the studies outlined above support the genetic association seen in OUD, while at the same time make obvious the nascency of this line of research. Such factors as patient stratification, statistical analysis and lack of replication make it difficult to draw strong conclusions from the present reports. These findings, however, along with future advances in both genetic and epidemiologic methods, should encourage further efforts to identify predictive genetic factors for OUD. 


\section{3 - MOR, KOR, and Addiction}

The opioid family of neuron signaling-inhibitory G protein-coupled receptors (GPCRs) not only includes the "classical" mu, kappa, and delta opioid receptors, but also the "non-classical" Nociceptin receptor. While all have been shown to modulate certain aspects of opioid-induced behaviors in rodent studies, MOR and KOR are thought to exhibit the strongest influence on the development of addiction (Koob and Le Moal, 1997; Crowley and Kash, 2015; Chavkin and Koob, 2016; Koob and Volkow, 2016). Opioid painkillers target primarily the mu opioid receptor, agonism of which produces both analgesia and euphoria (Koob and Le Moal, 1997; Koob and Volkow, 2016). Activation of the kappa opioid receptor produces analgesia as well (albeit more weakly), and carries with it clinically limiting effects, such as dysphoria and psychotomimesis (Pfeiffer et al., 1986; Siebert, 1994; Greenwald and Stitzer, 1998; Kivell and Prisinzano, 2010). The following sections outline the neurobiology of each of these opioid receptors as they relate to analgesia as well as the development and maintenance of opioid addiction.

\subsection{1 - Analgesia}

The clinical success of MOR-targeting analgesics arose from their activity at both spinal and supraspinal sites. At the level of the spinal cord, MOR localizes to both the presynaptic terminal of primary nociceptive afferents transmitting pain signals into the spinal cord (Fields and Basbaum, 1978; Pasternak, 1981; Moriwaki et al., 1996; Kline and Wiley, 2008; Todd, 2010b), as well as the post-synaptic cell bodies of secondary nociceptive efferents transmitting pain signals to higher brain centers (Moriwaki et al., 1996; Kline and Wiley, 2008; Todd, 2010b). MOR activation also modulates pain signals through its activity in the periaqueductal gray (PAG) matter (Basbaum and Fields, 1978; Yaksh et al., 1980; Basbaum and Fields, 1984b; Ghelardini et al., 2015b), a midbrain region that controls numerous functions, from fear and anxiety responses to blood pressure (Basbaum and Fields, 1978; Yaksh et al., 1980; Basbaum and Fields, 1984b; Behbehani, 1995; Ghelardini et al., 2015b). 
The PAG modulates pain by controlling projections from midbrain nuclei to the dorsal horn of the spinal cord, a descending pathway that inhibits nociception (Basbaum and Fields, 1978; Yaksh et al., 1980; Basbaum and Fields, 1984b; Behbehani, 1995; Ghelardini et al., 2015b). This pathway begins in the periaqueductal gray, where glutamatergic neurons projecting to serotonergic and noradrenergic cell bodies in the rostral ventromedial medulla (RVM) (Basbaum and Fields, 1978; Yaksh et al., 1980; Basbaum and Fields, 1984b; Behbehani, 1995; Ghelardini et al., 2015b) remain under tonic inhibition by a local GABAergic circuit (Basbaum and Fields, 1978; Yaksh et al., 1980; Basbaum and Fields, 1984b; Behbehani, 1995; Ghelardini et al., 2015b). Activation of MORs located on the GABAergic neurons of the PAG leads to disinhibition of the glutamatergic projection neurons, in turn stimulating the serotonergic and noradrenergic neurons of the RVM (Pasternak, 2005b; Ghelardini et al., 2015b). These RVM neurons then project to the dorsal horn of the spinal cord, wherein release of serotonin and norepinephrine inhibit transmission of nociceptive signals (Pasternak, 2005b; Ghelardini et al., 2015b). In this way, MOR-targeting analgesics prevent the transmission of nociceptive signals directly, through actions at receptors in the dorsal horn, and indirectly through the modulation of regulatory projections.

The role of KOR signaling in producing spinal analgesia is similar to MOR activation outcomes, as the distribution of KOR resembles that of MOR (Besse et al., 1990; Todd, 2010b; Stein, 2016b) and KOR activation serves to inhibit the transmission of nociceptive signals through the dorsal horn (Todd, 2010a; Stein, 2016a). In the PAG and descending pain-inhibitory circuit, however, the role of KOR remains unclear. For example, one study found that microinjection of pentazocine, a KOR agonist, into the PAG produced analgesia against noxious heat but not against pressure, while fentanyl, a MOR-selective agonist, produced analgesia against both pain modalities (Llewelyn et al., 1983). A second group, however, used a thermal stimulus to show that morphine (a MOR-selective agonist), but not U50,488 (a KOR-selective agonist), produced an analgesic effect when microinjected directly into the PAG (Llewelyn et al., 1983). In addition to being a KOR agonist, pentazocine also acts as a partial agonist of MOR, while U50,488 acts more selectively at KOR and not MOR 
(Clark and Pasternak, 1988; Hoskin and Hanks, 1991). This difference likely explains the disparate results between these two studies.

As a further complication, the distribution of MOR and KOR in these descending circuits remains unclear. While overlap may exist in their distribution, as reported in some histological studies (Gutstein et al., 1998), others demonstrate that MOR and KOR act in specific subpopulations of neurons in the RVM (Pan et al., 1997; Winkler et al., 2006), and that this distribution produces opposing analgesic effects (Pan et al., 1997; Tershner et al., 2000; Bie and Pan, 2003) (discussed further below). These discrepancies may also contribute to reported differences regarding receptor signaling effects on particular pain modalities. While less potent for somatic pain, KOR agonists display a greater potency for visceral pain in both preclinical studies (Su et al., 2002; Kamp et al., 2003) and in a clinical trial using a peripherally restricted KOR agonist (Arendt-Nielsen et al., 2009). As the underlying mechanisms and circuitry of somatic and visceral pain differ (Cervero and Laird, 1999), it is possible that these ambiguities in the distribution of each receptor play a role in their differing effects.

Finally, the variable of sex plays a large role in opioid analgesia. While it was long held that opioid analgesics produced greater analgesia in human females (Miaskowski and Levine, 1999), more recent studies complicate the issue, showing not only a greater degree of opioid-induced analgesia in males than in females, but also that these results vary depending on the opioid analgesic used, the type of pain, and the method used to assess pain/opioid efficacy (Gourlay et al., 1988; Cepeda and Carr, 2003; Miller and Ernst, 2004; Fillingim et al., 2005; Sibille et al., 2011; Lee and Ho, 2013). A 2010 meta-analysis of fifty studies found no association between sex and analgesia, although sub-group analysis found greater morphine-induced analgesia in women (Niesters et al., 2010). Studies of KOR-agonist induced analgesia produce the most reliable findings, repeatedly demonstrating greater analgesic efficacy in human females compared with males (Gear et al., 1996; Fillingim and Gear, 2004; Miller and Ernst, 2004). As a further complication, results from preclinical experiments on rats and mice show that both MOR-targeting and KOR-targeting opioid analgesics prove more efficacious in males than females (Lee and Ho, 2013; Abraham et al., 2018). 
While both MOR and KOR produce analgesia through their activities in the spinal cord and descending pain-modulatory pathways, MOR agonists provide greater analgesia than KOR agonists due to their functional divergence in higher brain centers. Compared with KOR agonists, MOR-targeting analgesics retain broad applicability to nearly all types of pain, in part because of their ability to produce euphoria, thereby reducing the affective component of pain and preventing "agony" even when the conscious perception of a nociceptive stimulus remains (Zubieta et al., 2005; Porreca and Navratilova, 2017a). This ability, however, also leads to the dramatic abuse potential of MOR-targeting analgesics. In contrast, KOR agonism produces anxiety and dysphoria, limiting the clinical utility of KOR agonists and playing a major role in the cycle of addiction through its role in the production of negative affect. The following sections explore the effects of MOR and KOR agonism on affective state and motivation with respect to the development of addiction.

\subsection{2 - Euphoria and Dysphoria}

Both mu and kappa opioid receptors play central roles in the cycle of addiction. While MOR activation figures prominently in the initial development of drug preference through its euphorigenic properties (Koob and Le Moal, 1997; Koob and Volkow, 2016), KOR activation reinforces habitual drug taking through its dysphoric properties, producing a state of negative affect and "emotional pain" (Koob and Le Moal, 1997; Bruchas et al., 2010; Koob, 2013). In the CNS, these two receptors normally function in opposition to produce an affective homeostasis. When perturbed, however, this system may spiral to lower and lower set-points, leading to the destructive cycle of drug seeking known as addiction.

\subsection{2a - Euphoria, reward and the mu opioid receptor}

While MOR expression is distributed widely throughout the brain, the highest levels of MOR expression are found in regions involved in pain processing (notably the thalamus and periaqueductal gray matter) and motivated behavior (the mesolimbic system) (Le Merrer et al., 2009), with the latter playing the strongest role in the development of addiction. The endogenous ligand of the mu opioid receptor, $\beta$-endorphin, is produced in 
the hypothalamus as well as the nucleus tractus solitarius (Froehlich, 1997), and is distributed throughout the brain as a homeostatic mechanism of reducing stress and producing reward, being released in response to novel stimuli as well as in times of stress and exercise (Rubinstein et al., 1996; Goldfarb and Jamurtas, 1997; Veening and Barendregt, 2015). As such, the mu opioid receptor system largely produces a positive affective response and motivates behavior through its effects on the mesolimbic system.

The mesolimbic pathway comprises dopaminergic projections from the ventral tegmental area (VTA) to the nucleus accumbens (NAc) and plays a key role in reward prediction, in addition to encoding the incentive salience of natural rewarding stimuli (Fields and Margolis, 2015). When encountering a rewarding stimulus, ranging from basic rewards like food to complex social rewards such as praise, burst firing of the VTA releases dopamine in the NAc and produces a positive reinforcement of the behavioral pattern that produced the rewarding stimulus (Bromberg-Martin et al., 2010; Salamone and Correa, 2012). VTA dopamine neurons remain under tonic inhibition by local GABAergic interneurons that express mu opioid receptors (Leone et al., 1991; Johnson and North, 1992). Endogenous opioid release in this area serves to inhibit these GABAergic interneurons, leading to disinhibition of VTA dopaminergic projections to the NAc, producing positive reinforcement (Leone et al., 1991; Johnson and North, 1992). Strong evidence supports this action on VTA mu opioid receptors as the primary mechanism of opioid analgesic induced reward (Leone et al., 1991; Fields and Margolis, 2015; Valentino and Volkow, 2018). Place preference for MOR-targeting analgesics is blocked in rats by administration of a MOR antagonist directly into the VTA (Olmstead and Franklin, 1997); conversely, MOR agonists are self-administered by rats when applied directly to the VTA (Bozarth and Wise, 1981; Zangen et al., 2002). While animals will self-administer MOR agonists applied to several other brain regions as well (David and Cazala, 1994), their actions in the VTA are widely regarded as necessary and sufficient for the reinforcing properties of opioid analgesics (Fields and Margolis, 2015). Furthermore, disinhibition of dopamine release likely plays a role in the ability of MOR-targeting opioid analgesics to reduce the affective experience of pain, as decreased function of midbrain dopaminergic neurons leads to increased pain (Saadé et al., 1997; Sophie and Ford, 2012), while dopaminergic agents can produce analgesia themselves . Mice lacking tyrosine hydroxylase 
(dopamine deficient mice) show reduced thermal nociception in the tail withdrawal assay in response to morphine, supporting the role of dopaminergic signaling in the analgesic response to traditional opioid analgesics (Hnasko et al., 2005).

This canonical model, however, is not without its complications. Destruction of dopaminergic projections from the VTA to the anterior cingulate cortex (ACC), for example, blocks the acquisition of place preference to morphine administered to rodents systemically as well as directly into the VTA, implicating mesocortical circuitry in opioid reinforcement (Narita et al., 2010). In addition, while dopamine antagonists may block acquisition of morphine-induced place preference, the potency of this effect varies with the specificity of the antagonist for the various subtypes of dopamine receptor (Manzanedo et al., 2001). More

confounding still are findings dopamine deficient mice (lacking functional tyrosine hydroxylase) still display a place preference to morphine (Hnasko et al., 2005), implicating factors beyond dopaminergic signaling in producing opioid reward.

While the intricacies of dopamine signaling in addiction require further inquiry, the initial phase of the development of opioid addiction -- acute reward and euphoria -- remain best explained by disinhibition of mesolimbic circuitry. The ability of opioid analgesics to potently disinhibit this circuitry underpins both their profound analgesic potential and their devastating propensity to incentivize compulsive use. As such a powerful circuit, the brain employs potent means of regulation, none linked more tightly to the cycle of addiction than the kappa opioid receptor.

\subsection{2b - Dysphoria, altered set-points and the kappa opioid receptor}

While the distribution of kappa opioid receptors mirrors that of MOR in many regions, oppositional localization in specific regions produces profound differences in the effect of KOR stimulation (Le Merrer et al., 2009). While stimulation of MORs produces euphoria, activation of KORs produces dysphoria, a negative affective state that includes components of anxiety, anhedonia, and depressive symptoms (Knoll and Carlezon, 2010; Lalanne et al., 2014; Crowley and Kash, 2015). 
Dynorphin, a neuropeptide cleaved to six different lengths from the precursor prodynorphin and the endogenous ligand of the kappa opioid receptor, is produced in the hypothalamus (Froehlich, 1997), the amygdala (Marchant et al., 2007), and direct pathway GABAergic medium spiny neurons of the striatum (Steiner and Gerfen, 1998) (among other regions), and is released in response to stress (Knoll and Carlezon, 2010). Unlike $\beta$-endorphin, however, dynorphin plays the role of a negative homeostatic regulator. Dynorphin produces the negative experiences of stress (Land et al., 2008) and plays a role in mediating the central effects of corticotropin releasing factor (CRF), a major hormonal regulator of the stress response (Land et al., 2008). The areas most heavily implicated in the production of this negative state include the VTA-to-NAc circuit, along with the amygdala and dorsal raphe nucleus (DRN), the latter being the major serotonergic nucleus of the brain (Luo et al., 2015). In each of these regions, activation of KOR produces effects largely in opposition to those of MOR, culminating in the overall negative affective state of dysphoria.

In the mesolimbic system, KOR activation functions to reduce dopamine release, with KOR expression found on both the cell bodies of dopaminergic VTA neurons, as well as the presynaptic terminals of these

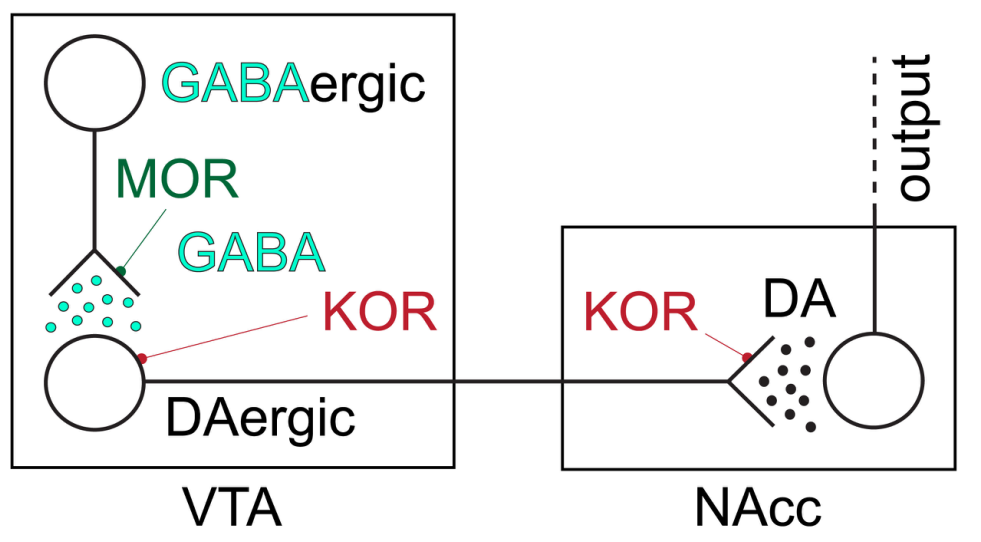

Figure 1.3.2b.1. Schematic of KOR and MOR receptors in mesolimbic pathway. Activation of MORs on GABAergic interneurons of the VTA disinhibits dopamine release, producing reward. Activation of KORs on dopaminergic neurons inhibits dopamine release, producing dysphoria.

neurons within the NAc (Figure 1) (Svingos et al., 2001; Chefer et al., 2013; Ehrich et al., 2015a). In both these 
regions, KOR activation acts as negative feedback regulation on mesolimbic dopamine release, serving to restore homeostatic function within this circuit. When dopamine D1 receptor (D1R)-expressing neurons within the NAc are stimulated by dopamine, they release both dynorphin and GABA from axonal projections terminating in the VTA to reduce the firing rate of the dopaminergic neurons located therein (Nestler and Carlezon, 2006; Mysels and Sullivan, 2009). As disinhibition of this circuitry by MOR agonists produces a rewarding stimulus, inhibition by KOR agonists produces the opposite (i.e., aversion, as measured in rodents in the conditioned place aversion (CPA) paradigm (Chefer et al., 2013; Ehrich et al., 2015a)); as a result, KOR agonists do not support self-administration in rats or rhesus monkeys (Tang and Collins, 1985; Serra et al., 2015; Ruan et al., 2016). Recent studies have strongly linked these aversive properties of KOR agonists to actions on mesolimbic dopamine neurons (Chefer et al., 2013; Ehrich et al., 2015a).

KOR actions in the amygdala appear to play a role in modulation of fear and anxiety related behaviors, possibly through modulation of local GABAergic neurotransmission and long-term potentiation (Huge et al., 2009; Kang-Park et al., 2013; Gilpin et al., 2014). Fear conditioning in rats is reported to increase OPRK1 mRNA in this region, and local inhibition of KORs reduces this response (Knoll et al., 2011). In addition, KOR antagonism in the amygdala blocks the anxiogenic effect of a natural stressor (repeated forced swim stress) or intra-amygdalar injection of CRF in the elevated plus maze (EPM) assay (Bruchas et al., 2009). The DRN also plays a central role in mediating the affective response to KOR agonists. Stimulation of KORs in this region reduces extracellular serotonin concentration (Tao and Auerbach, 2005), likely through increasing surface levels of the serotonin transporter (SERT) via a p38 $\alpha$ MAPK dependent mechanism (Bruchas et al., 2011), an effect seen in mice after both local administration of a KOR agonist and social defeat stress (Bruchas et al., 2011). Furthermore, while the KOR agonist U50,488H did not produce a place aversion in mice lacking the kappa opioid receptor, viral re-expression of KORs on DRN neurons projecting to the NAc restored the effect in these KOR knockout mice (Land et al., 2009a).

The effects of KORs within these specific brain regions support the view that the dynorphin/KOR system plays a central role in mediating the aversive effects of stress (Land et al., 2009a; Bruchas et al., 2010; 
Chavkin and Koob, 2016). Dynorphin levels increase due to stress (Nabeshima et al., 1992), and blockade or genetic deletion of OPRK1 in mice prevents the pro-depressive and anxiogenic effects of forced swim, social defeat, and foot-shock stressors (Mague et al., 2003; Land et al., 2008; Bruchas et al., 2009; Bruchas et al., 2011). Systemic administration to rodents of KOR agonists produces a place aversion (Zhang et al., 2005a; Chefer et al., 2013) and depressive-like phenotypes in the forced swim and intra-cranial self-stimulation (ICSS) assays (Todtenkopf et al., 2004; Carlezon et al., 2006; Brust et al., 2016b). By producing these negative affective states, the dynorphin/KOR system also figures heavily into the addictive cycle. Stressful stimuli reinstate extinguished drug seeking behaviors in both place preference and self-administration paradigms (Mantsch et al., 2016). Pre-treatment of mice with the KOR antagonist nor-binaltorphimine (norBNI), as well as genetic deletion of either OPRK1 or PDYN, prevented the reinstatement of cocaine conditioned place preference (CPP) by foot shock or forced swim stressors, as well as to a single administration of U50,488H (Redila and Chavkin, 2008). In addition, CPP for cocaine increased in mice exposed to forced swim stress prior to conditioning, an effect blocked by pre-treatment with norBNI (McLaughlin et al., 2003). While KOR antagonism also reduced ethanol self-administration by rats (Walker and Koob, 2008), the applicability to other drugs of abuse requires further investigation.

In light of its role in regulating limbic function and mediating stress responses, the kappa opioid receptor should be viewed as a key component of the "Allostatic Model" of addiction (Koob and Le Moal, 2001; Koob and Schulkin, 2018). This model contextualizes the state of addiction as one of a pathologically altered homeostatic set point, or "allostasis" (McEwen, 1998; Koob, 2008). The dynorphin/KOR system contributes to this allostatic response largely through modulation of dopamine tone within the mesolimbic system (Bruchas et al., 2010; Koob, 2013). As described above, MOR-targeting analgesics increase dopaminergic tone in the NAc, a property common to nearly all drugs of abuse (Wise, 2009; Koob and Volkow, 2016). Repeated use results in increased production of cAMP response element binding protein (CREB) within the NAc (Carlezon et al., 2005; Nestler and Carlezon, 2006) and subsequent upregulation of dynorphin and increased dynorphin tone (Nestler and Carlezon, 2006; Mysels and Sullivan, 2009; Bruchas et al., 2010). With cessation of opioid use, this 
elevated dynorphin tone leads to a state of dysphoria, increasing the hedonic valence of the drug and increasing the susceptibility of relapse in an attempt to attain the now pathologically altered homeostatic set point (Bruchas et al., 2010; Koob, 2013; Koob and Schulkin, 2018).

In summary, while activation of both mu and kappa opioid receptors produces analgesia in response to stressful stimuli, the psychological functions of the receptors diverge dramatically and represent the opposing faces of opioid addiction. The desire of clinicians to alleviate pain placed the profound effects of MOR stimulation at the forefront of medicine in the early 2000s. Today, KOR antagonists sit among the National Institute of Drug Abuse (NIDA)'s ten most wanted drugs to help end the opioid crisis (Rasmussen et al., 2019), with the thought that the clinical application of KOR antagonism might reduce the contribution of stress, and its molecular and circuitry sequelae, in drug seeking and addiction reinstatement.

\section{4 - Pharmacological approaches for improving opioid analgesics}

The search for a non-addictive opioid analgesic began nearly the moment Friedrich Serturner first isolated morphine in the early 1800's (Wilkerson et al., 2016), and the search regrettably continues today, over 200 years later. Many opioids are sold today as combination drugs, compounding opioids with non-steroidal anti-inflammatories like ibuprofen and acetaminophen as adjuvants meant to reduce the dose of opioids necessary to effectively treat pain, otherwise known as "dose sparing" (Remy, 2005; Maund et al., 2011). Other adjuvant therapies, such as suboxone, focus on preventing improper use of opioid medications by compounding them with opioid antagonists active only when taken through improper routes (Chen et al., 2014), but the effect of these measures are unclear. While many approaches are currently being investigated in labs across the world, from targeting little-understood splice-variants of the mu opioid receptor (Xu et al., 2017) to designing opioids that function only in the presence of inflammation (Spahn et al., 2017), the following sections focus on two widely studied and promising avenues: combination therapies activating multiple opioid receptors, and the development of "biased agonists." 


\subsection{1 - Combining MOR and KOR Activation}

In the 1990s, researchers began investigating the possibility of utilizing the analgesic and nonreinforcing properties of KOR agonists to augment the effects of traditional MOR agonists. While KOR agonists alone proved less potent in producing analgesia (Pizziketti et al., 1985; Briggs et al., 1998), the combination of fentanyl (MOR agonist) with U69593 (KOR agonist) showed additive analgesic effects in rhesus monkeys while also reducing self-administration levels (Negus et al., 2008a). Further studies demonstrated that combined administration of MOR and KOR agonists prevented development of the clinical liabilities of opioid tolerance, hyperalgesia, and respiratory depression (He and Lee, 1997; Verborgh et al., 1997; Black and Trevethick, 1998; Field et al., 1999; Khotib et al., 2004)

While pre-clinical experiments demonstrated the utility of combined agonism of each of these opioid receptors, enthusiasm for this approach waned in the face of early clinical experiments utilizing mixed MOR/KOR active compounds. For example, while nalbuphine (a KOR agonist and MOR partial agonist) demonstrated reduced morphine-induced CPP and enhanced analgesia in pre-clinical studies (Tao et al., 2006), human studies demonstrated dose-dependent increases in dysphoria (Jasinski and Mansky, 1972; Preston et al., 1989a; Walsh and Babalonis, 2017). Also, pentazocine (similar to nalbuphine) and butorphanol (a KOR agonist and MOR antagonist) demonstrated the classic dysphoric effects of traditional KOR-targeting agonists in humans at higher doses (Preston et al., 1987; Zacny et al., 1994; Greenwald and Stitzer, 1998; Walsh et al., 2008; Walsh and Babalonis, 2017), limiting their therapeutic potential.

Of note, however, is one report (Preston and Bigelow, 1993) that co-administration of the opioid receptor antagonist naltrexone with pentazocine in human subjects "unmasks" the KOR-related dysphoric effects of pentazocine at lower doses, but blocks both MOR-dependent and KOR-dependent effects at higher doses. As the antagonist naltrexone possesses greater affinity for mu than kappa opioid receptors, these results of Preston \& Bigelow support the premise that MOR agonism can mitigate KOR-related anti-therapeutic effects to some degree. While a single compound is generally considered a more attractive drug candidate than a dual-drug 
formulation, these studies demonstrate that relative activity at each receptor plays a critical role in the interaction between these two receptor systems. Studies in patients receiving methadone maintenance therapy demonstrate that administration of nalbuphine, pentazocine, or butorphanol can precipitate a withdrawal syndrome (Preston et al., 1988; Preston et al., 1989b; Strain et al., 1993), indicating that none of these three, mixed-action drugs achieves activity at MOR comparable to methadone. While new mixed MOR/KOR drugs under development may possess more favorable activity profiles, such as the orvinols and $6 \beta$ naltrexamines (Cami-Kobeci et al., 2009; Greedy et al., 2013), a co-administration paradigm may allow for greater control over relative activity at each receptor.

With these clinical studies dampening the potential therapeutic implications for KOR agonist development, research efforts dwindled. The rise of opioid addiction rates, however, has reinvigorated interest in the kappa opioid receptor. Cara Therapeutics invested heavily in developing a peripherally restricted KOR agonist, and its novel compound, CR845/difelikefalin is currently in Phase III clinical trials (Cara, 2018). In addition to peripheral restriction of KOR agonism (i.e., to gain analgesic effect without concomitant CNS-centered dysphoric effects), major preclinical research efforts focus on utilizing a relatively new concept in pharmacology known as "biased agonism." This approach utilizes variations in the efficacy of different compounds to engage various aspects of intracellular machinery, designing drugs that differ in their ability to produce canonical effects associated with receptor stimulation.

\subsection{2 - Biased Agonism: All the good and none of the bad?}

G protein-coupled receptors regulate an astoundingly diverse array of physiological processes and represent the target of approximately 37\% of all drugs approved by the FDA as of 2017 (Hauser et al., 2017). Structurally, GPCRs contain seven transmembrane domains that couple to a heterotrimeric complex of G $\alpha, \beta$ and $\gamma$ subunits on the intracellular face (McCudden et al., 2005). The Go subunit of this heterotrimeric complex associates with guanine nucleotide diphosphate (GDP) in the resting (inactive) conformation. When bound by agonist, the activated GPCR catalyzes the exchange of GDP for guanine nucleotide triphosphate (GTP), at 


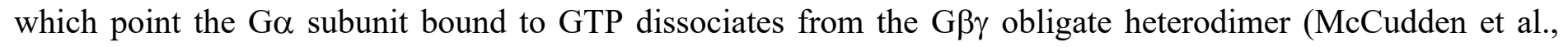
2005). Both the G $\alpha$-GTP and G $\beta \gamma$ complexes initiate signaling cascades that vary depending upon the receptor and cellular context and are considered "G protein dependent" as a whole (McCudden et al., 2005). All opioid receptors couple to the Gai/o class of Ga proteins. (Connor and Christie, 1999; Stein, 2016a). The Gi/o heterotrimeric complex, when activated (and separated) by GTP binding, generally functions to inhibit the production of cyclic adenosine monophosphate (cAMP), as well as increase potassium conductance (hyperpolarizing the cell) and inhibit calcium conductance (preventing vesicular release of neurotransmitters) (Pasternak, 2005a; Al-Hasani and Bruchas, 2011; Ghelardini et al., 2015a). Activation of opioid receptors inhibits neuronal function through these G protein-dependent mechanisms.

In addition to G protein-dependent signaling, work in the 1990's demonstrated that GPCRs also initiate signaling cascades through a class of proteins known as $\beta$-arrestins (Wisler et al., 2014). Canonically, when a

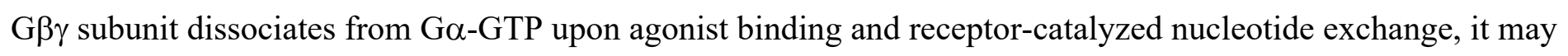
activate a class of proteins known as G protein-receptor kinases (GRKs) (McCudden et al., 2005). This class of proteins serves to phosphorylate activated GPCRs, subsequently leading to the recruitment of $\beta$-arrestin (McCudden et al., 2005; Wisler et al., 2014). One of the functions of $\beta$-arrestin proteins is to act as a molecular brake on GPCR signaling, leading to the cessation of further G protein heterotrimer activation and subsequent receptor internalization. The internalized $\beta$-arrestin/GPCR complex then activates signaling pathways distinct from those activated by G protein subunits (Raehal, 2005; Wisler et al., 2014).

When a GPCR agonist compound activates either the G protein-dependent or $\beta$-arrestin dependent pathway to a greater extent than the other, this agonist is considered "biased" towards that signaling pathway (Wisler et al., 2014). Research in recent years demonstrates that the physiological and behavioral effects classically associated with stimulation of specific GPCRs may occur to a greater or lesser extent upon the application of biased compounds (Raehal, 2005; Ehrich et al., 2015b; Ewald et al., 2017b; Schmid et al., 2017b). The 
possibility of discovering opioid drugs that lack traditional adverse effects has led to a surge in research focused on biased MOR and KOR compounds.

\subsection{2a - G protein-biased MOR agonists}

At the mu opioid receptor, $\mathrm{G}$ protein-dependent signaling produces the intended analgesic response (Todd, 2010a; Stein, 2016a), while $\beta$-arrestin signaling governs many of the unwanted side-effects. As might be predicted by the function of $\beta$-arrestin, mice lacking $B A R R 2$, the gene encoding $\beta$-arrestin 2 , displayed a decrease in the development of opioid analgesic tolerance and prolonged analgesic responses to morphine (Bohn, 1999; Bohn et al., 2000). In addition, BARR2 knockout (KO) mice also display reduced respiratory depression and constipation after morphine administration (Raehal, 2005). Loss of $\beta$-arrestin 2 did not, however, affect the development of naloxone-precipitated withdrawal symptoms (Bohn et al., 2000) or of morphineinduced hypothermia (Bohn, 1999). Pursuit of a G protein-biased MOR agonist led to the development of TRV130 (oliceridine), which shows potent analgesic effects and reduced tolerance development in rodents, yet retains the clinical liability of inhibitory effects on GI motility (Altarifi et al., 2017). Importantly, TRV130 also displays robust reinforcing effects, linking abuse liability to G protein-dependent signaling (Altarifi et al., 2017; Negus and Freeman, 2018). Despite these pre-clinical findings, TRV130 has proceeded to clinical trials as a potent opioid with reduced likelihood of requiring escalating doses due to a decreased propensity to induce tolerance.

A Phase I, double-blind, placebo-controlled study comparing morphine with TRV130 reported that the latter drug exhibited analgesic efficacy with reduced respiratory depression at equianalgesic doses, as well as a lower incidence of severe nausea (Soergel et al., 2014). While the FDA Advisory Committee stated that oliceridine demonstrated a "favorable benefit/risk profile" and proved superior to placebo in both APOLLO-1 and APOLLO-2 Phase III clinical trials (Research, 2018), the Anesthetic and Analgesic Drug Products Advisory Committee did not grant FDA approval to oliceridine, stating that "...oliceridine is a mu opioid agonist with an abuse potential, overdose potential and ability to produce physical dependence that is similar to other mu 
opioid agonists" (FDA, 2018). As stated by this same report, “...it does not appear that the biased agonism of oliceridine with regard to preferential recruitment of G-protein over $\beta$-arrestin2 translates into a human safety advantage..." (FDA, 2018). Although the G protein signaling-biased TRV130 is only the first drug of its kind to undergo FDA review, these statements demonstrate not only the significant focus of the FDA on abuse potential with regard to opioid drugs, but also the difficulties of translating preclinical findings into human subjects.

\subsection{2b - G protein-biased KOR agonists}

At the kappa opioid receptor, G protein-dependent signaling also produces analgesic effects through inhibition of pain transmission through the dorsal horn of the spinal cord (Todd, 2010a; Stein, 2016a). In contrast, a strong arc of research implicates $\beta$-arrestin2 signaling in the therapeutically limiting dysphoric effects of KOR agonists (Bruchas et al., 2006; Bruchas et al., 2007a; Ehrich et al., 2015b). As discussed above, natural stressors such as forced swim, activate kappa opioid receptors in mice. It has been reported that pharmacological inhibition of $\mathrm{p} 38$, a mitogen activated protein kinase (MAPK) downstream of $\beta$-arrestin2 signaling at KOR (Bruchas et al., 2006), with SB203580, or preventing $\beta$-arrestin2 recruitment to activated KOR through gene deletion of the gene encoding the upstream GRK3 (GRK3), prevents the dysphoric component of this stress (Bruchas et al., 2007a). Furthermore, deletion of the gene encoding p38- $\alpha$ (MAPK14) from dopamine neurons prevents conditioned place aversion (CPA) in mice to the unbiased KOR agonist U50,488 (Ehrich et al., 2015b). These results and others have spurred investigation into a "non-dysphoric" replacement of traditional MOR-targeting opioid analgesics with a single KOR agonist biased toward G protein signal transduction. 


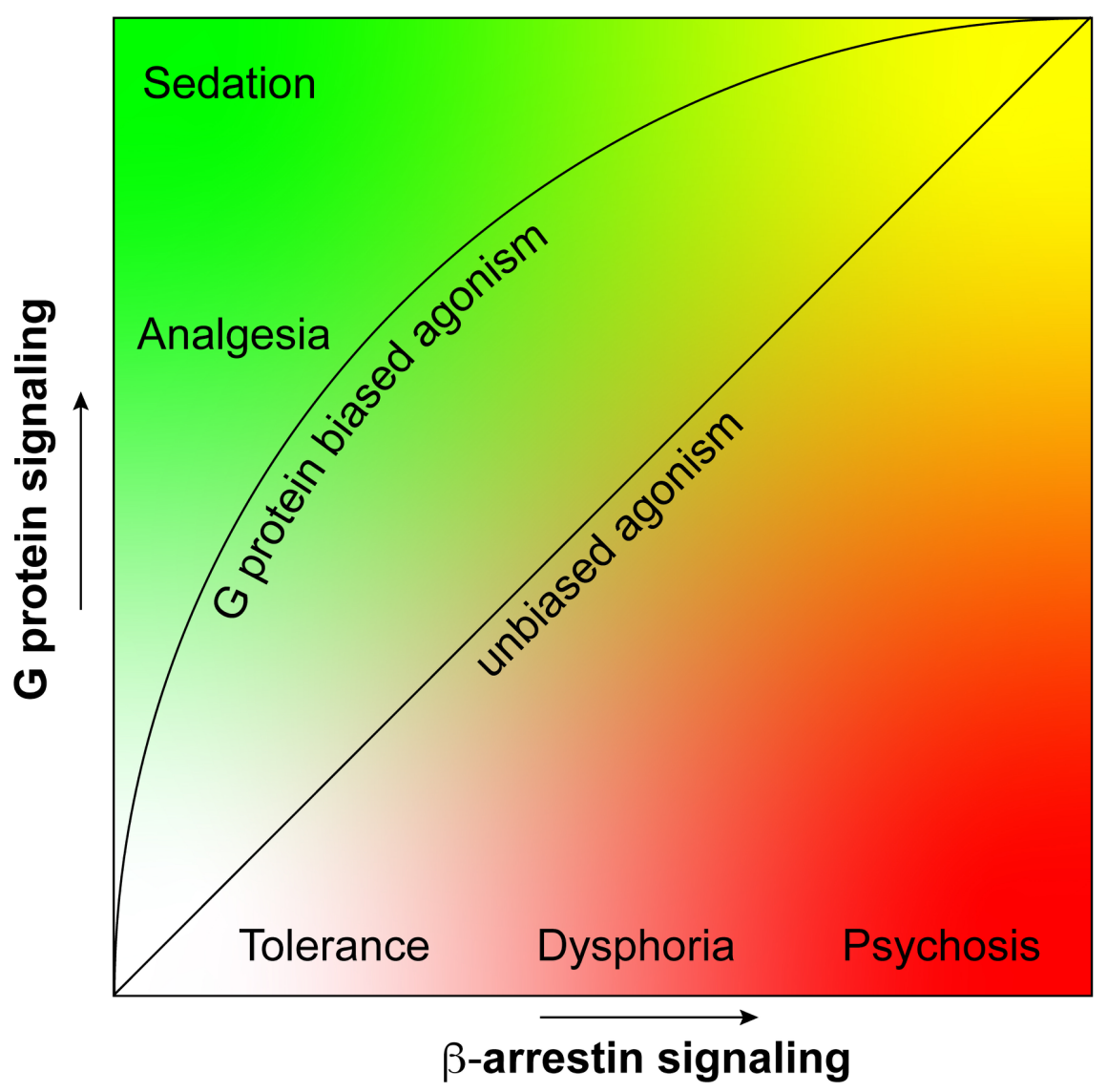

Figure 1.4.2b.1. Therapeutic potential of $G$ protein-biased KOR agonists. Reducing signaling through $\beta$-arrestin may allow for the use of KOR agonists by reducing the incidence of therapeutically limiting side-effects.

The G protein-biased KOR agonist triazole 1.1 did not suppress ICSS thresholds, reduce NAc dopamine release, or inhibit novelty-induced locomotion at doses producing analgesia equivalent to U50,488 (Brust et al., 2016a). These results support the hypothesis that a G protein-biased KOR agonist would not produce the sedative and dysphoric effects that have limited traditional, unbiased agonist. Another G protein-biased KOR agonist, RB-64, however, produced CPA in both wild-type and $\beta$-arrestin2 $\mathrm{KO}$ mice without inhibiting novelty induced locomotion in either genotype (White et al., 2014). These conflicting results demonstrate the nascency of this line of research. First, more work is needed to determine if traditional KOR-related behavioral outcomes segregate to specific signaling pathways as cleanly as hypothesized. Second, two G protein-biased ligands (as assessed in vitro) may produce disparate results in vivo. While the current body of work focuses on $\mathrm{G}$ protein 
and $\beta$-arrestin pathways, KOR ligands may possess biases in other signaling pathways such as extracellular signal-regulated kinase (ERK) and c-Jun N-terminal kinase (JNK) (Jamshidi et al., 2015) that could explain differences in their behavioral effects in vivo. In addition, differential expression of intracellular effector proteins within different brain regions has been shown to affect the regiospecific signaling efficacy of a biased agonist of the D2 dopamine receptor (Urs et al., 2016b), a process likely at work with KOR ligands.

Taken together, these studies reveal the complexities, and potential promise, of developing such signalingselective ligands. Specific G protein-biased KOR agonists, such as triazole 1.1, may produce analgesia without producing sedative or dysphoric side effects, while others such as RB-64, may lack sedation but not dysphoria. A great deal more research into this field of behavioral pharmacology is required to disentangle the complexities of such biased ligands and their potential utility as replacements for traditional MOR-targeting analgesics.

\section{5 - References}


Abraham AD, Schattauer SS, Reichard KL, Cohen JH, Fontaine HM, Song AJ, Johnson SD, Land BB and Chavkin C (2018) Estrogen Regulation of GRK2 Inactivates Kappa Opioid Receptor Signaling Mediating Analgesia, But Not Aversion. J Neurosci 38:8031-8043.

Al-Hasani R and Bruchas MR (2011) Molecular mechanisms of opioid receptor-dependent signaling and behavior. Anesthesiology 115:1363-1381.

Altarifi AA, David B, Muchhala KH, Blough BE, Akbarali H and Negus SS (2017) Effects of acute and repeated treatment with the biased mu opioid receptor agonist TRV130 (oliceridine) on measures of antinociception, gastrointestinal function, and abuse liability in rodents. Journal of psychopharmacology (Oxford, England) 31:730-739.

Arendt-Nielsen L, Olesen AE, Staahl C, Menzaghi F, Kell S, Wong GY and Drewes AM (2009) Analgesic efficacy of peripheral kappa-opioid receptor agonist CR665 compared to oxycodone in a multi-modal, multi-tissue experimental human pain model: selective effect on visceral pain. Anesthesiology 111:616624.

Barnes NM and Sharp T (1999) A review of central 5-HT receptors and their function. Neuropharmacology 38:1083-1152.

Barry DT, Marshall BDL, Becker WC, Gordon AJ, Crystal S, Kerns RD, Gaither JR, Gordon KS, Justice AC, Fiellin DA and Edelman EJ (2018) Duration of opioid prescriptions predicts incident nonmedical use of prescription opioids among U.S. veterans receiving medical care. Drug and Alcohol Dependence 191:348-354.

Bart G, Heilig M, LaForge KS, Pollak L, Leal SM, Ott J and Kreek MJ (2004) Substantial attributable risk related to a functional mu-opioid receptor gene polymorphism in association with heroin addiction in central Sweden. Mol Psychiatry 9:547-549.

Basbaum AI and Fields HL (1978) Endogenous pain control mechanisms: review and hypothesis. Ann Neurol 4:451-462. 
Basbaum AI and Fields HL (1984a) Endogenous pain control systems: brainstem spinal pathways and endorphin circuitry. Annu Rev Neurosci 7:309-338.

Basbaum AI and Fields HL (1984b) Endogenous Pain Control Systems: Brainstem Spinal Pathways and Endorphin Circuitry. 7:309-338.

Behbehani MM (1995) Functional characteristics of the midbrain periaqueductal gray. Prog Neurobiol 46:575605.

Besse D, Lombard MC, Zajac JM, Roques BP and Besson JM (1990) Pre- and postsynaptic distribution of mu, delta and kappa opioid receptors in the superficial layers of the cervical dorsal horn of the rat spinal cord. Brain Res 521:15-22.

Bie B and Pan ZZ (2003) Presynaptic mechanism for anti-analgesic and anti-hyperalgesic actions of kappaopioid receptors. J Neurosci 23:7262-7268.

Black D and Trevethick M (1998) The kappa opioid receptor is associated with the perception of visceral pain. Gut 43:312-313.

Blum K, Chen ALC, Thanos PK, Febo M, Demetrovics Z, Dushaj K, Kovoor A, Baron D, Smith DE, Roy AK, Fried L, Chen TJH, Chapman E, Modestino EJ, Steinberg B and Badgaiyan RD (2018) Genetic addiction risk score (GARS) ${ }^{\mathrm{TM}}$, a predictor of vulnerability to opioid dependence, in Front Biosci (Elite Ed) pp 175-196.

Bohn LM (1999) Enhanced Morphine Analgesia in Mice Lacking -Arrestin 2. Science 286:2495-2498.

Bohn LM, Gainetdinov RR, Lin F-T, Lefkowitz RJ and Caron MG (2000) $\mu$-Opioid receptor desensitization by $\beta$-arrestin-2 determines morphine tolerance but not dependence. Nature 408:720-723.

Bond C, LaForge KS, Tian M, Melia D, Zhang S, Borg L, Gong J, Schluger J, Strong JA, Leal SM, Tischfield JA, Kreek MJ and Yu L (1998) Single-nucleotide polymorphism in the human mu opioid receptor gene alters beta-endorphin binding and activity: possible implications for opiate addiction. Proc Natl Acad Sci U $A$ 95:9608-9613. 
Boudreau D, Von Korff M, Rutter CM, Saunders K, Ray GT, Sullivan MD, Campbell CI, Merrill JO, Silverberg MJ, Banta-Green C and Weisner C (2009) Trends in long-term opioid therapy for chronic non-cancer pain. Pharmacoepidemiology and drug safety 18:1166-1175.

Bozarth MA and Wise RA (1981) Intracranial self-administration of morphine into the ventral tegmental area in rats. Life Sci 28:551-555.

Brat GA, Agniel D, Beam A, Yorkgitis B, Bicket M, Homer M, Fox KP, Knecht DB, McMahill-Walraven CN, Palmer N and Kohane I (2018) Postsurgical prescriptions for opioid naive patients and association with overdose and misuse: retrospective cohort study. BMJ (Clinical research ed) 360:j5790-j5790.

Briggs SL, Rech RH and Sawyer DC (1998) Kappa Antinociceptive Activity of Spiradoline in the Cold-Water Tail-Flick Assay in Rats. Pharmacology Biochemistry and Behavior 60:467-472.

Bromberg-Martin ES, Matsumoto M and Hikosaka O (2010) Dopamine in motivational control: rewarding, aversive, and alerting. Neuron 68:815-834.

Bruchas MR, Land BB, Aita M, Xu M, Barot SK, Li S and Chavkin C (2007) Stress-Induced p38 MitogenActivated Protein Kinase Activation Mediates -Opioid-Dependent Dysphoria. 27:11614-11623.

Bruchas MR, Land BB and Chavkin C (2010) The dynorphin/kappa opioid system as a modulator of stressinduced and pro-addictive behaviors. Brain Res 1314:44-55.

Bruchas MR, Land BB, Lemos JC and Chavkin C (2009) CRF1-R activation of the dynorphin/kappa opioid system in the mouse basolateral amygdala mediates anxiety-like behavior. PLoS One 4:e8528.

Bruchas MR, Macey TA, Lowe JD and Chavkin C (2006) Kappa opioid receptor activation of p38 MAPK is GRK3- and arrestin-dependent in neurons and astrocytes. The Journal of biological chemistry 281:18081-18089.

Bruchas MR, Schindler AG, Shankar H, Messinger DI, Miyatake M, Land BB, Lemos JC, Hagan CE, Neumaier JF, Quintana A, Palmiter RD and Chavkin C (2011) Selective p38alpha MAPK deletion in serotonergic neurons produces stress resilience in models of depression and addiction. Neuron 71:498-511. 
Brust TF, Morgenweck J, Kim SA, Rose JH, Locke JL, Schmid CL, Zhou L, Stahl EL, Cameron MD, Scarry SM, Aube J, Jones SR, Martin TJ and Bohn LM (2016a) Biased agonists of the kappa opioid receptor suppress pain and itch without causing sedation or dysphoria. Sci Signal 9:ra117.

Brust TF, Morgenweck J, Kim SA, Rose JH, Locke JL, Schmid CL, Zhou L, Stahl EL, Cameron MD, Scarry SM, Aube J, Jones SR, Martin TJ and Bohn LM (2016b) Biased agonists of the kappa opioid receptor suppress pain and itch without causing sedation or dysphoria. 9:ra117-ra117.

Cami-Kobeci G, Neal AP, Bradbury FA, Purington LC, Aceto MD, Harris LS, Lewis JW, Traynor JR and Husbands SM (2009) Mixed kappa/mu opioid receptor agonists: the 6 beta-naltrexamines. $J$ Med Chem 52:1546-1552.

Cao J, LaRocque E and Li D (2013) Associations of the 5-hydroxytryptamine (serotonin) receptor 1B gene (HTR1B) with alcohol, cocaine, and heroin abuse. Am J Med Genet B Neuropsychiatr Genet 162B:169176.

Cara (2018) A Study to Evaluate the Safety and Efficacy of CR845 in Hemodialysis Patients With Moderate-toSevere Pruritus, in.

Carlezon WA, Jr., Beguin C, DiNieri JA, Baumann MH, Richards MR, Todtenkopf MS, Rothman RB, Ma Z, Lee DY and Cohen BM (2006) Depressive-like effects of the kappa-opioid receptor agonist salvinorin A on behavior and neurochemistry in rats. J Pharmacol Exp Ther 316:440-447.

Carlezon WA, Jr., Duman RS and Nestler EJ (2005) The many faces of CREB. Trends Neurosci 28:436-445.

CDC CfDCaP (2017) U.S. Opioid Prescribing Rate Maps, in.

CDC CfDCaP (2018) Guideline for Prescribing Opioids for Chronic Pain.

Cepeda MS and Carr DB (2003) Women experience more pain and require more morphine than men to achieve a similar degree of analgesia. Anesth Analg 97:1464-1468.

Cervero F and Laird JM (1999) Visceral pain. Lancet 353:2145-2148.

Chavkin C and Koob GF (2016) Dynorphin, Dysphoria, and Dependence: the Stress of Addiction. Neuropsychopharmacology 41:373-374. 
Chefer VI, Backman CM, Gigante ED and Shippenberg TS (2013) Kappa opioid receptors on dopaminergic neurons are necessary for kappa-mediated place aversion. Neuropsychopharmacology 38:2623-2631. Chen KY, Chen L and Mao J (2014) Buprenorphine-Naloxone Therapy in Pain Management. 120:1262-1274. Chou W-YMD, Wang C-HMD, Liu P-HMD, Liu C-CMD, Tseng C-CMD and Jawan BMD (2006) Human Opioid Receptor A118G Polymorphism Affects Intravenous Patient-controlled Analgesia Morphine Consumption after Total Abdominal Hysterectomy. Anesthesiology: The Journal of the American Society of Anesthesiologists 105:334-337.

Christo PJ and Mazloomdoost D (2008) Cancer pain and analgesia. Ann N Y Acad Sci 1138:278-298.

Clark JA and Pasternak GW (1988) U50,488: a kappa-selective agent with poor affinity for mu1 opiate binding sites. Neuropharmacology 27:331-332.

Clarke TK, Ambrose-Lanci L, Ferraro TN, Berrettini WH, Kampman KM, Dackis CA, Pettinati HM, O'Brien CP, Oslin DW and Lohoff FW (2012) Genetic association analyses of PDYN polymorphisms with heroin and cocaine addiction. Genes Brain Behav 11:415-423.

Clarke TK, Crist RC, Kampman KM, Dackis CA, Pettinati HM, O'Brien CP, Oslin DW, Ferraro TN, Lohoff FW and Berrettini WH (2013) Low frequency genetic variants in the mu-opioid receptor (OPRM1) affect risk for addiction to heroin and cocaine. Neurosci Lett 542:71-75.

Connor M and Christie MJ (1999) OPIOID RECEPTOR SIGNALLING MECHANISMS. Clinical and Experimental Pharmacology and Physiology 26:493-499.

Courtwright DT (1978) Opiate Addiction as a Consequence of the Civil War. Civil War History 24:101-111.

Crowley NA and Kash TL (2015) Kappa opioid receptor signaling in the brain: Circuitry and implications for treatment. Prog Neuropsychopharmacol Biol Psychiatry 62:51-60.

David V and Cazala P (1994) Differentiation of intracranial morphine self-administration behavior among five brain regions in mice. Pharmacol Biochem Behav 48:625-633.

Dyer O (2014) Kentucky seeks \$1bn from Purdue Pharma for misrepresenting addictive potential of oxycodone. BMJ : British Medical Journal 349:g6605. 
Ehrich JM, Messinger DI, Knakal CR, Kuhar JR, Schattauer SS, Bruchas MR, Zweifel LS, Kieffer BL, Phillips PE and Chavkin C (2015a) Kappa Opioid Receptor-Induced Aversion Requires p38 MAPK Activation in VTA Dopamine Neurons. J Neurosci 35:12917-12931.

Ehrich JM, Messinger DI, Knakal CR, Kuhar JR, Schattauer SS, Bruchas MR, Zweifel LS, Kieffer BL, Phillips PEM and Chavkin C (2015b) Kappa Opioid Receptor-Induced Aversion Requires p38 MAPK Activation in VTA Dopamine Neurons. The Journal of neuroscience : the official journal of the Society for Neuroscience 35:12917-12931.

Ewald AWM, Bosch PJ, Culverhouse A, Crowley RS, Neuenswander B, Prisinzano TE and Kivell BM (2017) The C-2 derivatives of salvinorin A, ethoxymethyl ether Sal B and $\beta$-tetrahydropyran Sal B, have anticocaine properties with minimal side effects. Psychopharmacology 234:2499-2514.

FDA FaDACfDER (2018) FDA Advisory Committee Briefing Document: Oliceridine, in, FDA.

Field MJ, Carnell AJ, Gonzalez MI, McCleary S, Oles RJ, Smith R, Hughes J and Singh L (1999) Enadoline, a selective $\kappa$-opioid receptor agonist shows potent antihyperalgesic and antiallodynic actions in a rat model of surgical pain. Pain 80:383-389.

Fields HL and Basbaum AI (1978) Brainstem control of spinal pain-transmission neurons. Annu Rev Physiol 40:217-248.

Fields HL and Margolis EB (2015) Understanding opioid reward. Trends Neurosci 38:217-225.

Fillingim RB and Gear RW (2004) Sex differences in opioid analgesia: clinical and experimental findings. Eur J Pain 8:413-425.

Fillingim RB, Ness TJ, Glover TL, Campbell CM, Hastie BA, Price DD and Staud R (2005) Morphine responses and experimental pain: sex differences in side effects and cardiovascular responses but not analgesia. J Pain 6:116-124.

Froehlich JC (1997) Opioid peptides. Alcohol Health Res World 21:132-136.

Gao F, Zhu YS, Wei SG, Li SB and Lai JH (2011) Polymorphism G861C of 5-HT receptor subtype 1B is associated with heroin dependence in Han Chinese. Biochem Biophys Res Commun 412:450-453. 
Gao X, Wang Y, Lang M, Yuan L, Reece AS and Wang W (2017) Contribution of Genetic Polymorphisms and Haplotypes in DRD2, BDNF, and Opioid Receptors to Heroin Dependence and Endophenotypes Among the Han Chinese. OMICS 21:404-412.

Gear RW, Miaskowski C, Gordon NC, Paul SM, Heller PH and Levine JD (1996) Kappa-opioids produce significantly greater analgesia in women than in men. Nat Med 2:1248-1250.

Ghelardini C, Di Cesare Mannelli L and Bianchi E (2015a) The pharmacological basis of opioids. Clinical cases in mineral and bone metabolism : the official journal of the Italian Society of Osteoporosis, Mineral Metabolism, and Skeletal Diseases 12:219-221.

Ghelardini C, Di Cesare Mannelli L and Bianchi E (2015b) The pharmacological basis of opioids. Clin Cases Miner Bone Metab 12:219-221.

Gilpin NW, Roberto M, Koob GF and Schweitzer P (2014) Kappa opioid receptor activation decreases inhibitory transmission and antagonizes alcohol effects in rat central amygdala. Neuropharmacology 77:294-302.

Goldfarb AH and Jamurtas AZ (1997) Beta-endorphin response to exercise. An update. Sports Med 24:8-16. Gomes T, Mamdani MM, Dhalla IA, Paterson JM and Juurlink DN (2011) Opioid Dose and Drug-Related Mortality in Patients With Nonmalignant Pain. Archives of Internal Medicine 171.

Gourlay GK, Kowalski SR, Plummer JL, Cousins MJ and Armstrong PJ (1988) Fentanyl blood concentrationanalgesic response relationship in the treatment of postoperative pain. Anesth Analg 67:329-337.

Greedy BM, Bradbury F, Thomas MP, Grivas K, Cami-Kobeci G, Archambeau A, Bosse K, Clark MJ, Aceto M, Lewis JW, Traynor JR and Husbands SM (2013) Orvinols with mixed kappa/mu opioid receptor agonist activity. $J$ Med Chem 56:3207-3216.

Greenwald MK and Stitzer ML (1998) Butorphanol agonist effects and acute physical dependence in opioid abusers: comparison with morphine. Drug Alcohol Depend 53:17-30.

Gutstein HB, Mansour A, Watson SJ, Akil H and Fields HL (1998) Mu and kappa opioid receptors in periaqueductal gray and rostral ventromedial medulla. Neuroreport 9:1777-1781. 
Haerian BS and Haerian MS (2013) OPRM1 rs1799971 polymorphism and opioid dependence: evidence from a meta-analysis. Pharmacogenomics 14:813-824.

Hauser AS, Attwood MM, Rask-Andersen M, Schiöth HB and Gloriam DE (2017) Trends in GPCR drug discovery: new agents, targets and indications. Nature Reviews Drug Discovery 16:829-842.

He L and Lee NM (1997) DynorphinA-(2-17) restores spinal/supraspinal morphine synergy in morphinetolerant mice. J Pharmacol Exp Ther 280:1210-1214.

Hnasko TS, Sotak BN and Palmiter RD (2005) Morphine reward in dopamine-deficient mice. Nature 438:854857.

Hoskin PJ and Hanks GW (1991) Opioid agonist-antagonist drugs in acute and chronic pain states. Drugs 41:326-344.

Huge V, Rammes G, Beyer A, Zieglgansberger W and Azad SC (2009) Activation of kappa opioid receptors decreases synaptic transmission and inhibits long-term potentiation in the basolateral amygdala of the mouse. Eur J Pain 13:124-129.

Jamshidi RJ, Jacobs BA, Sullivan LC, Chavera TA, Saylor RM, Prisinzano TE, Clarke WP and Berg KA (2015) Functional selectivity of kappa opioid receptor agonists in peripheral sensory neurons. The Journal of pharmacology and experimental therapeutics 355:174-182.

Jasinski DR and Mansky PA (1972) Evaluation of nalbuphine for abuse potential. Clin Pharmacol Ther 13:7890.

Johnson SW and North RA (1992) Opioids excite dopamine neurons by hyperpolarization of local interneurons. J Neurosci 12:483-488.

Jones CM (2013) Heroin use and heroin use risk behaviors among nonmedical users of prescription opioid pain relievers - United States, 2002-2004 and 2008-2010. Drug and Alcohol Dependence 132:95-100.

Jones CM, Muhuri PK and Lurie PG (2017) Trends in the Nonmedical Use of OxyContin, United States, 2006 to 2013. The Clinical Journal of Pain 33:452-461. 
Kamp EH, Jones RC, 3rd, Tillman SR and Gebhart GF (2003) Quantitative assessment and characterization of visceral nociception and hyperalgesia in mice. Am J Physiol Gastrointest Liver Physiol 284:G434-444.

Kang-Park M, Kieffer BL, Roberts AJ, Siggins GR and Moore SD (2013) kappa-Opioid receptors in the central amygdala regulate ethanol actions at presynaptic GABAergic sites. $J$ Pharmacol Exp Ther 346:130-137.

Kendler KS, Jacobson KC, Prescott CA and Neale MC (2003) Specificity of Genetic and Environmental Risk Factors for Use and Abuse/Dependence of Cannabis, Cocaine, Hallucinogens, Sedatives, Stimulants, and Opiates in Male Twins. American Journal of Psychiatry 160:687-695.

Khotib J, Narita M, Suzuki M, Yajima Y and Suzuki T (2004) Functional interaction among opioid receptor types: up-regulation of mu- and delta-opioid receptor functions after repeated stimulation of kappaopioid receptors. Neuropharmacology 46:531-540.

Kivell B and Prisinzano TE (2010) Kappa opioids and the modulation of pain. Psychopharmacology (Berl) 210:109-119.

Kline RHt and Wiley RG (2008) Spinal mu-opioid receptor-expressing dorsal horn neurons: role in nociception and morphine antinociception. $J$ Neurosci 28:904-913.

Knoll AT and Carlezon WA, Jr. (2010) Dynorphin, stress, and depression. Brain Res 1314:56-73.

Knoll AT, Muschamp JW, Sillivan SE, Ferguson D, Dietz DM, Meloni EG, Carroll FI, Nestler EJ, Konradi C and Carlezon WA, Jr. (2011) Kappa opioid receptor signaling in the basolateral amygdala regulates conditioned fear and anxiety in rats. Biol Psychiatry 70:425-433.

Koob GF (2008) Hedonic Homeostatic Dysregulation as a Driver of Drug-Seeking Behavior. Drug Discov Today Dis Models 5:207-215.

Koob GF (2013) Addiction is a Reward Deficit and Stress Surfeit Disorder. Front Psychiatry 4:72.

Koob GF and Le Moal M (1997) Drug abuse: hedonic homeostatic dysregulation. Science 278:52-58.

Koob GF and Le Moal M (2001) Drug addiction, dysregulation of reward, and allostasis. Neuropsychopharmacology 24:97-129.

Koob GF and Schulkin J (2018) Addiction and stress: An allostatic view. Neurosci Biobehav Rev. 
Koob GF and Volkow ND (2016) Neurobiology of addiction: a neurocircuitry analysis. Lancet Psychiatry 3:760-773.

Kumar D, Chakraborty J and Das S (2012) Epistatic effects between variants of kappa-opioid receptor gene and A118G of mu-opioid receptor gene increase susceptibility to addiction in Indian population. Prog Neuropsychopharmacol Biol Psychiatry 36:225-230.

Lalanne L, Ayranci G, Kieffer BL and Lutz PE (2014) The kappa opioid receptor: from addiction to depression, and back. Front Psychiatry 5:170.

Land BB, Bruchas MR, Lemos JC, Xu M, Melief EJ and Chavkin C (2008) The dysphoric component of stress is encoded by activation of the dynorphin kappa-opioid system. $J$ Neurosci 28:407-414.

Land BB, Bruchas MR, Schattauer S, Giardino WJ, Aita M, Messinger D, Hnasko TS, Palmiter RD and Chavkin C (2009) Activation of the kappa opioid receptor in the dorsal raphe nucleus mediates the aversive effects of stress and reinstates drug seeking. Proc Natl Acad Sci U S A 106:19168-19173.

Le Merrer J, Becker JA, Befort K and Kieffer BL (2009) Reward processing by the opioid system in the brain. Physiol Rev 89:1379-1412.

Lee CW and Ho IK (2013) Sex differences in opioid analgesia and addiction: interactions among opioid receptors and estrogen receptors. Mol Pain 9:45.

Leone P, Pocock D and Wise RA (1991) Morphine-dopamine interaction: ventral tegmental morphine increases nucleus accumbens dopamine release. Pharmacol Biochem Behav 39:469-472.

Levran O, Londono D, O'Hara K, Nielsen DA, Peles E, Rotrosen J, Casadonte P, Linzy S, Randesi M, Ott J, Adelson M and Kreek MJ (2008) Genetic susceptibility to heroin addiction: a candidate gene association study. Genes Brain Behav 7:720-729.

Levran O, Londono D, O'Hara K, Randesi M, Rotrosen J, Casadonte P, Linzy S, Ott J, Adelson M and Kreek MJ (2009) Heroin addiction in African Americans: a hypothesis-driven association study. Genes Brain Behav 8:531-540. 
Llewelyn MB, Azami J, Gibbs M and Roberts MH (1983) A comparison of the sites at which pentazocine and morphine act to produce analgesia. Pain 16:313-331.

Luo M, Zhou J and Liu Z (2015) Reward processing by the dorsal raphe nucleus: 5-HT and beyond. Learn Mem 22:452-460.

Mague SD, Pliakas AM, Todtenkopf MS, Tomasiewicz HC, Zhang Y, Stevens WC, Jr., Jones RM, Portoghese PS and Carlezon WA, Jr. (2003) Antidepressant-like effects of kappa-opioid receptor antagonists in the forced swim test in rats. $J$ Pharmacol Exp Ther 305:323-330.

Mantsch JR, Baker DA, Funk D, Le AD and Shaham Y (2016) Stress-Induced Reinstatement of Drug Seeking: 20 Years of Progress. Neuropsychopharmacology 41:335-356.

Manzanedo C, Aguilar MA, Rodriguez-Arias M and Minarro J (2001) Effects of dopamine antagonists with different receptor blockade profiles on morphine-induced place preference in male mice. Behav Brain Res 121:189-197.

Marchant NJ, Densmore VS and Osborne PB (2007) Coexpression of prodynorphin and corticotrophinreleasing hormone in the rat central amygdala: evidence of two distinct endogenous opioid systems in the lateral division. J Comp Neurol 504:702-715.

Martell BA, O'Connor PG, Kerns RD, Becker WC, Morales KH, Kosten TR and Fiellin DA (2007) Systematic Review: Opioid Treatment for Chronic Back Pain: Prevalence, Efficacy, and Association with AddictionOpioid Treatment for Chronic Back Pain. Annals of Internal Medicine 146:116-127.

Maund E, McDaid C, Rice S, Wright K, Jenkins B and Woolacott N (2011) Paracetamol and selective and nonselective non-steroidal anti-inflammatory drugs for the reduction in morphine-related side-effects after major surgery: a systematic review. 106:292-297.

McCudden CR, Hains MD, Kimple RJ, Siderovski DP and Willard FS (2005) G-protein signaling: back to the future. Cellular and molecular life sciences : CMLS 62:551-577.

McEwen BS (1998) Stress, adaptation, and disease. Allostasis and allostatic load. Ann N Y Acad Sci 840:33-44. 
McLaughlin JP, Marton-Popovici M and Chavkin C (2003) Kappa opioid receptor antagonism and prodynorphin gene disruption block stress-induced behavioral responses. J Neurosci 23:5674-5683. Miaskowski C and Levine JD (1999) Does opioid analgesia show a gender preference for females? Pain Forum 8:34-44.

Miller PL and Ernst AA (2004) Sex differences in analgesia: a randomized trial of mu versus kappa opioid agonists. South Med J 97:35-41.

Moriwaki A, Wang JB, Svingos A, van Bockstaele E, Cheng P, Pickel V and Uhl GR (1996) mu Opiate receptor immunoreactivity in rat central nervous system. Neurochem Res 21:1315-1331.

Mysels D and Sullivan MA (2009) The kappa-opiate receptor impacts the pathophysiology and behavior of substance use. Am J Addict 18:272-276.

Nabeshima T, Katoh A, Wada M and Kameyama T (1992) Stress-induced changes in brain Met-enkephalin, Leu-enkephalin and dynorphin concentrations. Life Sci 51:211-217.

Narita M, Matsushima Y, Niikura K, Narita M, Takagi S, Nakahara K, Kurahashi K, Abe M, Saeki M, Asato M, Imai S, Ikeda K, Kuzumaki N and Suzuki T (2010) Implication of dopaminergic projection from the ventral tegmental area to the anterior cingulate cortex in $\mu$-opioid-induced place preference. Addiction Biology 15:434-447.

Negus SS and Freeman KB (2018) Abuse Potential of Biased Mu Opioid Receptor Agonists. Trends in Pharmacological Sciences 39:916-919.

Negus SS, Schrode K and Stevenson GW (2008) Micro/kappa opioid interactions in rhesus monkeys: implications for analgesia and abuse liability. Experimental and clinical psychopharmacology 16:386399.

Nelson EC, Lynskey MT, Heath AC, Wray N, Agrawal A, Shand FL, Henders AK, Wallace L, Todorov AA, Schrage AJ, Madden PA, Degenhardt L, Martin NG and Montgomery GW (2014) Association of OPRD1 polymorphisms with heroin dependence in a large case-control series. Addict Biol 19:111-121. 
Nestler EJ and Carlezon WA, Jr. (2006) The mesolimbic dopamine reward circuit in depression. Biol Psychiatry 59:1151-1159.

Niesters M, Dahan A, Kest B, Zacny J, Stijnen T, Aarts L and Sarton E (2010) Do sex differences exist in opioid analgesia? A systematic review and meta-analysis of human experimental and clinical studies. Pain 151:61-68.

Olmstead MC and Franklin KB (1997) The development of a conditioned place preference to morphine: effects of microinjections into various CNS sites. Behav Neurosci 111:1324-1334.

Pan ZZ, Tershner SA and Fields HL (1997) Cellular mechanism for anti-analgesic action of agonists of the kappa-opioid receptor. Nature 389:382-385.

Pasternak GW (1981) Central mechanisms of opioid analgesia. Acupunct Electrother Res 6:135-149.

Pasternak GW (1993) Pharmacological Mechanisms of Opioid Analgesics. 16:1-18.

Pasternak GW (2005a) Molecular Biology of Opioid Analgesia. Journal of Pain and Symptom Management 29:2-9.

Pasternak GW (2005b) Molecular biology of opioid analgesia. J Pain Symptom Manage 29:S2-9.

Pfeiffer A, Brantl V, Herz A and Emrich HM (1986) Psychotomimesis mediated by kappa opiate receptors. Science 233:774-776.

Phillips DM (2000) JCAHO Pain Management Standards Are Unveiled. JAMA 284:428-429.

Pizziketti RJ, Pressman NS, Geller EB, Cowan A and Adler MW (1985) Rat cold water tail-flick: A novel analgesic test that distinguishes opioid agonists from mixed agonist-antagonists. European Journal of Pharmacology 119:23-29.

Porreca F and Navratilova E (2017) Reward, motivation, and emotion of pain and its relief. Pain 158 Suppl 1:S43-S49.

Portenoy RK and Foley KM (1986) Chronic use of opioid analgesics in non-malignant pain: Report of 38 cases. Pain 25:171-186.

Porter J and Jick H (1980) Addiction Rare in Patients Treated with Narcotics. 302:123-123. 
Preston KL and Bigelow GE (1993) Differential naltrexone antagonism of hydromorphone and pentazocine effects in human volunteers. J Pharmacol Exp Ther 264:813-823.

Preston KL, Bigelow GE, Bickel WK and Liebson IA (1989a) Drug discrimination in human postaddicts: agonist-antagonist opioids. J Pharmacol Exp Ther 250:184-196.

Preston KL, Bigelow GE and Liebson IA (1987) Comparative evaluation of morphine, pentazocine and ciramadol in postaddicts. J Pharmacol Exp Ther 240:900-910.

Preston KL, Bigelow GE and Liebson IA (1988) Butorphanol-precipitated withdrawal in opioid-dependent human volunteers. J Pharmacol Exp Ther 246:441-448.

Preston KL, Bigelow GE and Liebson IA (1989b) Antagonist effects of nalbuphine in opioid-dependent human volunteers. J Pharmacol Exp Ther 248:929-937.

Raehal KM (2005) Morphine Side Effects in -Arrestin 2 Knockout Mice. 314:1195-1201.

Rasmussen K, White DA and Acri JB (2019) NIDA's medication development priorities in response to the Opioid Crisis: ten most wanted. Neuropsychopharmacology 44:657-659.

Redila VA and Chavkin C (2008) Stress-induced reinstatement of cocaine seeking is mediated by the kappa opioid system. Psychopharmacology (Berl) 200:59-70.

Remillard D, Kaye AD and McAnally H (2019) Oxycodone's Unparalleled Addictive Potential: Is it Time for a Moratorium? Current Pain and Headache Reports 23.

Remy C (2005) Effects of acetaminophen on morphine side-effects and consumption after major surgery: metaanalysis of randomized controlled trials. 94:505-513.

Research FDACfDE (2018) Oliceridine Briefing Document, in, FDA.

Rosenblum A, Marsch LA, Joseph H and Portenoy RK (2008) Opioids and the treatment of chronic pain: controversies, current status, and future directions. Experimental and clinical psychopharmacology 16:405-416. 
Ruan X, Hall SM and Kaye AD (2016) Nalfurafine hydrochloride, a selective kappa opioid receptor agonist, has no reinforcing effect on intravenous self-administration in rhesus monkeys. J Pharmacol Sci 132:113-114.

Rubinstein M, Mogil JS, Japon M, Chan EC, Allen RG and Low MJ (1996) Absence of opioid stress-induced analgesia in mice lacking beta-endorphin by site-directed mutagenesis. Proc Natl Acad Sci U S A 93:3995-4000.

Saadé NE, Atweh SF, Bahuth NB and Jabbur SJ (1997) Augmentation of nociceptive reflexes and chronic deafferentation pain by chemical lesions of either dopaminergic terminals or midbrain dopaminergic neurons. Brain Research 751:1-12.

Saiz PA, Garcia-Portilla MP, Arango C, Morales B, Martinez-Barrondo S, Alvarez C, San Narciso G, Carreno E, Alvarez V, Coto E and Bobes J (2008) Association between heroin dependence and 5-HT2A receptor gene polymorphisms. Eur Addict Res 14:47-52.

Salamone JD and Correa M (2012) The mysterious motivational functions of mesolimbic dopamine. Neuron 76:470-485.

Salsitz EA (2016) Chronic Pain, Chronic Opioid Addiction: a Complex Nexus. Journal of medical toxicology : official journal of the American College of Medical Toxicology 12:54-57.

SAMHSA SAaMHSA (2018) SAMHSA/HHS: An Update on the Opioid Crisis, in, SAMHSA.

Schmid CL, Kennedy NM, Ross NC, Lovell KM, Yue Z, Morgenweck J, Cameron MD, Bannister TD and Bohn LM (2017) Bias Factor and Therapeutic Window Correlate to Predict Safer Opioid Analgesics. Cell 171:1165-1175.e1113.

Serra V, Fattore L, Scherma M, Collu R, Spano MS, Fratta W and Fadda P (2015) Behavioural and neurochemical assessment of salvinorin A abuse potential in the rat. Psychopharmacology (Berl) 232:91-100. 
Shah A, Hayes CJ and Martin BC (2017) Factors Influencing Long-Term Opioid Use Among Opioid Naive Patients: An Examination of Initial Prescription Characteristics and Pain Etiologies. The Journal of Pain 18: $1374-1383$.

Shippenberg TS, Chefer VI and Thompson AC (2009) Delta-opioid receptor antagonists prevent sensitization to the conditioned rewarding effects of morphine. Biol Psychiatry 65:169-174.

Sibille KT, Kindler LL, Glover TL, Gonzalez RD, Staud R, Riley JL, 3rd and Fillingim RB (2011) Individual differences in morphine and butorphanol analgesia: a laboratory pain study. Pain Med 12:1076-1085.

Siebert DJ (1994) Salvia divinorum and salvinorin A: new pharmacologic findings. J Ethnopharmacol 43:5356.

Soergel DG, Subach RA, Burnham N, Lark MW, James IE, Sadler BM, Skobieranda F, Violin JD and Webster LR (2014) Biased agonism of the $\mu$-opioid receptor by TRV130 increases analgesia and reduces ontarget adverse effects versus morphine: A randomized, double-blind, placebo-controlled, crossover study in healthy volunteers. Pain 155:1829-1835.

Sophie M and Ford B (2012) Management of Pain in Parkinson's Disease. CNS Drugs 26:937-948.

Spahn V, Del Vecchio G, Labuz D, Rodriguez-Gaztelumendi A, Massaly N, Temp J, Durmaz V, Sabri P, Reidelbach M, Machelska H, Weber M and Stein C (2017) A nontoxic pain killer designed by modeling of pathological receptor conformations. Science 355:966-969.

Stein C (2016a) Opioid Receptors. Annu Rev Med 67:433-451.

Stein C (2016b) Opioid Receptors. Annual Review of Medicine 67:433-451.

Steiner H and Gerfen CR (1998) Role of dynorphin and enkephalin in the regulation of striatal output pathways and behavior. Exp Brain Res 123:60-76.

Strain EC, Preston KL, Liebson IA and Bigelow GE (1993) Precipitated withdrawal by pentazocine in methadone-maintained volunteers. J Pharmacol Exp Ther 267:624-634.

Su X, Joshi SK, Kardos S and Gebhart GF (2002) Sodium channel blocking actions of the kappa-opioid receptor agonist U50,488 contribute to its visceral antinociceptive effects. J Neurophysiol 87:1271-1279. 
Suzuki T, Tsuji M, Mori T, Misawa M, Endoh T and Nagase H (1996) Effect of the highly selective and nonpeptide delta opioid receptor agonist TAN-67 on the morphine-induced place preference in mice. $J$ Pharmacol Exp Ther 279:177-185.

Svingos AL, Chavkin C, Colago EE and Pickel VM (2001) Major coexpression of kappa-opioid receptors and the dopamine transporter in nucleus accumbens axonal profiles. Synapse 42:185-192.

Tan EC, Lim EC, Teo YY, Lim Y, Law HY and Sia AT (2009) Ethnicity and OPRM variant independently predict pain perception and patient-controlled analgesia usage for post-operative pain. Mol Pain 5:32.

Tang AH and Collins RJ (1985) Behavioral effects of a novel kappa opioid analgesic, U-50488, in rats and rhesus monkeys. Psychopharmacology (Berl) 85:309-314.

Tao PL, Liang KW, Sung WY, Wu YT and Huang EY (2006) Nalbuphine is effective in decreasing the rewarding effect induced by morphine in rats. Drug Alcohol Depend 84:175-181.

Tao R and Auerbach SB (2005) mu-Opioids disinhibit and kappa-opioids inhibit serotonin efflux in the dorsal raphe nucleus. Brain Res 1049:70-79.

Tershner SA, Mitchell JM and Fields HL (2000) Brainstem pain modulating circuitry is sexually dimorphic with respect to mu and kappa opioid receptor function. Pain 85:153-159.

Todd AJ (2010a) Neuronal circuitry for pain processing in the dorsal horn. Nat Rev Neurosci 11:823-836.

Todd AJ (2010b) Neuronal circuitry for pain processing in the dorsal horn. Nature reviews Neuroscience 11:823-836.

Todtenkopf MS, Marcus JF, Portoghese PS and Carlezon WA, Jr. (2004) Effects of kappa-opioid receptor ligands on intracranial self-stimulation in rats. Psychopharmacology (Berl) 172:463-470.

Tsuang MT, Lyons MJ, Meyer JM, Doyle T, Eisen SA, Goldberg J, True W, Lin N, Toomey R and Eaves L (1998) Co-occurrence of Abuse of Different Drugs in Men. Archives of General Psychiatry 55:967. Urs NM, Gee SM, Pack TF, McCorvy JD, Evron T, Snyder JC, Yang X, Rodriguiz RM, Borrelli E, Wetsel WC, Jin J, Roth BL, O’Donnell P and Caron MG (2016) Distinct cortical and striatal actions of a $\beta$-arrestinbiased dopamine D2 receptor ligand reveal unique antipsychotic-like properties. 113:E8178-E8186. 
Valentino RJ and Volkow ND (2018) Untangling the complexity of opioid receptor function.

Neuropsychopharmacology 43:2514-2520.

Veening JG and Barendregt HP (2015) The effects of beta-endorphin: state change modification. Fluids Barriers CNS 12:3.

Verborgh CM, Camu F and Meert TF (1997) Interaction between sufentanil and U-50488H with respect to antinociception and respiratory depression in rats. Acta Anaesthesiol Scand 41:895-902.

Volkow ND and McLellan AT (2016) Opioid Abuse in Chronic Pain — Misconceptions and Mitigation Strategies. 374:1253-1263.

Vowles KE, McEntee ML, Julnes PS, Frohe T, Ney JP and van der Goes DN (2015) Rates of opioid misuse, abuse, and addiction in chronic pain: a systematic review and data synthesis. 156:569-576.

Walker BM and Koob GF (2008) Pharmacological evidence for a motivational role of kappa-opioid systems in ethanol dependence. Neuropsychopharmacology 33:643-652.

Walsh SL and Babalonis S (2017) The Abuse Potential of Prescription Opioids in Humans-Closing in on the First Century of Research. Curr Top Behav Neurosci 34:33-58.

Walsh SL, Chausmer AE, Strain EC and Bigelow GE (2008) Evaluation of the mu and kappa opioid actions of butorphanol in humans through differential naltrexone blockade. Psychopharmacology (Berl) 196:143155.

Wang XM, Zhou Y, Spangler R, Ho A, Han JS and Kreek MJ (1999) Acute intermittent morphine increases preprodynorphin and kappa opioid receptor mRNA levels in the rat brain. Brain Res Mol Brain Res 66:184-187.

Wei SG, Zhu YS, Lai JH, Xue HX, Chai ZQ and Li SB (2011) Association between heroin dependence and prodynorphin gene polymorphisms. Brain Res Bull 85:238-242.

White KL, Robinson JE, Zhu H, Diberto JF, Polepally PR, Zjawiony JK, Nichols DE, Malanga CJ and Roth BL (2014) The G Protein-Biased -Opioid Receptor Agonist RB-64 Is Analgesic with a Unique Spectrum of Activities In Vivo. Journal of Pharmacology and Experimental Therapeutics 352:98-109. 
WHO WHO (1996) Cancer pain relief : with a guide to opioid availability, 2nd ed., in, World Health Organization, Geneva.

Wilkerson RG, Kim HK, Windsor TA and Mareiniss DP (2016) The Opioid Epidemic in the United States. Emerg Med Clin North Am 34:e1-e23.

Winkler CW, Hermes SM, Chavkin CI, Drake CT, Morrison SF and Aicher SA (2006) Kappa opioid receptor (KOR) and GAD67 immunoreactivity are found in OFF and NEUTRAL cells in the rostral ventromedial medulla. J Neurophysiol 96:3465-3473.

Wise RA (2009) Roles for nigrostriatal--not just mesocorticolimbic--dopamine in reward and addiction. Trends Neurosci 32:517-524.

Wisler JW, Xiao K, Thomsen ARB and Lefkowitz RJ (2014) Recent developments in biased agonism. Current opinion in cell biology 27:18-24.

Xu J, Lu Z, Narayan A, Le Rouzic VP, Xu M, Hunkele A, Brown TG, Hoefer WF, Rossi GC, Rice RC, Martínez-Rivera A, Rajadhyaksha AM, Cartegni L, Bassoni DL, Pasternak GW and Pan Y-X (2017) Alternatively spliced mu opioid receptor C termini impact the diverse actions of morphine. Journal of Clinical Investigation 127:1561-1573.

Xu J, Lu Z, Xu M, Pan L, Deng Y, Xie X, Liu H, Ding S, Hurd YL, Pasternak GW, Klein RJ, Cartegni L, Zhou W and Pan YX (2014) A heroin addiction severity-associated intronic single nucleotide polymorphism modulates alternative pre-mRNA splicing of the mu opioid receptor gene OPRM1 via hnRNPH interactions. J Neurosci 34:11048-11066.

Yaksh TL, Jessell TM, Gamse R, Mudge AW and Leeman SE (1980) Intrathecal morphine inhibits substance P release from mammalian spinal cord in vivo. Nature 286:155-157.

Yuferov V, Fussell D, LaForge KS, Nielsen DA, Gordon D, Ho A, Leal SM, Ott J and Kreek MJ (2004) Redefinition of the human kappa opioid receptor gene (OPRK1) structure and association of haplotypes with opiate addiction. Pharmacogenetics 14:793-804. 
Zacny JP, Lichtor JL, Thapar P, Coalson DW, Flemming D and Thompson WK (1994) Comparing the subjective, psychomotor and physiological effects of intravenous butorphanol and morphine in healthy volunteers. J Pharmacol Exp Ther 270:579-588.

Zangen A, Ikemoto S, Zadina JE and Wise RA (2002) Rewarding and psychomotor stimulant effects of endomorphin-1: anteroposterior differences within the ventral tegmental area and lack of effect in nucleus accumbens. J Neurosci 22:7225-7233.

Zhang Y, Butelman ER, Schlussman SD, Ho A and Kreek MJ (2005a) Effects of the plant-derived hallucinogen salvinorin A on basal dopamine levels in the caudate putamen and in a conditioned place aversion assay in mice: agonist actions at kappa opioid receptors. Psychopharmacology (Berl) 179:551-558.

Zhang Y, Wang D, Johnson AD, Papp AC and Sadée W (2005b) Allelic Expression Imbalance of Human mu Opioid Receptor (OPRM1) Caused by Variant A118G. 280:32618-32624.

Zubieta JK, Bueller JA, Jackson LR, Scott DJ, Xu Y, Koeppe RA, Nichols TE and Stohler CS (2005) Placebo effects mediated by endogenous opioid activity on mu-opioid receptors. J Neurosci 25:7754-7762.

\section{Chapter Two}


Four single nucleotide polymorphisms in genes involved in neuronal signaling are associated with opioid use disorder in West Virginia

\author{
Original Article -in press Journal of Opioid Management
}

Shane W. Kaski, BS; Stephan Brooks, MPH; Sijin Wen, PhD; Marc W. Haut, PhD; David P. Siderovski, PhD; James H. Berry, DO; Laura R. Lander, MSW; Vincent Setola, PhD

Correspondence to be sent to: Vincent Setola, West Virginia University School of Medicine, Morgantown, WV 26506-9229, USA. email: vssetola@hsc.wvu.edu

\title{
2.1 - ABSTRACT
}


Objective: Pilot study to assess utility in opioid use disorder (OUD) of a panel of single nucleotide polymorphisms in genes previously related to substance use disorder (SUD) and/or phenotypes that predispose individuals to OUD/SUD.

Design: Genetic association study.

Setting: West Virginia University’s Chestnut Ridge Center Comprehensive Opioid Abuse Treatment (COAT) clinic for individuals diagnosed with OUD.

Patients: Sixty patients 18 years of age or older with OUD undergoing medication (buprenorphine/naloxone)assisted treatment (MAT); all sixty patients recruited contributed samples for genetic analysis.

Outcome Measure(s): Minor allele frequencies for single nucleotide polymorphisms.

Results: Four of the fourteen single nucleotide polymorphisms examined were present at frequencies that are statistically significantly different than in a demographically-matched general population.

Conclusions: For the purposes of testing WV individuals via genetic means for predisposition to OUD, at least four single nucleotide polymorphisms in three genes are likely to have utility in predicting susceptibility. Additional studies with larger populations will need to be conducted to confirm these results before use in a clinical setting.

Keywords: Opioid use disorder (OUD), substance use disorder (SUD), single nucleotide polymorphisms (SNPs), genetic testing

\section{2 - INTRODUCTION}


Opioid use disorder (OUD) has reached epidemic proportions in America (Rudd et al., 2016; McBain et al., 2018). Non-medical use of opioid analgesics and heroin is on the rise (Fischer et al., 2014; Jordan et al., 2017; Pergolizzi et al., 2018). Opioid overdose is now the leading cause of death of people under 50 years old (Dowell et al., 2017). Mindful of these developments, many addiction researchers are focusing combatting the epidemic with prevention and treatment (Marshalek and Sullivan, 2010; Schmid et al., 2017a; Vashishtha et al., 2017; Ratycz et al., 2018). A shared aspiration is to obtain an individual's genetic "fingerprint" and identify whether they are at increased risk for developing OUD (e.g., ref. (Blum et al., 2018b)). Such testing is likely to interrogate several genes, as a multitude of factors ( $\mathrm{Lu}$ et al., 2003; Badiani and Robinson, 2004; Scherbaum and Specka, 2008; Valentine and Fraser, 2008; Ducci and Goldman, 2012; Kreek et al., 2012; Nielsen and Kreek, 2012; Mistry et al., 2014; Bawor et al., 2015; Curtis et al., 2017; Crist et al., 2018; Fonseca and Torrens, 2018) contribute to OUD predisposition. Several gene variations are associated with predisposition to OUD and/or OUD treatment response (Kreek et al., 2012; Bawor et al., 2015; Curtis et al., 2017; Crist et al., 2018; Fonseca and Torrens, 2018). Environmental factors also contribute to OUD (Lu et al., 2003; Badiani and Robinson, 2004; Scherbaum and Specka, 2008; Valentine and Fraser, 2008), and some environmental factors can affect the influence of genetic factors on predisposition to developing addiction (Ducci and Goldman, 2012). The ability to identify a priori individuals at increased OUD risk would help greatly in prevention. For instance, using opioid analgesics with these individuals could be avoided or strictly monitored.

West Virginia is the epicenter of this opioid crisis, leading in opioid-related overdose deaths (Seth et al., 2018). The state is also demographically homogenous (Gall et al., 2016)*, being predominantly whites (94\%) of European Caucasian ancestry (2010 US Census Data; http://censusviewer.com/state/WV). These factors make West Virginia ideal for genetic studies aimed at curbing the opioid epidemic. West Virginia University's Chestnut Ridge Center is home to a successful medication-assisted treatment program, known as the Comprehensive Opioid Addiction Treatment (COAT) clinic (Marshalek and Sullivan, 2010; Lander et al., 2013; Zheng et al., 2016; Zheng et al., 2017). Given access to this WV patient population, we sought to address 
whether there are single nucleotide polymorphisms (SNPs) more or less prevalent in WV persons with OUD than in the general population.

\section{3 - METHODS}

\subsection{1 - Recruitment}


60 volunteers, diagnosed with OUD using DSM-V criteria(Association, 2013), were recruited from WVU's COAT clinic under IRB 1506733605. All participants were patients of the COAT clinic in Morgantown, West Virginia. The COAT clinic's service area (and hence our research subject area) is geographically diverse, as it draws from the entire state.

\subsection{2 - Tissue Collection}

Consenting volunteers provided buccal swabs, which were placed in 15-ml conical centrifuge tubes (Corning) and stored at $-80^{\circ} \mathrm{C}$.

\subsection{3 - Genomic DNA Extraction}

DNA was extracted using QIAamp DNA Mini Kits according to manufacturer's protocol. Yield was assessed by measuring 260-nm absorbance of DNA extracts on a QIAxpert microfluidic reader. Purity was assessed by measuring 260-nm and 280-nm absorbance; all samples had a 260-nm/280-nm quotient greater than 1.8 units.

\subsection{4 - Genotyping}

Genotyping was performed using TaqMan (FisherSci \#4351379) primer-probe sets for each SNP (Table 1) and Type-it Fast SNP Probe PCR Kits (Qiagen) according to manufacturer's protocol. Samples were run on a RotorGene Q (Qiagen) in duplicate, and no-DNA negative controls were also performed for each TaqMan primerprobe set.

\subsection{5 - Statistical Analysis}

Allele frequencies were compared to those of 1006 individuals of European descent (1000 Genomes Project (Genomes Project et al., 2015)); if no information was available from the 1000 Genomes Project, allele 
frequencies were compared to ExAc database(Song et al., 2016) of $\sim 60,000$ genomes. Statistical analyses for differences of SNP variant frequency between groups were performed using Pearson's chi-square statistical test. The null hypothesis was that the allele frequencies from WV COAT clinic participants were the same as those from public databases. Therefore, $\mathrm{p}$-value $<0.05$ implies that the allele frequencies from WV COAT clinic participants are significantly different from the general public.

\section{4 - RESULTS}

A literature search for SNPs associated with OUD/SUD and/or related traits (e.g., anxiety) identified fourteen of known or suspected relevance to the biological actions of opioids (i.e., variations within genes encoding G protein-coupled receptors [the GPCRs dopamine $\mathrm{D}_{2}$ receptor (Blomqvist et al., 2000; Ikeda et al., 
2008), serotonin 5- $\mathrm{HT}_{2 \mathrm{~B}}$ receptor (Lin et al., 2004; Doly et al., 2008; Doly et al., 2009), and -opioid receptor (Oertel et al., 2012; Beer et al., 2013; Carpentier et al., 2013; Gong et al., 2013; Haerian and Haerian, 2013; Kolesnikov et al., 2013; Manini et al., 2013; Song et al., 2013; Cajanus et al., 2014; Solak et al., 2014; Xu et al., 2014; Adrian et al., 2015; Bartosova et al., 2015; Hancock et al., 2015; Laugsand et al., 2015; Olesen et al., 2015; Pfeifer et al., 2015; Wachman et al., 2015; Woodcock et al., 2015; Matic et al., 2016; Schwantes-An et al., 2016; Choi et al., 2017; Gao et al., 2017; Levran et al., 2017)]; Regulators of G protein Signaling [RGS2, RGS17] (Smoller et al., 2008; Amstadter et al., 2009b; Amstadter et al., 2009a; Koenen et al., 2009; Zhang et al., 2012; Dunn et al., 2014; Stein et al., 2014; Hohoff et al., 2015); a nerve growth factor [brain-derived neurotrophic factor] (Egan et al., 2003; de Cid et al., 2008); a voltage-gated potassium channel [KCNC1](Nascimento and Andrade, 2016); and, a second messenger-regulated transcription factor [cyclicAMP responsive element binding protein-1] (Pal et al., 2014); Table 1). We isolated buccal swabs from $60 \mathrm{WV}$ COAT clinic participants, prepared genomic DNA, and performed genotyping of the following SNPs.

2.4.1 - OPRM1 rs9479757 (mu opioid receptor gene variant) (Beer et al., 2013; Xu et al., 2014; Olesen et al., 2015)): $\mathrm{Xu}$ et al. ( $\mathrm{Xu}$ et al., 2014) identified rs9479757 as linked to heroin addiction severity among Han Chinese males; the G-to-A transition facilitates exon 2 skipping, leading to altered OPRM1 splice-variant mRNAs and encoded mu opioid receptor (MOR) isoforms. All sixty participants were heterozygous for OPRM1 rs9479757; in contrast, the minor allele frequency in the general European population is only 0.097 (Table 1).

2.4.2 - OPRM1 rs1799971 (mu opioid receptor gene variant) (Oertel et al., 2012; Carpentier et al., 2013; Gong et al., 2013; Haerian and Haerian, 2013; Kolesnikov et al., 2013; Manini et al., 2013; Song et al., 2013; Cajanus et al., 2014; Solak et al., 2014; Adrian et al., 2015; Bartosova et al., 2015; Hancock et al., 2015; Laugsand et al., 2015; Olesen et al., 2015; Pfeifer et al., 2015; Wachman et al., 2015; Woodcock et al., 2015; Matic et al., 2016; Schwantes-An et al., 2016; Choi et al., 2017; Gao et al., 2017; Levran et al., 2017)): Woodcock et al.(Woodcock et al., 2015) published that Caucasian male carriers of the non-synonymous 
OPRM1 rs1799971 minor allele (G) reported significantly more heroin use-related consequences and quit attempts, and were more likely to seek OUD treatment, than individuals homozygous for the ancestral A allele. Schwantes-An et al. (Schwantes-An et al., 2016), in a meta-analysis of $\sim 28,000$ Europeans, investigated nonspecific risk for SUD and compared cases dependent on any substance to controls not dependent on all assessed substances. The rs1799971 G allele showed a modest protective effect on general substance dependence (Schwantes-An et al., 2016). The rs1799971 G allele was significantly less frequent in WV COAT clinic participants than in the population at large, by a factor of $\sim 2$ (Table $1 ; 0.083 v s 0.162, \mathrm{p}=0.018$ ).

\section{[Location of Table 1]}

\subsection{3 - RGS2 rs4606 (Regulator of G protein Signaling-2 gene variant) (Smoller et al., 2008; Amstadter et} al., 2009b; Amstadter et al., 2009a; Koenen et al., 2009; Dunn et al., 2014; Stein et al., 2014; Hohoff et al., 2015)): One of us (Oliveira-Dos-Santos et al., 2000) previously reported that loss of RGS2 in mice engenders heightened anxiety and diminished aggression. Subsequently, Smoller et al. (Smoller et al., 2008) found that $R G S 2$ variations, including rs4606, were associated with introversion (a core personality trait in social anxiety disorder) (Smoller et al., 2008). Associations between the RGS2 SNP rs4606 and panic disorder (Hohoff et al., 2015), suicidal ideation (Amstadter et al., 2009b), post-traumatic stress disorder (Amstadter et al., 2009a), and generalized anxiety disorder (Koenen et al., 2009) have also been reported. We found that rs4606 was more frequent in COAT clinic volunteers than in the general population by a factor of $\sim 2$ (Table $1 ; 0.533 v s 0.276, \mathrm{p}$ $<0.001)$.

2.4.4 - HTR2B rs6736017 (serotonin [5-HT] receptor-2B gene) (Lin et al., 2004; Doly et al., 2008; Doly et al., 2009) variant): There are presently no published details on the HTR2B SNP rs6736017. However, HTR2B variations likely play a role in drug abuse. Doly et al. (Doly et al., 2008; Doly et al., 2009) showed that the serotonin $5-\mathrm{HT}_{2 \mathrm{~B}}$ receptor, encoded by the $H T R 2 B$ gene, is required for 3,4-methylene-dioxymethamphetamine 
(MDMA)-induced hyperlocomotion, serotonin and dopamine release, and conditioned place preference, the latter a rodent-based metric of reinforcing properties. Furthermore, Lin et al. (Lin et al., 2004) conducted a genome-scan identifying the human $H T R 2 B$ gene as a candidate for drug abuse liability. The $H T R 2 B$ SNP rs6736017 was markedly more frequent in COAT clinic participants than in the population at large, when comparing to the 60,000 genomes of the ExAc database (Table 1; $0.500 v s 0.0078, \mathrm{p}<0.01$ ).

None of the other 10 SNPs investigated exhibited a significantly different frequency in the COAT clinic volunteers versus the population at large (Table 1). 


\section{5 - DISCUSSION}

We identified four SNPs present at different frequencies in persons with OUD compared with a demographically-matched general population. It is currently difficult to quantify the degree of significance of each of these altered frequencies on OUD in the COAT population. One reason for this difficulty is that many gene variants are likely to play an integrated role in predisposition to OUD, and these variants may have additive or synergistic effects; here, we have only interrogated 14 SNPs in 8 candidate genes. Also, possible gene $\mathrm{x}$ environment effects were not assessed in the present study.

Two SNPs were in the OPRM1 gene encoding MOR -- the main molecular target for the euphoric effects of opioids, as well as for the therapeutic effects of buprenorphine (Marshalek and Sullivan, 2010; Zheng et al., 2017) and methadone in OUD treatment. Therefore, it is not surprising that $O P R M 1$ variations would be associated with OUD.

We also identified an $R G S 2$ variant associated with OUD. This finding is novel, but it is also not surprising. Opioids like oxycodone and buprenorphine generate neuronal signals by activating opioid-binding GPCRs, altering receptor conformation to cause nucleotide exchange (Siderovski and Willard, 2005) by the associated G protein heterotrimer (Galpha·GDP/Gbeta/Ggamma). GTP-loaded G-alpha then dissociates from the Gbeta/gamma heterodimer; both subunits become free to modulate enzymes that generate intracellular second messengers (e.g., cyclic AMP, calcium) or stimulate potassium channels, leading to neuronal membrane hyperpolarization and thus action potential inhibition. G-alpha proteins have intrinsic GTPase activity, leading to self-inactivation and reassociation with $\mathrm{G}_{\beta \gamma}$ subunits (Siderovski and Willard, 2005). RGS proteins like RGS2 greatly enhance the GTP hydrolysis rate of $\mathrm{G}_{\alpha}$ subunits (Ingi et al., 1998; Siderovski and Willard, 2005; Kimple et al., 2009), thereby inhibiting GPCR signaling. Thus, one might indeed expect that a polymorphism in an $R G S$ gene - encoding a negative regulator of GPCR signaling -- would be implicated in OUD. Moreover, $R G S 2$ function is particularly germane to multiple anxiety disorders (Smoller et al., 2008; Amstadter et al., 2009b; Amstadter et al., 2009a; Koenen et al., 2009; Dunn et al., 2014; Stein et al., 2014; Hohoff et al., 2015) that could predispose an individual toward OUD. 
$H T R 2 B$ encodes the serotonin $5-\mathrm{HT}_{2 \mathrm{~B}}$ receptor, implicated in the rewarding actions of MDMA (Doly et al., 2008; Doly et al., 2009) and cocaine (Doly et al., 2017), and thought to be involved in impulsivity (Bevilacqua et al., 2010) and resistance to antidepressants (Diaz et al., 2016), conditions that could predispose to OUD. Other polymorphisms in $H T R 2 B$ have also been associated with vulnerability to illegal drug use(Lin et al., 2004). Therefore, our identification of a $H T R 2 B$ polymorphism significantly more frequent in persons with OUD compared with a demographically-matched general population is not surprising.

There are several goals for identifying SNPs associated with OUD. One of these goals is to identify markers that, in genetic screens, could identify people at risk for developing OUD (e.g., before prescribing opioid analgesics). Another goal is to identify potential novel "druggable" targets for preventing and/or treating OUD. For instance, the published role of the 5-HT $2 \mathrm{~B}$ receptor in the actions of illicit drugs, coupled with our finding that rs6736017 is so frequent in OUD individuals, suggests that 5- $\mathrm{HT}_{2 \mathrm{~B}}$ receptor-active pharmaceuticals (of which many are already approved for human use) might have efficacy in preventing/treating OUD. Future studies with larger cohorts are required to validate our findings, both in West Virginia and in other, more demographically heterogeneous regions. Such studies should identify genes to interrogate in order to predict individuals with susceptibility to OUD/SUD and in doing so provide an opportunity for the prevention of the disease.

\section{Footnote:}

* Demographic homogeneity in West Virginia in no way reflects any heightened degree of consanguinity. Tincher (Tincher, 1980) examined 140 years' worth of marriage records in a remote four-county Appalachian region. While cousin marriage was found to occur in Appalachia, it was not conspicuously more prevalent than in other geographical locales: by 1970 , the cousin marriage rate was no higher than in the general U.S. population. 


\section{6 - TABLES}

2.6.1 Table 1. Genetic markers and minor allele frequency (MAF) data obtained from public databases (1000 Genomes Project and/orExAc) and WV COAT clinic patients $(\mathrm{N}=60)$ 


\begin{tabular}{|c|c|c|c|c|c|c|}
\hline \multicolumn{7}{|c|}{$\begin{array}{l}\text { Table 1. Genetic markers and minor allele frequency (MAF) data obtained from public } \\
\text { databases (1000 Genomes Project and/or ExAc) and WV COAT clinic patients }(\mathrm{N}=60) \text {. }\end{array}$} \\
\hline Gene & dbSNP ID & $\begin{array}{l}\text { Minor } \\
\text { Allele }\end{array}$ & $\begin{array}{c}\text { TaqMan } \\
\text { Probe } \\
\end{array}$ & $\begin{array}{c}\text { MAF via } 1000 \\
\text { Genomes* }\end{array}$ & $\begin{array}{c}\text { MAF via } \\
\text { ExAc }{ }^{\dagger}\end{array}$ & $\begin{array}{l}\text { MAF from } \\
\text { COAT clinic }\end{array}$ \\
\hline OPRMI & rs9479757 & A & C_25472011_10 & 0.097 & 0.082 & $\begin{aligned} \mathbf{0 . 5 0 0} & \\
\mathbf{p} & <\mathbf{0 . 0 0 1}\end{aligned}$ \\
\hline OPRMI & rs 1799971 & $\mathrm{G}$ & C_8950074_1 & 0.162 & 0.185 & $\begin{array}{c}0.083 \\
p=0.018\end{array}$ \\
\hline$R G S 2$ & rs4606 & $\mathrm{G}$ & C_2498717_10 & 0.276 & n.a. & $\begin{aligned} & 0.533 \\
\mathbf{p} & <0.001\end{aligned}$ \\
\hline$H T R 2 B$ & rs6736017 & $\mathrm{C}$ & C_25614588_20 & n.a. & 0.0078 & $\begin{aligned} & \mathbf{0 . 5 0 0} \\
\mathbf{p} & <0.001\end{aligned}$ \\
\hline OPRMI & rs2075572 & $\mathrm{G}$ & C_1691815_1 & 0.413 & n.a. & $\begin{array}{c}0.483 \\
\mathrm{p}=0.12\end{array}$ \\
\hline$R G S 17$ & rs596359 & $\mathrm{T}$ & C_7830523_10 & 0.517 & n.a. & $\begin{array}{c}0.467 \\
\mathrm{p}=0.27\end{array}$ \\
\hline $\begin{array}{l}D R D 2 / \\
A N K K 1\end{array}$ & rs 1800497 & A & C_7486676_10 & 0.188 & 0.256 & $\begin{array}{c}0.217 \\
p=0.41\end{array}$ \\
\hline$D R D 2$ & rs 1799978 & $\mathrm{C}$ & C_7486599_20 & 0.060 & n.a. & $\begin{array}{c}0.075 \\
\mathrm{p}=0.44\end{array}$ \\
\hline$B D N F$ & rs6265 & $\mathrm{T}$ & C_11592758_10 & 0.197 & 0.194 & $\begin{array}{c}0.167 \\
\mathrm{p}=0.49\end{array}$ \\
\hline$K C N C 1$ & rs60349741 & $\mathrm{C}$ & C_89088414_10 & 0.001 & n.a. & 0.000 \\
\hline$H T R 2 B$ & rs77982984 & $\mathrm{A}$ & C_99996051_10 & 0.003 & 0.0012 & 0.000 \\
\hline$H T R 2 B$ & rs78484969 & $\mathrm{C}$ & C_99996081_10 & $\begin{array}{c}0.001 \\
(\mathrm{~N}=1030 \text { Finns })\end{array}$ & n.a. & 0.000 \\
\hline$H T R 2 B$ & rs77570025 & $\mathrm{G}$ & C_99996068_10 & 0.006 & 0.002 & 0.000 \\
\hline CREB1 & rs35349697 & $\mathrm{A}$ & C_25636228_10 & n.a. & 0.000008 & 0.000 \\
\hline
\end{tabular}

* Minor allele frequency reported on $\mathrm{N}=1006$ Europeans via 1000 Genomes (except as otherwise noted); n.a. = not available.

$\dagger$ Minor allele frequence reported on $\mathrm{N} \sim 60,000$ people via ExAc database of the Broad Institute; n.a. $=$ not available.

* p-value, denoting significance of difference between MAFs, is derived by comparison between WV COAT clinic and European (if not, then ExAc) MAF using binomial test (null hypothesis is "no difference between WV COAT patients and Europeans"; alternative is "there is difference between WV COAT patients and Europeans")

\section{7 - References}

Adrian M, Kiff C, Glazner C, Kohen R, Tracy JH, Zhou C, McCauley E and Vander Stoep A (2015) Examining gene-environment interactions in comorbid depressive and disruptive behavior disorders using a Bayesian approach. J Psychiatr Res 68:125-133. 
Amstadter AB, Koenen KC, Ruggiero KJ, Acierno R, Galea S, Kilpatrick DG and Gelernter J (2009a) Variant in RGS2 moderates posttraumatic stress symptoms following potentially traumatic event exposure. $J$ Anxiety Disord 23:369-373.

Amstadter AB, Koenen KC, Ruggiero KJ, Acierno R, Galea S, Kilpatrick DG and Gelernter J (2009b) Variation in RGS2 is associated with suicidal ideation in an epidemiological study of adults exposed to the 2004 Florida hurricanes. Arch Suicide Res 13:349-357.

Association AP (2013) Diagnostic and Statistical Manual of Mental Disorders. American Psychiatric Association Publishing.

Badiani A and Robinson TE (2004) Drug-induced neurobehavioral plasticity: the role of environmental context. Behav Pharmacol 15:327-339.

Bartosova O, Polanecky O, Perlik F, Adamek S and Slanar O (2015) OPRM1 and ABCB1 polymorphisms and their effect on postoperative pain relief with piritramide. Physiol Res 64 Suppl 4:S521-527.

Bawor M, Dennis BB, Tan C, Pare G, Varenbut M, Daiter J, Plater C, Worster A, Marsh DC, Steiner M, Anglin R, Desai D, Thabane L and Samaan Z (2015) Contribution of BDNF and DRD2 genetic polymorphisms to continued opioid use in patients receiving methadone treatment for opioid use disorder: an observational study. Addict Sci Clin Pract 10:19.

Beer B, Erb R, Pavlic M, Ulmer H, Giacomuzzi S, Riemer Y and Oberacher H (2013) Association of polymorphisms in pharmacogenetic candidate genes (OPRD1, GAL, ABCB1, OPRM1) with opioid dependence in European population: a case-control study. PLoS One 8:e75359.

Bevilacqua L, Doly S, Kaprio J, Yuan Q, Tikkanen R, Paunio T, Zhou Z, Wedenoja J, Maroteaux L, Diaz S, Belmer A, Hodgkinson CA, Dell'osso L, Suvisaari J, Coccaro E, Rose RJ, Peltonen L, Virkkunen M and Goldman D (2010) A population-specific HTR2B stop codon predisposes to severe impulsivity. Nature 468:1061-1066.

Blomqvist O, Gelernter J and Kranzler HR (2000) Family-based study of DRD2 alleles in alcohol and drug dependence. Am J Med Genet 96:659-664. 
Blum K, Chen ALC, Thanos PK, Febo M, Demetrovics Z, Dushaj K, Kovoor A, Baron D, Smith DE, Roy AK, III, Fried L, Chen TJH, Chapman E, Sr., Modestino EJ, Steinberg B and Badgaiyan RD (2018) Genetic addiction risk score (GARS), a predictor of vulnerability to opioid dependence. Front Biosci (Elite Ed) 10:175-196.

Cajanus K, Kaunisto MA, Tallgren M, Jokela R and Kalso E (2014) How much oxycodone is needed for adequate analgesia after breast cancer surgery: effect of the OPRM1 118A>G polymorphism. J Pain 15:1248-1256.

Carpentier PJ, Arias Vasquez A, Hoogman M, Onnink M, Kan CC, Kooij JJ, Makkinje R, Iskandar S, Kiemeney LA, de Jong CA, Franke B and Buitelaar JK (2013) Shared and unique genetic contributions to attention deficit/hyperactivity disorder and substance use disorders: a pilot study of six candidate genes. Eur Neuropsychopharmacol 23:448-457.

Choi SW, Lam DMH, Wong SSC, Shiu HHC, Wang AXM and Cheung CW (2017) Effects of Single Nucleotide Polymorphisms on Surgical and Postsurgical Opioid Requirements: A Systematic Review and Meta-Analysis. Clin J Pain 33:1117-1130.

Crist RC, Clarke TK and Berrettini WH (2018) Pharmacogenetics of Opioid Use Disorder Treatment. CNS Drugs 32:305-320.

Curtis K, Viswanath H, Velasquez KM, Molfese DL, Harding MJ, Aramayo E, Baldwin PR, Ambrosi E, Madan A, Patriquin M, Frueh BC, Fowler JC, Kosten TR, Nielsen DA and Salas R (2017) Increased habenular connectivity in opioid users is associated with an alpha5 subunit nicotinic receptor genetic variant. $A m J$ Addict 26:751-759.

de Cid R, Fonseca F, Gratacos M, Gutierrez F, Martin-Santos R, Estivill X and Torrens M (2008) BDNF variability in opioid addicts and response to methadone treatment: preliminary findings. Genes Brain Behav 7:515-522. 
Diaz SL, Narboux-Neme N, Boutourlinsky K, Doly S and Maroteaux L (2016) Mice lacking the serotonin 5HT2B receptor as an animal model of resistance to selective serotonin reuptake inhibitors antidepressants. Eur Neuropsychopharmacol 26:265-279.

Doly S, Bertran-Gonzalez J, Callebert J, Bruneau A, Banas SM, Belmer A, Boutourlinsky K, Herve D, Launay JM and Maroteaux L (2009) Role of serotonin via 5-HT2B receptors in the reinforcing effects of MDMA in mice. PLoS One 4:e7952.

Doly S, Quentin E, Eddine R, Tolu S, Fernandez SP, Bertran-Gonzalez J, Valjent E, Belmer A, Vinals X, Callebert J, Faure P, Meye FJ, Herve D, Robledo P, Mameli M, Launay JM, Maldonado R and Maroteaux L (2017) Serotonin 2B Receptors in Mesoaccumbens Dopamine Pathway Regulate Cocaine Responses. J Neurosci 37:10372-10388.

Doly S, Valjent E, Setola V, Callebert J, Herve D, Launay JM and Maroteaux L (2008) Serotonin 5-HT2B receptors are required for 3,4-methylenedioxymethamphetamine-induced hyperlocomotion and 5-HT release in vivo and in vitro. $J$ Neurosci 28:2933-2940.

Dowell D, Arias E, Kochanek K, Anderson R, Guy GP, Jr., Losby JL and Baldwin G (2017) Contribution of Opioid-Involved Poisoning to the Change in Life Expectancy in the United States, 2000-2015. JAMA 318:1065-1067.

Ducci F and Goldman D (2012) The genetic basis of addictive disorders. Psychiatr Clin North Am 35:495-519. Dunn EC, Solovieff N, Lowe SR, Gallagher PJ, Chaponis J, Rosand J, Koenen KC, Waters MC, Rhodes JE and Smoller JW (2014) Interaction between genetic variants and exposure to Hurricane Katrina on posttraumatic stress and post-traumatic growth: a prospective analysis of low income adults. J Affect Disord 152-154:243-249.

Egan MF, Kojima M, Callicott JH, Goldberg TE, Kolachana BS, Bertolino A, Zaitsev E, Gold B, Goldman D, Dean M, Lu B and Weinberger DR (2003) The BDNF val66met polymorphism affects activitydependent secretion of BDNF and human memory and hippocampal function. Cell 112:257-269. 
Fischer B, Keates A, Buhringer G, Reimer J and Rehm J (2014) Non-medical use of prescription opioids and prescription opioid-related harms: why so markedly higher in North America compared to the rest of the world? Addiction 109:177-181.

Fonseca F and Torrens M (2018) Pharmacogenetics of Methadone Response. Mol Diagn Ther 22:57-78.

Gall BJ, Wilson A, Schroer AB, Gross JD, Stoilov P, Setola V, Watkins CM and Siderovski DP (2016) Genetic variations in GPSM3 associated with protection from rheumatoid arthritis affect its transcript abundance. Genes Immun 17:139-147.

Gao X, Wang Y, Lang M, Yuan L, Reece AS and Wang W (2017) Contribution of Genetic Polymorphisms and Haplotypes in DRD2, BDNF, and Opioid Receptors to Heroin Dependence and Endophenotypes Among the Han Chinese. OMICS 21:404-412.

Genomes Project C, Auton A, Brooks LD, Durbin RM, Garrison EP, Kang HM, Korbel JO, Marchini JL, McCarthy S, McVean GA and Abecasis GR (2015) A global reference for human genetic variation. Nature 526:68-74.

Gong XD, Wang JY, Liu F, Yuan HH, Zhang WY, Guo YH and Jiang B (2013) Gene polymorphisms of OPRM1 A118G and ABCB1 C3435T may influence opioid requirements in Chinese patients with cancer pain. Asian Pac J Cancer Prev 14:2937-2943.

Haerian BS and Haerian MS (2013) OPRM1 rs1799971 polymorphism and opioid dependence: evidence from a meta-analysis. Pharmacogenomics 14:813-824.

Hancock DB, Levy JL, Gaddis NC, Glasheen C, Saccone NL, Page GP, Hulse GK, Wildenauer D, Kelty EA, Schwab SG, Degenhardt L, Martin NG, Montgomery GW, Attia J, Holliday EG, McEvoy M, Scott RJ, Bierut LJ, Nelson EC, Kral AH and Johnson EO (2015) Cis-Expression Quantitative Trait Loci Mapping Reveals Replicable Associations with Heroin Addiction in OPRM1. Biol Psychiatry 78:474-484.

Hohoff C, Weber H, Richter J, Domschke K, Zwanzger PM, Ohrmann P, Bauer J, Suslow T, Kugel H, Baumann C, Klauke B, Jacob CP, Fritze J, Bandelow B, Gloster AT, Gerlach AL, Kircher T, Lang T, Alpers GW, Strohle A, Fehm L, Wittchen HU, Arolt V, Pauli P, Hamm A, Reif A and Deckert J (2015) 
RGS2 ggenetic variation: association analysis with panic disorder and dimensional as well as intermediate phenotypes of anxiety. Am J Med Genet B Neuropsychiatr Genet 168B:211-222.

Ikeda M, Yamanouchi Y, Kinoshita Y, Kitajima T, Yoshimura R, Hashimoto S, O'Donovan MC, Nakamura J, Ozaki N and Iwata N (2008) Variants of dopamine and serotonin candidate genes as predictors of response to risperidone treatment in first-episode schizophrenia. Pharmacogenomics 9:1437-1443.

Ingi T, Krumins AM, Chidiac P, Brothers GM, Chung S, Snow BE, Barnes CA, Lanahan AA, Siderovski DP, Ross EM, Gilman AG and Worley PF (1998) Dynamic regulation of RGS2 suggests a novel mechanism in G-protein signaling and neuronal plasticity. $J$ Neurosci 18:7178-7188.

Jordan AE, Blackburn NA, Des Jarlais DC and Hagan H (2017) Past-year prevalence of prescription opioid misuse among those 11 to 30 years of age in the United States: A systematic review and meta-analysis. $J$ Subst Abuse Treat 77:31-37.

Kimple AJ, Soundararajan M, Hutsell SQ, Roos AK, Urban DJ, Setola V, Temple BR, Roth BL, Knapp S, Willard FS and Siderovski DP (2009) Structural determinants of G-protein alpha subunit selectivity by regulator of G-protein signaling 2 (RGS2). J Biol Chem 284:19402-19411.

Koenen KC, Amstadter AB, Ruggiero KJ, Acierno R, Galea S, Kilpatrick DG and Gelernter J (2009) RGS2 and generalized anxiety disorder in an epidemiologic sample of hurricane-exposed adults. Depress Anxiety 26:309-315.

Kolesnikov Y, Gabovits B, Levin A, Veske A, Qin L, Dai F and Belfer I (2013) Chronic pain after lower abdominal surgery: do catechol-O-methyl transferase/opioid receptor mu-1 polymorphisms contribute? Mol Pain 9:19.

Kreek MJ, Levran O, Reed B, Schlussman SD, Zhou Y and Butelman ER (2012) Opiate addiction and cocaine addiction: underlying molecular neurobiology and genetics. $J$ Clin Invest 122:3387-3393.

Lander LR, Marshalek P, Yitayew M, Ford D, Sullivan CR and Gurka KK (2013) Rural healthcare disparities: challenges and solutions for the pregnant opioid-dependent population. $W V$ Med $J$ 109:22-27. 
Laugsand EA, Skorpen F, Kaasa S, Sabatowski R, Strasser F, Fayers P and Klepstad P (2015) Genetic and Nongenetic Factors Associated With Constipation in Cancer Patients Receiving Opioids. Clin Transl Gastroenterol 6:e90.

Levran O, Peles E, Randesi M, da Rosa JC, Adelson M and Kreek MJ (2017) The mu-opioid receptor nonsynonymous variant $118 \mathrm{~A}>\mathrm{G}$ is associated with prolonged abstinence from heroin without agonist treatment. Pharmacogenomics 18:1387-1391.

Lin Z, Walther D, Yu XY, Drgon T and Uhl GR (2004) The human serotonin receptor 2B: coding region polymorphisms and association with vulnerability to illegal drug abuse. Pharmacogenetics 14:805-811.

Lu L, Shepard JD, Hall FS and Shaham Y (2003) Effect of environmental stressors on opiate and psychostimulant reinforcement, reinstatement and discrimination in rats: a review. Neurosci Biobehav Rev 27:457-491.

Manini AF, Jacobs MM, Vlahov D and Hurd YL (2013) Opioid receptor polymorphism A118G associated with clinical severity in a drug overdose population. J Med Toxicol 9:148-154.

Marshalek PJ and Sullivan CR (2010) Buprenorphine clinics: an integrated and multidisciplinary approach to treating opioid dependence. $W V$ Med $J$ 106:60-63.

Matic M, van den Bosch GE, de Wildt SN, Tibboel D and van Schaik RH (2016) Genetic variants associated with thermal pain sensitivity in a paediatric population. Pain 157:2476-2482.

McBain R, Rose AJ and LaRochelle MR (2018) The U.S. opioid epidemic: One disease, diverging tales. Prev Med 112:176-178.

Mistry CJ, Bawor M, Desai D, Marsh DC and Samaan Z (2014) Genetics of Opioid Dependence: A Review of the Genetic Contribution to Opioid Dependence. Curr Psychiatry Rev 10:156-167.

Nascimento FA and Andrade DM (2016) Myoclonus epilepsy and ataxia due to potassium channel mutation (MEAK) is caused by heterozygous KCNC1 mutations. Epileptic Disord 18:135-138.

Nielsen DA and Kreek MJ (2012) Common and specific liability to addiction: approaches to association studies of opioid addiction. Drug Alcohol Depend 123 Suppl 1:S33-41. 
Oertel BG, Doehring A, Roskam B, Kettner M, Hackmann N, Ferreiros N, Schmidt PH and Lotsch J (2012)

Genetic-epigenetic interaction modulates mu-opioid receptor regulation. Hum Mol Genet 21:4751-4760.

Olesen AE, Sato H, Nielsen LM, Staahl C, Droney J, Gretton S, Branford R, Drewes AM, Arendt-Nielsen L, Riley J and Ross J (2015) The genetic influences on oxycodone response characteristics in human experimental pain. Fundam Clin Pharmacol 29:417-425.

Oliveira-Dos-Santos AJ, Matsumoto G, Snow BE, Bai D, Houston FP, Whishaw IQ, Mariathasan S, Sasaki T, Wakeham A, Ohashi PS, Roder JC, Barnes CA, Siderovski DP and Penninger JM (2000) Regulation of T cell activation, anxiety, and male aggression by RGS2. Proc Natl Acad Sci U S A 97:12272-12277.

Pal A, Chakraborty J and Das S (2014) Association of CREB1 gene polymorphism with drug seeking behaviour in eastern Indian addicts. Neurosci Lett 570:53-57.

Pergolizzi JV, Jr., LeQuang JA, Taylor R, Jr., Raffa RB and Group NR (2018) Going beyond prescription pain relievers to understand the opioid epidemic: the role of illicit fentanyl, new psychoactive substances, and street heroin. Postgrad Med 130:1-8.

Pfeifer P, Sariyar M, Eggermann T, Zerres K, Vernaleken I, Tuscher O and Fehr C (2015) Alcohol Consumption in Healthy OPRM1 G Allele Carriers and Its Association with Impulsive Behavior. Alcohol Alcohol 50:379-384.

Ratycz MC, Papadimos TJ and Vanderbilt AA (2018) Addressing the growing opioid and heroin abuse epidemic: a call for medical school curricula. Med Educ Online 23:1466574.

Rudd RA, Seth P, David F and Scholl L (2016) Increases in Drug and Opioid-Involved Overdose Deaths United States, 2010-2015. MMWR Morb Mortal Wkly Rep 65:1445-1452.

Scherbaum N and Specka M (2008) Factors influencing the course of opiate addiction. Int J Methods Psychiatr Res 17 Suppl 1:S39-44.

Schmid CL, Kennedy NM, Ross NC, Lovell KM, Yue Z, Morgenweck J, Cameron MD, Bannister TD and Bohn LM (2017) Bias Factor and Therapeutic Window Correlate to Predict Safer Opioid Analgesics. Cell 171:1165-1175 e1113. 
Schwantes-An TH, Zhang J, Chen LS, Hartz SM, Culverhouse RC, Chen X, Coon H, Frank J, Kamens HM,

Konte B, Kovanen L, Latvala A, Legrand LN, Maher BS, Melroy WE, Nelson EC, Reid MW, Robinson JD, Shen PH, Yang BZ, Andrews JA, Aveyard P, Beltcheva O, Brown SA, Cannon DS, Cichon S, Corley RP, Dahmen N, Degenhardt L, Foroud T, Gaebel W, Giegling I, Glatt SJ, Grucza RA, Hardin J, Hartmann AM, Heath AC, Herms S, Hodgkinson CA, Hoffmann P, Hops H, Huizinga D, Ising M, Johnson EO, Johnstone E, Kaneva RP, Kendler KS, Kiefer F, Kranzler HR, Krauter KS, Levran O, Lucae S, Lynskey MT, Maier W, Mann K, Martin NG, Mattheisen M, Montgomery GW, MullerMyhsok B, Murphy MF, Neale MC, Nikolov MA, Nishita D, Nothen MM, Nurnberger J, Partonen T, Pergadia ML, Reynolds M, Ridinger M, Rose RJ, Rouvinen-Lagerstrom N, Scherbaum N, Schmal C, Soyka M, Stallings MC, Steffens M, Treutlein J, Tsuang M, Wall TL, Wodarz N, Yuferov V, Zill P, Bergen AW, Chen J, Cinciripini PM, Edenberg HJ, Ehringer MA, Ferrell RE, Gelernter J, Goldman D, Hewitt JK, Hopfer CJ, Iacono WG, Kaprio J, Kreek MJ, Kremensky IM, Madden PA, McGue M, Munafo MR, Philibert RA, et al. (2016) Association of the OPRM1 Variant rs1799971 (A118G) with Non-Specific Liability to Substance Dependence in a Collaborative de novo Meta-Analysis of European-Ancestry Cohorts. Behav Genet 46:151-169.

Seth P, Scholl L, Rudd RA and Bacon S (2018) Overdose Deaths Involving Opioids, Cocaine, and Psychostimulants - United States, 2015-2016. MMWR Morb Mortal Wkly Rep 67:349-358.

Siderovski DP and Willard FS (2005) The GAPs, GEFs, and GDIs of heterotrimeric G-protein alpha subunits. Int J Biol Sci 1:51-66.

Smoller JW, Paulus MP, Fagerness JA, Purcell S, Yamaki LH, Hirshfeld-Becker D, Biederman J, Rosenbaum JF, Gelernter J and Stein MB (2008) Influence of RGS2 on anxiety-related temperament, personality, and brain function. Arch Gen Psychiatry 65:298-308.

Solak O, Erdogan MO, Yildiz H, Ulasli AM, Yaman F, Terzi ES, Ulu S, Dundar U and Solak M (2014) Assessment of opioid receptor mul gene A118G polymorphism and its association with pain intensity in patients with fibromyalgia. Rheumatol Int 34:1257-1261. 
Song W, Gardner SA, Hovhannisyan H, Natalizio A, Weymouth KS, Chen W, Thibodeau I, Bogdanova E, Letovsky S, Willis A and Nagan N (2016) Exploring the landscape of pathogenic genetic variation in the ExAC population database: insights of relevance to variant classification. Genet Med 18:850-854.

Song Z, Du B, Wang K and Shi X (2013) Effects of OPRM1 A118G polymorphism on epidural analgesia with fentanyl during labor: a meta-analysis. Genet Test Mol Biomarkers 17:743-749.

Stein MB, Keshaviah A, Haddad SA, Van Ameringen M, Simon NM, Pollack MH and Smoller JW (2014) Influence of RGS2 on sertraline treatment for social anxiety disorder. Neuropsychopharmacology 39:1340-1346.

Tincher RB (1980) Night Comes to the Chromosomes: Inbreeding and Population Genetics in Southern Appalachia. Central Issues in Anthropology 2:27-49.

Valentine K and Fraser S (2008) Trauma, damage and pleasure: rethinking problematic drug use. Int J Drug Policy 19:410-416.

Vashishtha D, Mittal ML and Werb D (2017) The North American opioid epidemic: current challenges and a call for treatment as prevention. Harm Reduct $J$ 14:7.

Wachman EM, Hayes MJ, Sherva R, Brown MS, Davis JM, Farrer LA and Nielsen DA (2015) Variations in opioid receptor genes in neonatal abstinence syndrome. Drug Alcohol Depend 155:253-259.

Woodcock EA, Lundahl LH, Burmeister M and Greenwald MK (2015) Functional mu opioid receptor polymorphism (OPRM1 A(118) G) associated with heroin use outcomes in Caucasian males: A pilot study. Am J Addict 24:329-335.

Xu J, Lu Z, Xu M, Pan L, Deng Y, Xie X, Liu H, Ding S, Hurd YL, Pasternak GW, Klein RJ, Cartegni L, Zhou W and Pan YX (2014) A heroin addiction severity-associated intronic single nucleotide polymorphism modulates alternative pre-mRNA splicing of the mu opioid receptor gene OPRM1 via hnRNPH interactions. J Neurosci 34:11048-11066.

Zhang H, Wang F, Kranzler HR, Anton RF and Gelernter J (2012) Variation in regulator of G-protein signaling 17 gene (RGS17) is associated with multiple substance dependence diagnoses. Behav Brain Funct 8:23. 
Zheng W, Nickasch M, Lander L, Wen S, Xiao M, Marshalek P, Dix E and Sullivan C (2017) Treatment

Outcome Comparison Between Telepsychiatry and Face-to-face Buprenorphine Medication-assisted

Treatment for Opioid Use Disorder: A 2-Year Retrospective Data Analysis. J Addict Med 11:138-144.

Zheng WH, Wakim RJ, Geary RC, Lander LR, Wen SJ, Xiao MC and Sullivan CR (2016) Self-reported Sleep

Improvement in Buprenorphine MAT (Medication Assisted Treatment) Population. Austin J Drug Abuse Addict 3.

\section{Chapter Three}

Preclinical testing of nalfurafine as an opioid-sparing adjuvant that potentiates analgesia by the mu opioid receptor-targeting agonist morphine

Shane W. Kaski ${ }^{1}$, Joshua D. Gross ${ }^{1}$, Kristen R. Trexler ${ }^{2}$, Kim Wix $^{1}$, Aubrie A. Harland ${ }^{3}$, Thomas E. Prisinzano ${ }^{3}$, Jeffrey Aubé ${ }^{4}$, Steven G. Kinsey ${ }^{2}$, Terry Kenakin ${ }^{5}$, David P. Siderovski ${ }^{1}$, and Vincent Setola ${ }^{1,6}$

Department of Physiology \& Pharmacology, West Virginia University School of Medicine, Morgantown, WV, United States (S.W.K., J.D.G., K.W., D.P.S., V.S.)

Department of Psychology, West Virginia University Eberly College of Arts and Sciences, Morgantown, WV, United States (K.R.T, S.G.K.)

Department of Medicinal Chemistry, The University of Kansas School of Pharmacy, Lawrence, KS, United States (T.E.P.)

Division of Chemical Biology and Medicinal Chemistry, The University of North Carolina Eshelman School of Pharmacy, Chapel Hill, NC, United States (A.A.H, J.A.)

Department of Pharmacology, The University of North Carolina School of Medicine, Chapel Hill, NC, United States (T.K.) 
Departments of Neuroscience, and Behavioral Medicine \& Psychiatry, West Virginia University School of Medicine, Morgantown, WV, United States (V.S.) 


\section{1 - Abstract:}

mu opioid receptor (MOR)-targeting analgesics are efficacious pain treatments, but notorious for their abuse potential. In animal models, co-administration of traditional kappa opioid receptor (KOR)-targeting agonists with MOR-targeting analgesics can decrease reward and potentiate analgesia. However, traditional KORtargeting agonists are well known for inducing anti-therapeutic side effects (psychotomimesis, depression, anxiety, dysphoria). Recent data suggest that some functionally selective or "biased" KOR-targeting agonists might retain the therapeutic effects of KOR activation without inducing undesirable side effects. Nalfurafine, used safely in Japan since 2009 for uremic pruritus, is one such functionally selective KOR-targeting agonist. Here we quantify the bias of nalfurafine and several other KOR agonists against the unbiased reference standard U50,488 and show that nalfurafine demonstrates a significant $\mathrm{G}$ protein-signaling bias. While nalfurafine $(0.015$ $\mathrm{mg} / \mathrm{kg}$ ) produces spinal analgesia (via a tail-immersion test) equivalent to $5 \mathrm{mg} / \mathrm{kg}$ of U50,488, it significantly enhances the analgesic effect of $5 \mathrm{mg} / \mathrm{kg}$ morphine in the hot plate assay. In addition, $0.015 \mathrm{mg} / \mathrm{kg}$ nalfurafine does not produce conditioned place aversion (CPA) yet retains the ability to reduce morphine-induced conditioned place preference (CPP) in C57BL/6J mice. Nalfurafine did produce robust inhibition of both spontaneous and morphine-stimulated locomotor behavior, however, suggesting a persistence of sedative effects when co-administered with morphine. Taken together, these findings suggest that G protein-biased KOR agonists may produce greater analgesic augmentation than unbiased agonists when combined with traditional opioid analgesics, while also reducing opioid-induced reward with less risk of dysphoria. Thus, adjuvant administration of $\mathrm{G}$ protein-biased KOR agonists may be beneficial in enhancing the therapeutic potential of MOR-targeting drugs, such as morphine. 


\section{2 - Introduction}

Opioid use disorder (OUD) is an American health crisis (Manchikanti et al., 2012; Koh, 2015; Volkow and Collins, 2017). Use of prescription opioids, such as morphine and oxycodone, has contributed significantly to the OUD problem (Jones, 2013a). Morphine, the prototypical opioid analgesic, is a mainstay for treating moderate to severe pain as may occur post-operatively or in chronic illness. While prescription opioids are effective painkillers, there currently exists no facile way to use them for extended periods of time without the prospect of inducing tolerance, dependence and, in many cases, addiction. One plausible solution is to use morphine (and other MOR-targeting analgesics) in a way that increases its analgesic effects, thereby requiring lower doses (an approach known as "dose sparing"), or in a way that reduces addictive potential. In this vein, if the anti-nociceptive potential of MOR-targeting analgesics could be enhanced via an adjuvant that does not induce therapeutically limiting side effects, then their continued therapeutic use in treating pain could be extended.

kappa opioid receptor (KOR)-targeting agonists, when given with MOR-targeting analgesics, not only produce additive analgesia (Sutters et al., 1990; Negus et al., 2008b; Briggs and Rech, 2009), reduced tolerance (He and Lee, 1997; Khotib et al., 2004), and reduced respiratory depression (Verborgh et al., 1997) but can also reduce the rewarding properties of MOR-targeting analgesics (Kuzmin et al., 1997; Tsuji et al., 2001; Tao et al., 2006). However, clinical use of some KOR agonists, such as ketocyclazocine (Kumor et al., 1986) or salvinorin A (MacLean et al., 2013), has largely failed due to poor tolerability. In rodents, traditional KOR agonists produce anxiety- and depressive-like behaviors (Carlezon et al., 2006; Bruchas et al., 2009; Ehrich et al., 2015a), as well as locomotor suppression (Kunihara et al., 1993; Narita et al., 1993; Ehrich et al., 2015a; Brust et al., 2016b). In humans, the highly selective KOR agonist salvinorin A produces similar therapeutically limiting effects (MacLean et al., 2013; Maqueda et al., 2015; Johnson et al., 2016).

Thus, it is not surprising that initial enthusiasm for KOR agonists as adjuvants to MOR-targeting analgesics was reduced by early preclinical and clinical findings using single applications of mixed MOR/KOR agonists. For example, while nalbuphine studies in rodents demonstrated reduced conditioned place preference (CPP) to 
morphine and enhanced morphine-induced analgesia (Tao et al., 2006), human studies demonstrated dosedependent increases in dysphoria (Jasinski and Mansky, 1972; Preston et al., 1989a; Walsh and Babalonis, 2017). Similarly, pentazocine and butorphanol also induce classic dysphoric effects of traditional KORtargeting agonists in humans, especially at higher doses (Preston et al., 1987; Zacny et al., 1994; Greenwald and Stitzer, 1998; Walsh et al., 2008; Walsh and Babalonis, 2017), limiting their therapeutic potential.

Recent efforts to develop non-addictive opioids however, have renewed interest in KOR ligands with specific emphasis on developing functionally selective (or "biased") KOR agonists (Urban et al., 2007; Rankovic et al., 2016). G protein-biased KOR agonists demonstrate reduced potencies for signaling through the GRK/ $\beta$-arrestin pathway (Bohn and Aube, 2017). While G protein-dependent signaling through KOR is well established as producing the primary therapeutic outcome of analgesia (Chavkin, 2011; Brust et al., 2016b; Schattauer et al., 2017), the role of GRK/ $\beta$-arrestin signaling in producing dysphoria downstream of KOR activation is less clear. Some have shown that aversive behavior toward KOR agonists requires GRK3 (and p38 MAPK) activation (Bruchas et al., 2007b; Chavkin et al., 2014; Ehrich et al., 2015a), while others have observed little effect of Arrb2 ( -arrestin-2) genetic ablation on the aversion produced by a variety of KOR agonists (White et al., 2015). Recent work with triazole 1.1 (Brust et al., 2016b), however, and nalfurafine (Liu et al., 2018) suggests that these G protein-biased KOR agonists may lack dysphoric effects at doses that produce analgesia, supporting the role of $\beta$-arrestin signaling in the dysphoric effects of traditional KOR agonists. G protein-biased KOR agonists may, thus, present a strategy for reducing the rewarding properties of MORtargeting analgesics while avoiding the pitfalls of traditional KOR agonists. This notion is supported by a recent preclinical study in rats (Townsend et al., 2017b) showing that nalfurafine reduces intravenous selfadministration of the MOR-targeting analgesic oxycodone while also potentiating its analgesic effect.

Nalfurafine is a $\mathrm{G}$ protein functionally selective KOR-targeting agonist with high translational potential given its safe usage in Japan since 2009 to treat uremic pruritis and, importantly, does not produce psychotomimesis (Inui, 2015). Therefore, we aimed to assess the therapeutic efficacy of nalfurafine in both 
potentiating the analgesic effect and reducing the rewarding properties and of the MOR-targeting analgesic morphine, while also assessing the biased signaling properties of nalfurafine both in vitro and in vivo. 


\section{3 - Methods:}

\subsection{1 - Animal Subjects}

All experiments were conducted using male and female C57BL/6J mice (RRID: IMSR_JAX:000664) between 8-14 weeks of age and 17-35 g; the sexes were used in similar proportions across all experiments. Original breeding pairs were obtained from The Jackson Laboratory (Bar Harbor, ME). All procedures were carried out in accordance with the National Research Council's Guide to the Care and Use of Laboratory Animals (Eighth Edition), and were approved by West Virginia University's Institutional Animal Care and Use Committee.

\subsection{2 - Study Design}

Mice were randomly assigned to treatment conditions, after being balanced for sex. Mice were acclimated to the test room for at least 30 min prior to any study. All mice were used for a single experimental assay. Sample size for each experiment was determined by power analysis using effect sizes derived from literature, power value of 0.8 , and an alpha value of 0.05 . All experiments were done by personnel who were blinded to treatment conditions.

\subsection{3 - Drugs}

( \pm ) U50,488, GR 89696, and ICI 199,441 were all purchased from Tocris Biosciences (Minneapolis, MN). Nalfurafine hydrochloride was purchased from Medchem Express (Monmouth Junction, NJ). Morphine sulfate salt pentahydrate was purchased from Sigma Aldrich (St. Louis, MO). Salvinorin A, ethoxymethyl ether Sal B (EOM Sal B), and triazole 1.1 were prepared as previously described (Zhou et al., 2013; Ewald et al., 2017a). All drugs were dissolved in $100 \%$ DMSO and diluted in saline to the desired concentration (no DMSO concentration exceeded $5 \% \mathrm{v} / \mathrm{v}$ final). In drug combination experiments, nalfurafine was injected subcutaneously (sc) as described in the limited literature available regarding this compound's use in mice (Endoh et al., 1999; Tsuji et al., 2001; Liu et al., 2018), while U50,488 and morphine were delivered by intraperitoneal (ip) injection as commonly described (Rada et al., 1996; McLaughlin et al., 2006; Koo et al., 2012; Muschamp et al., 2012; Laman-Maharg et al., 2017; Robinson et al., 2017). Dose range for nalfurafine 
and U50,488 were chosen based upon the place preference data in the literature (Tsuji et al., 2001; Land et al., 2009b; Ehrich et al., 2015b). Dose range for morphine was chosen to produce consistent place preference while allowing for high sensitivity to detect potentiation in the hot plate assay of analgesia (Mueller et al., 2002; Raehal and Bohn, 2011)

\subsection{4 - Measurement of Signaling Bias}

Quantification of G protein signaling dependent changes in intracellular cyclic AMP (cAMP) levels was conducted using a GloSensor luciferase-based assay in HEK293T cells transiently transfected with $5 \mu \mathrm{g}$ of KOR expression vector DNA (3xHA-hKOR; www.cDNA.org) and $5 \mu \mathrm{g}$ of pGloSensor-22F cAMP biosensor expression vector DNA (Promega, Madison, WI). Quantification of $\beta$-arrestin recruitment was conducted using the luciferase-based TANGO assay (Barnea et al., 2008; Allen et al., 2011) in HTLA cells (generously provided by Dr. Gilad Barnea) transiently transfected with $5 \mu \mathrm{g}$ of KOR-V2-TEV-tTA expression vector DNA (Addgene plasmid \#66462 donated by Dr. Bryan Roth). The appropriate masses of expression vector DNAs transfected was empirically determined prior to acquisition of the data contained herein. Transfections were performed in 10-cm dishes using the calcium phosphate-based method (Jordan et al., 1996). Culture media was replaced 16 hrs after transfection, and cells then plated on 96-well plates approximately $24 \mathrm{hrs}$ after transfection. All cells were serum-starved with 1\% dialyzed serum-containing medium for 8-16 hrs before assaying. For assays of cAMP inhibition, medium was replaced with GloSesnor detection reagent dissolved in HEPES (20 mM)buffered Hank's balanced saline solution, and cells were incubated for 2 hrs at room temperature. KORselective agonists were applied for $15 \mathrm{~min}$ prior to a 15 -min stimulation with $100 \mathrm{nM}$ isoproterenol (to induce endogenous $\beta$-adrenergic receptor-mediated and $\mathrm{G \alpha}_{\mathrm{s}}$-dependent production of cAMP) and subsequent quantification of luminescence. For TANGO assays of $\beta$-arrestin recruitment, drug stimulation was performed overnight in $1 \%$ dialyzed serum-containing medium. Medium was removed the following morning, the cells lysed with BrightGlo reagent (Promega), and luminescence quantified using a FlexStation 3 multi-mode plate reader (Molecular Devices). 


\subsection{5 - Calculation of Bias Factor}

Bias factors were calculated using the method previously described (Kenakin, 2017). Briefly, $\log \left(\mathrm{E}_{\max } / \mathrm{EC}_{50}\right)$ values for both GloSensor and TANGO assays were separately generated for each ligand using potency $\left(\mathrm{EC}_{50}\right)$ and maximal efficacy $\left(\mathrm{E}_{\max }\right)$ values obtained from these assays. $\Delta \log \left(\mathrm{E}_{\max } / \mathrm{EC}_{50}\right)$ was calculated in each assay as the difference in $\log \left(\mathrm{E}_{\max } / \mathrm{EC}_{50}\right)$ for each ligand from the reference ligand (the unbiased $\mathrm{KOR}$ agonist U50,488). $\Delta \Delta \log \left(\mathrm{E}_{\max } / \mathrm{EC}_{50}\right)$ was then calculated as the difference in $\Delta \log \left(\mathrm{E}_{\max } / \mathrm{EC}_{50}\right)$ between GloSensor and TANGO assays for each ligand. The 95\% confidence interval (CI) for each bias factor was calculated using the $\mathrm{E}_{\max }$ and $\mathrm{EC}_{50}$ values generated in individual experiments for each ligand in each assay.

\subsection{6 - Warm Water Tail Withdrawal}

The warm water tail withdrawal test was conducted as described previously (Schattauer et al., 2017). Briefly, mice were gently wrapped in cloth before immersing the distal $2 \mathrm{~cm}$ of the tail in $55^{\circ} \mathrm{C}$ water and recording the latency for the mouse to withdraw its tail from the water. Baseline latencies were recorded $30 \mathrm{~min}$ after administration of vehicle. Mice were then injected with drug and latencies were recorded after $30 \mathrm{~min}$. A maximum cutoff of $10 \mathrm{~s}$ was used to avoid tissue damage. Data are presented as latency to tail-withdrawal in seconds as well as percent maximum possible effect (\%MPE) following the equation: \%MPE $=$ (latency baseline $) /(10 \mathrm{sec}$ - baseline $) * 100 \%)$.

\subsection{7 - Hot Plate Analgesia Test}

To assess integrated pain perception, the hot plate test of nociception was performed as described previously (Raehal and Bohn, 2011) with minor modification. Nociceptive latency after vehicle injection was measured on Day 1. On Day 2, mice were injected with drug and response latencies were measured after $30 \mathrm{~min}$. Individual mice were placed onto a $53^{\circ} \mathrm{C}$ hot plate (IITC Life Science Inc.; Woodland Hills, CA) inside of a clear, open-bottom acrylic cylinder. A maximum cutoff of $30 \mathrm{~s}$ was used to avoid tissue damage. Time until the first nociceptive sign (i.e., licking of the hind paw, flicking of the hind paw, or jumping) was recorded by a trained observer to the nearest $0.1 \mathrm{sec}$ and reported as percent maximum possible effect $(\% \mathrm{MPE}=$ 
(latency - baseline) / (30 sec - baseline) * 100\%). Data were analyzed by one way ANOVA with a Tukey’s post hoc test, using Prism 7 software.

\subsection{8 - Locomotion}

Locomotor activity was assessed using a 16 X 16 open-field infrared photobeam activity system (PAS) from San Diego Instruments (San Diego, CA), as described previously (Gross et al., 2018). Briefly, locomotion was quantified as total beam breaks in the $x$ and $y$ coordinates in five minute bins. Spontaneous locomotion was assessed by administering drug or vehicle immediately before placing the mouse in the locomotor chamber for 60 min. Morphine-induced locomotion was assessed in a three-day procedure. On Day 1, mice were habituated to the locomotor chamber for $60 \mathrm{~min}$. On Day 2, mice were habituated to the locomotor chamber for $30 \mathrm{~min}$ before receiving an injection of vehicle and returning to the chamber for an additional 60 min. On Day 3, mice were habituated to the locomotor chamber for $30 \mathrm{~min}$ before receiving an injection of either morphine with vehicle or morphine with KOR agonist, and returning to the chamber for an additional 60 min. Data plotted over time were normalized to the average vehicle locomotion in the first 5 minute bin for novelty induced locomotion and to the average locomotion of each subject during the $30 \mathrm{~min}$ prior to injection for morphine suppressed locomotion. For total novelty locomotion, data are normalized to the average total locomotor activity of the vehicle condition over the full 60 minute trial. For total morphine stimulated locomotion, data are normalized to the average total locomotor activity during the 60 minutes post vehicle injection on day 2 .

\subsection{9 - Conditioned Place Preference/Aversion}

CPP and CPA studies were conducted as described previously (Redila and Chavkin, 2008) with the following modifications. A two-chambered place preference apparatus with differential floor grating in the white and black chambers was used. Baseline preference was established on Day 1 by allowing the mouse free access to both chambers for $30 \mathrm{~min}$ (for U50,488 studies) or $50 \mathrm{~min}$ (for nalfurafine studies, given prior evidence of time-of-effect for this compound (Tsuji et al., 2001)) and recording the amount of time spent in each chamber. The conditioning phase occurred on days 2 and 3 in 30 min (U50,488) or 50 min (nalfurafine) sessions. Vehicle was administered in the AM session and drug in the PM session with a 4-hr interval between 
sessions. For CPP, drug was administered in the least-preferred chamber to override the initial preference of the mouse. Drug was administered in the most-preferred chamber for CPA. Preference was assessed on Day 4 by allowing the mouse free access to both chambers for $30 \mathrm{~min}(\mathrm{U} 50,488)$ or 50 (nalfurafine) min, and recording the amount of time spent in each chamber. ANY-maze video tracking software (Stoelting Co., Wood Dale, IL) was used to track movement and time spent in each chamber. Data are presented as the difference in time spent in the drug-paired chamber for each mouse. Data were analyzed by two-way ANOVA with Dunnett's post hoc test to compare to vehicle controls and Sidak's post hoc test to compare across genotypes, each run using Prism 7 software (GraphPad).

\section{4 - Results}

\subsection{1 - Selection of nalfurafine as KOR biased agonist under consideration as a possible morphine adjuvant}


Before launching our assessment of the efficacy of G protein-biased KOR agonists in reducing the addictive properties of morphine, we characterized the signaling properties of a variety of KOR-specific compounds to identify a suitable biased KOR agonist. Utilizing a GloSensor-based cAMP assay to determine G protein signaling, and the TANGO assay to determine $\beta$-arrestin recruitment, we identified EOM-salvinorin B (Bias Factor $=15.26,+95 \% \mathrm{CI}=29.95,-95 \% \mathrm{CI}=7.78)$ and nalfurafine $($ Bias Factor $=7.73,+95 \% \mathrm{CI}=15.16$, $-95 \% \mathrm{CI}=3.94)$ as strongly $\mathrm{G}$ protein-biased KOR agonists (Figure 1), the latter consistent with prior findings (Schattauer et al., 2017). As nalfurafine has been used successfully for nearly a decade in Japanese patients for the treatment of uremic pruritus (Ueno et al., 2013; Inui, 2015), we chose it as our biased KOR agonist given its greater translational potential as a viable pharmaceutical adjuvant.

\subsection{2 - Spinal anti-nociception by nalfurafine}

To establish the level of analgesia to be expected from these doses of nalfurafine, we assessed their abilities in the mouse tail immersion test (relative to the unbiased KOR agonist U50,488) to produce spinal antinociception, an outcome of KOR agonism known to be G protein-dependent. Tail withdrawal latencies were analyzed by one-way ANOVA: $F(6,152)=29.97, \mathrm{p}<0.0001$. All doses of nalfurafine produced significant increases in withdrawal latency compared to vehicle (Figure 2; $<<0.0001$ for each; Dunnett's post hoc test). Administration of $1.25 \mathrm{mg} / \mathrm{kg}$ and $5 \mathrm{mg} / \mathrm{kg}$ U50,488 also increased tail withdrawal latency compared to vehicle (Figure 4; $\mathrm{p}<0.001$ and $\mathrm{P}<0.0001$ respectively), while no significant difference was observed between 2.5 $\mathrm{mg} / \mathrm{kg}$ U50,488 and vehicle (Holm-sidak post hoc test, $\mathrm{p}>0.05$ ), though $5 \mathrm{mg} / \mathrm{kg}$ was significantly higher than $2.5 \mathrm{mg} / \mathrm{kg}$ U50,488 (Holm-sidak post hoc test, $\mathrm{p}<0.05$ ). No significant difference was observed between 1.25 $\mathrm{mg} / \mathrm{kg}$ and $5 \mathrm{mg} / \mathrm{kg} \mathrm{U} 50,488$ (Holm-sidak post hoc test, ( $>>0.05$ ). Both $0.015 \mathrm{mg} / \mathrm{kg}$ and $0.03 \mathrm{mg} / \mathrm{kg} \mathrm{doses}$ of nalfurafine elicited comparable anti-nociception to $5 \mathrm{mg} / \mathrm{kg} \mathrm{U} 50,488$ (Holm-Sidak post hoc test, $\mathrm{p}=0.613$ for both).

\subsection{3 - Enhancement of morphine-induced supraspinal analgesia by nalfurafine co-administration}

To assess the effect of KOR agonism on the integrated nociceptive response, we assessed the effect of nalfurafine co-administration on morphine-induced analgesia via the hot plate test. Nociceptive latency with 
administration of U50,488 was analyzed by one-way ANOVA: $F(6,57)=4.798, p=0.0005$. Nociceptive latency with administration of nalfurafine was also analyzed by one-way ANOVA: $F(6,68)=31.80, p<0.0001$. We found that no dose of U50,488 nor nalfurafine produced a significant analgesic response on its own in the hot plate assay of nociception (Figure 5; Sidak's post hoc test, $\mathrm{p}>0.05$ ). Co-administration of $2.5 \mathrm{mg} / \mathrm{kg}$ U50,488 with 5 $\mathrm{mg} / \mathrm{kg}$ morphine significantly increased analgesia compared to U50,488 alone (Holm-Sidak's post hoc test, $\mathrm{p}<$ 0.01; Figure 5A), but this level of analgesia was not significantly different from $5 \mathrm{mg} / \mathrm{kg}$ morphine alone (Holm-Sidak's post hoc test, $\mathrm{p}>0.05$; Figure 5A).

Co-administration of all doses of nalfurafine tested with $5 \mathrm{mg} / \mathrm{kg}$ morphine significantly increased analgesia compared to nalfurafine alone (Holm-Sidak's post hoc test, $\mathrm{p}<0.0001$; Figure $5 \mathrm{~B}$ ) and $5 \mathrm{mg} / \mathrm{kg}$ morphine alone (Holm-Sidak's post hoc test, $\mathrm{p}<0.0001$ for 0.015 and $0.06 \mathrm{mg} / \mathrm{kg}$ nalfurafine co-admin; $\mathrm{p}<0.001$ for $0.03 \mathrm{mg} / \mathrm{kg}$ nalfurafine co-admin, Figure 5B) .

\subsection{4 - Locomotor suppression by nalfurafine administration and co-administration}

Open-field locomotion represents a behavioral outcome of mesolimbic dopamine release and is increased by movement of mice into a novel environment, as well as by administration of many drugs of abuse to mice (Bardo et al., 1990; Sellings and Clarke, 2003; Bromberg-Martin et al., 2010; Fields and Margolis, 2015). Traditional KOR agonists suppress both spontaneous as well as opioid analgesic-induced locomotion (Narita et al., 1993; Chefer et al., 2005; Bruijnzeel, 2009). Suppression of total novelty-induced locomotion was analyzed by one-way ANOVA: $\mathrm{F}(6,104)=18.01 ; \mathrm{p}<0.0001$. We found that total spontaneous locomotion was significantly reduced upon administration of 2.5 and $5 \mathrm{mg} / \mathrm{kg} \mathrm{U} 50,488$ ( $\mathrm{p}<0.05$ and $\mathrm{p}<0.01$ respectively), as well as $0.015,0.03$ and $0.06 \mathrm{mg} / \mathrm{kg}$ nalfurafine $(\mathrm{p}<0.001$, and $\mathrm{p}<0.0001$ respectively) compared to vehicle (Dunnett's post hoc test; Figure 6A and inset). The dose of $0.06 \mathrm{mg} / \mathrm{kg}$ nalfurafine elicited a significantly greater reduction in spontaneous locomotion, as compared to $1.25,2.5$ or $5 \mathrm{mg} / \mathrm{kg} \mathrm{U} 50,488$ ( $\mathrm{p}<0.0001, \mathrm{p}<0.001$, and $\mathrm{p}<0.0001$ respectively), or 0.015 and $0.03 \mathrm{mg} / \mathrm{kg}$ nalfurafine ( $<<0.05, \mathrm{p}<0.01$ respectively); Tukey's post hoc test; Figure 6A and inset). No significant differences in locomotor suppression were seen between doses of 
U50,488 (Tukey's post hoc test, $\mathrm{p} \geq 0.4698$ ), nor between $5 \mathrm{mg} / \mathrm{kg}$ U50,488 and 0.015 or $0.03 \mathrm{mg} / \mathrm{kg}$ nalfurafine (Tukey's post hoc test, $\mathrm{p}=0.9336$ and $\mathrm{p}=0.9480$, respectively).

Modulation of total morphine-stimulated locomotion by U50,488 was analyzed by one-way ANOVA: $\mathrm{F}(3,32)=6.142, \mathrm{p}=0.0020$. Modulation by nalfurafine was also analyzed by one-way ANOVA: $\mathrm{F}(3,27)=30.11$, $\mathrm{p}<0.0001$. Suppression of locomotion was seen with co-administration of $5 \mathrm{mg} / \mathrm{kg}$ morphine with $5 \mathrm{mg} / \mathrm{kg}$ U50,488 (Dunnett's post hoc test, $\mathrm{p}<0.01$; Figure 6D and inset), as well as with all doses of nalfurafine (Dunnett's post hoc test, $\mathrm{p}<0.0001$; Figure $6 \mathrm{E}$ and inset).

\subsection{5 - Dose-dependent conditioned place aversion by nalfurafine}

To help assess the level of anti-therapeutic liability presented by nalfurafine, we measured its ability to produce conditioned place aversion in mice (Figure 3), a behavior linked to $\beta$-arrestin signaling downstream of KOR activation (Bruchas et al., 2007b; Ehrich et al., 2015a) and a therapeutically-limiting effect of traditional KOR agonists like U50,488 (Jasinski and Mansky, 1972; Preston and Bigelow, 1993; Siebert, 1994; Greenwald and Stitzer, 1998). U50,488-induced CPA was analyzed by two-way ANOVA: test day effect, $F(1,39)=20.41$, $\mathrm{p}<0.0001$; treatment effect, $\mathrm{F}(3,39)=8.940, \mathrm{p}=0.0001$; interaction effect, $\mathrm{F}(3,39)=4.684$, $\mathrm{p}=0.0072$; subject effect, $\mathrm{F}(39,39)=0.8332, \mathrm{p}=0.7143$. Nalfurafine-induced CPA was also analyzed by two-way ANOVA: test day effect, $\mathrm{F}(1,50)=13.04, \mathrm{p}=0.0007$; treatment effect, $\mathrm{F}(3,50)=2.302$, $\mathrm{p}=0.0884$; interaction effect, $\mathrm{F}(3,50)=2.572$, $\mathrm{p}=0.0645$; subjects effect, $\mathrm{F}(50,50)=0.9840, \mathrm{p}=0.5227 \mathrm{We}$ found that all doses of $\mathrm{U} 50,488$ produced aversion compared to vehicle (Dunnett's post hoc test, $1.25 \mathrm{mg} / \mathrm{kg}=\mathrm{p}<0.05,2.5 \mathrm{mg} / \mathrm{kg}=\mathrm{p}<0.001$, and $5 \mathrm{mg} / \mathrm{kg}=$ $\mathrm{p}<0.01$ Figure $3 \mathrm{~A}$ ) with no significant difference between doses (Holm-Sidak post hoc test, $\mathrm{p}>0.05$ ) while only the $0.03 \mathrm{mg} / \mathrm{kg}$ dose of nalfurafine produced statistically significant aversion compared to vehicle (Dunnett's post hoc test, $\mathrm{p}<0.01$; Figure $3 \mathrm{~B}$ ) with no significant difference between doses (Holm-sidak post hoc test, $\mathrm{p}>0.05)$.

\subsection{6 - Modulation of morphine-induced conditioned place preference by nalfurafine}

As unbiased KOR agonists have been observed, when co-administered, to reduce the rewarding properties of various drugs of abuse, including morphine (Kuzmin et al., 1997; Tao et al., 2006), we evaluated the ability 
of nalfurafine co-administration in mice to reduce the conditioned place preference produced by morphine. U50,488 results were analyzed by two-way ANOVA: test day effect, $F(1,78)=218.2$, $p<0.0001$; treatment effect, $\mathrm{F}(3,78)=0.8699, \mathrm{p}=0.4604$; interaction effect, $\mathrm{F}(3,78)=3.482$, $\mathrm{p}=0.0197$; subject effect, $\mathrm{F}(78,78)=1.032$, $\mathrm{p}=0.4441$. Morphine alone $(5 \mathrm{mg} / \mathrm{kg})$ produced place preference compared to preconditioning (Sidak post hoc test, $\mathrm{p}<0.0001$; Figure 2). U50,488 co-administration (at $1.25 \mathrm{mg} / \mathrm{kg}$ and $5 \mathrm{mg} / \mathrm{kg}$ ) reduced preference for morphine (Dunnett post hoc test, $\mathrm{p}<0.05$; Figure 2A), though there was no significant difference between doses (Holm-Sidak post hoc test, $\mathrm{p}>0.05)$. Nalfurafine results were also analyzed by two-way ANOVA: test day effect, $\mathrm{F}(1,85)=169, \mathrm{p}<0.0001$; treatment effect, $\mathrm{F}(3,85)=5.049$, $\mathrm{p}=0.0029$; interaction effect, $\mathrm{F}(3,85)=1.209$, $\mathrm{p}=0.3116$; subjects effect, $\mathrm{F}(85,85)=0.9096, \mathrm{p}=0.6683$. Nalfurafine co-administration showed no effect on morphine-induced preference at $0.03 \mathrm{mg} / \mathrm{kg}$, but produced a significant reduction in morphine preference at $0.015 \mathrm{mg} / \mathrm{kg}$ and $0.06 \mathrm{mg} / \mathrm{kg}$, with $0.06 \mathrm{mg} / \mathrm{kg}$ being significantly different from $0.03 \mathrm{mg} / \mathrm{kg}$ nalfurafine coadministration. Dunnett post hoc test, $\mathrm{p}<0.05, \mathrm{p}<0.01$ and Holm-Sidak post hoc test, $\mathrm{p}<0.05$, respectively; Figure 2B).

\section{5 - Discussion}

Our results support nalfurafine as a G protein-biased KOR agonist that can beneficially modulate both the analgesic and rewarding properties of morphine in vivo upon co-administration; however, nalfurafine also

produced aversion and locomotor suppression in mice. KOR agonists reduce reward associated with drugs of abuse (Lindholm et al., 2001; Morani et al., 2009a; Townsend et al., 2017b); however, their clinical viability has been hampered by dysphoria in patients (Jasinski and Mansky, 1972; Preston and Bigelow, 1993; Siebert, 1994; Greenwald and Stitzer, 1998). The dysphoria produced by KOR agonism has been linked to signaling 
downstream of $\beta$-arrestin mobilization (Bruchas et al., 2007b; Ehrich et al., 2015a) and, thus, G protein-biased KOR agonists may lack dysphoric properties (Brust et al., 2016b; Liu et al., 2018). Our data demonstrate that while nalfurafine retains the ability to produce conditioned place aversion, the augmentation of morphine's analgesic effect persists at lower doses, providing evidence that G protein-biased KOR agonists may have increased clinical utility as dose-sparing agents compared to unbiased KOR agonists. Proper dose combinations may provide augmented analgesia while avoiding dysphoria and minimizing sedation.

Initial in vitro screening identified both nalfurafine and EOM Sal-B as potent and significantly G-protein biased KOR agonists. We chose to focus our initial efforts on nalfurafine due to its greater translational potential, being used safely in Japan since 2009 (Inui, 2015).

We first assessed spinal nociception utilizing the warm water tail withdrawal assay. As previous studies demonstrate that KOR agonist-induced increases in withdrawal latency are G protein-signaling dependent (Hernandez et al., 1995; Berg et al., 2011; White et al., 2015; Abraham et al., 2018), this assay also allowed for comparison of in vivo G protein-signaling between nalfurafine and U50 at the selected doses. A dose of $5 \mathrm{mg} / \mathrm{kg}$ U50,488 produced analgesia that was statistically equivalent to both 0.015 and $0.03 \mathrm{mg} / \mathrm{kg}$ nalfurafine. This finding suggests that KOR-mediated G protein signaling is equivalent in vivo between the higher dose of U50,488 and the lowest tested doses of nalfurafine.

As the supraspinal analgesia produced by MOR-targeting analgesics represents a major factor in their clinical success (Kanjhan, 1995; Jensen, 1997), we next assessed the effect of co-administration in a nonreflexive assay of nociception. While no significant analgesic effect of U50,488 or nalfurafine alone was observed in the hot plate assay compared to morphine alone, there was a significant effect of nalfurafine upon co-administration with morphine (Figure 5B). This increased analgesic effect was not seen with coadministration of U50,488. One potential explanation of this effect is that the locomotor-suppressing property of nalfurafine (Figure 6) hinders the expression of nociceptive behaviors (e.g., jumping or paw flicking/licking), thereby falsely increasing nociceptive latency measurements. In the assay of morphine stimulated locomotion however, $5 \mathrm{mg} / \mathrm{kg}$ U50,488 suppresses locomotion to a similar extent as both 0.015 and $0.03 \mathrm{mg} / \mathrm{kg}$ (Figure 6), 
yet only nalfurafine co-administration is seen to elicit augmented analgesia (Figure 5B). These findings make a locomotor confound to nociception measurement less likely. In this light, future studies are planned to investigate the effects of nalfurafine and MOR agonist co-administration on pain-suppressed behaviors to further investigate the potential confound and better characterize the analgesic interactions of these two drugs.

As $5 \mathrm{mg} / \mathrm{kg}$ U50,488 and $0.15 \mathrm{mg} / \mathrm{kg}$ nalfurafine produced equivalent increases in tail withdrawal latencies, the increased analgesic effect seen in the hot plate with co-administration of nalfurafine may indicate a beneficial supra-spinal or spinal interaction between morphine and nalfurafine downstream of $\mathrm{G}$ proteinsignaling at KOR. Early work with site specific administration of MOR and KOR agonists demonstrate analgesic synergism when given intrathecally (i.t.) but not intracerebroventricularly (i.c.v.) (Ren et al., 1985; Sutters et al., 1990; Miaskowski et al., 1992; Miaskowski et al., 1993), suggesting that while KOR-dependent spinal analgesia is equivalent between 0.015 nalfurafine and $5 \mathrm{mg} / \mathrm{kg} \mathrm{U} 50,488$, the biased signaling profile of nalfurafine produces a greater analgesic interaction between MOR and KOR signaling.

To assess the potential clinical viability of this co-administration paradigm, we evaluated these doses of nalfurafine and U50,488 for sedation and dysphoria. In the present study, significant reductions in spontaneous locomotion were seen with all KOR agonists tested except $1.25 \mathrm{mg} / \mathrm{kg}$ U50,488. This observation of sedation persisted when these KOR agonists were co-administered with morphine. However, post-marketing surveillance of nalfurafine reports a low incidence of somnolence (1\%), at doses safe and efficacious in human patients (Kozono et al., 2018), suggesting that sedation may not necessarily prove to be an anti-therapeutic effect of nalfurafine co-administration with a MOR-targeting analgesic.

To assess dysphoria, we utilized the CPA assay. Aversion to KOR agonists has been linked to signaling downstream of B-arrestin (Bruchas et al., 2007b; Ehrich et al., 2015a) and previous work has demonstrated a lack of CPA to nalfurafine (Tsuji et al., 2001; Liu et al., 2018). In our CPA assays with nalfurafine, only 0.03 $\mathrm{mg} / \mathrm{kg}$ produced significant aversion, as compared to U50,488 which produced significant aversion at all doses tested. The observed decrease in aversion with the highest dose of KOR agonist has been demonstrated in a 
previous study (Robles et al., 2014) and could reflect the appearance of cognitive deficits (Castellano et al., 1988; Carey et al., 2009).

Of note is the finding that $0.03 \mathrm{mg} / \mathrm{kg}$ nalfurafine produced significant aversion. This result is supported by recent work demonstrating that the G protein biased KOR agonist RB-64 produces aversion in both wild-type and $\beta$-arrestin-2 knockout mice (in addition to the unbiased KOR agonists U69,593 and salvinorin A (White et al., 2015)), suggesting that aversion to KOR agonists may be produced in part through mechanisms independent of $\beta$-arrestin-dependent signaling. G protein-biased KOR agonists might thus retain the ability to produce aversion, though less potently than unbiased agonists.

Lastly, KOR agonists are known to reduce the rewarding properties of a variety of drugs of abuse (Kuzmin et al., 1997; Lindholm et al., 2001; Tsuji et al., 2001; Tao et al., 2006; Morani et al., 2009a; Ewald et al., 2017a; Townsend et al., 2017a), presenting a second possible benefit of combination therapy. Using the CPP assay, we found that nalfurafine reduces the rewarding properties of $5 \mathrm{mg} / \mathrm{kg}$ morphine at 0.015 and 0.06 $\mathrm{mg} / \mathrm{kg}$, while $0.03 \mathrm{mg} / \mathrm{kg}$ produced no effect on morphine place preference. Though a dose of $0.03 \mathrm{mg} / \mathrm{kg}$ reduced morphine CPP in a previous study, a potential source of this difference could be our use of inbred C57BL/6J mice, as opposed to the use of outbred ddY male mice (Tsuji et al., 2001). Indeed, strain differences in response to KOR agonists, as well as to psychostimulant drugs of abuse, have previously been demonstrated (e.g., (Castellano et al., 1988; Mouri et al., 2012)).

Administration of U50,488 displayed a similar pattern, with doses of 1.25 and $5 \mathrm{mg} / \mathrm{kg}$ suppressing morphine place preference, while $2.5 \mathrm{mg} / \mathrm{kg}$ was not a statistically significant suppression. Similar to results seen in CPA, the reduction in morphine induced CPP at the highest doses of each KOR agonist may be explained in part by cognitive disruption preventing the effective pairing of stimulus with context. Effects seen with the low and middle dose of each drug were opposite of expected. Interestingly, the doses of both drugs producing the greatest level of aversion produced the least suppression of morphine induced CPP. While extensive work focuses on KOR agonists effects on cocaine CPP (Suzuki et al., 1992; Redila and Chavkin, 2008; Morani et al., 2009b), less work investigates their effects on opioid-analgesic induced CPP, with few if 
any using multiple doses of KOR agonist. Outside of the work by Tsuji et al. referenced earlier, a related lab demonstrated that $1 \mathrm{mg} / \mathrm{kg}$ U50,488 reduced CPP to $5 \mathrm{mg} / \mathrm{kg}$ morphine, though other doses of U50,488 were not assessed (Masahiko et al., 1993). A drawback of the CPP procedure is its relatively low sensitivity to dose magnitude (Napier et al., 2013), making dose-response relationships difficult to properly establish, however the effects reported here indicate an interaction between the dose of KOR agonist and the rewarding properties of morphine. As pretreatment with U50,488 has been shown to increase CPP to cocaine, it is possible that differences in the timing of KOR agonist effects at different doses in relation to the rewarding effects of morphine play a role in the observed response pattern. A more detailed interrogation of the effects seen in CPP with an expanded dose range and varied pretreatment intervals could aid in determining the pharmacodynamic and pharmacokinetic factors involved.

Taken together, these data suggest that G protein-biased KOR agonists may be effective dose-sparing adjuvants for traditional MOR-targeting analgesics. As all doses of nalfurafine provided similar augmentation of morphine's analgesic effect, low doses may provide adequate analgesic synergism while avoiding dysphoria and sedation. Nalfurafine is used in the treatment of uremic pruritis at doses that produce low rates of sedation, insomnia, constipation, psychosis and other common KOR related side-effects (Kozono et al., 2018). The antipruritic dose in rodents extends as low as $5 \mu \mathrm{g} / \mathrm{kg}$ (Liu et al., 2018). As a dose of $0.015 \mathrm{mg} / \mathrm{kg}$ effectively reduces morphine CPP without significant aversion, it is possible that doses already used in human subjects to treat pruritis may produce the benefits of co-administration described herein while avoiding significant antitherapeutic effects. Though the signaling pathways involved in both the intended and unintended effects of KOR agonism requires further investigation, the reduced side-effect profile of nalfurafine as compared with unbiased KOR agonists suggests that G protein-biased KOR agonists may be clinically relevant adjuvants for opioid-based pain therapies, particularly in acute in-patient settings. Additional studies are planned to investigate the effects of chronic co-administration on analgesic tolerance, withdrawal and reward related behaviors. 


\section{Acknowledgements}

We thank Dr. Gilad Barnea (Brown University) for furnishing HTLA cells for TANGO assays, and Dr. Liz Engler-Chiurazzi for access to, and advice with, the WVU Rodent Behavioral Core facility.

\section{Funding}

This work was supported, in part, by the E.J. Van Liere Medicine Professor Endowment (to D.P.S.) and by NIDA research grants R01 DA018151 (to T.E.P.) and R03 DA039335 (to S.G.K). J.D.G. and S.W.K. each acknowledge prior support from an NIGMS Behavioral \& Biomedical Sciences training grant [T32 GM081741] and current support from NIDA predoctoral NRSA fellowships [F31 DA043331 and F30 DA044711, respectively].

3.6 - Figures

\subsubsection{Nalfurafine is a potent $G$ protein biased KOR agonist}



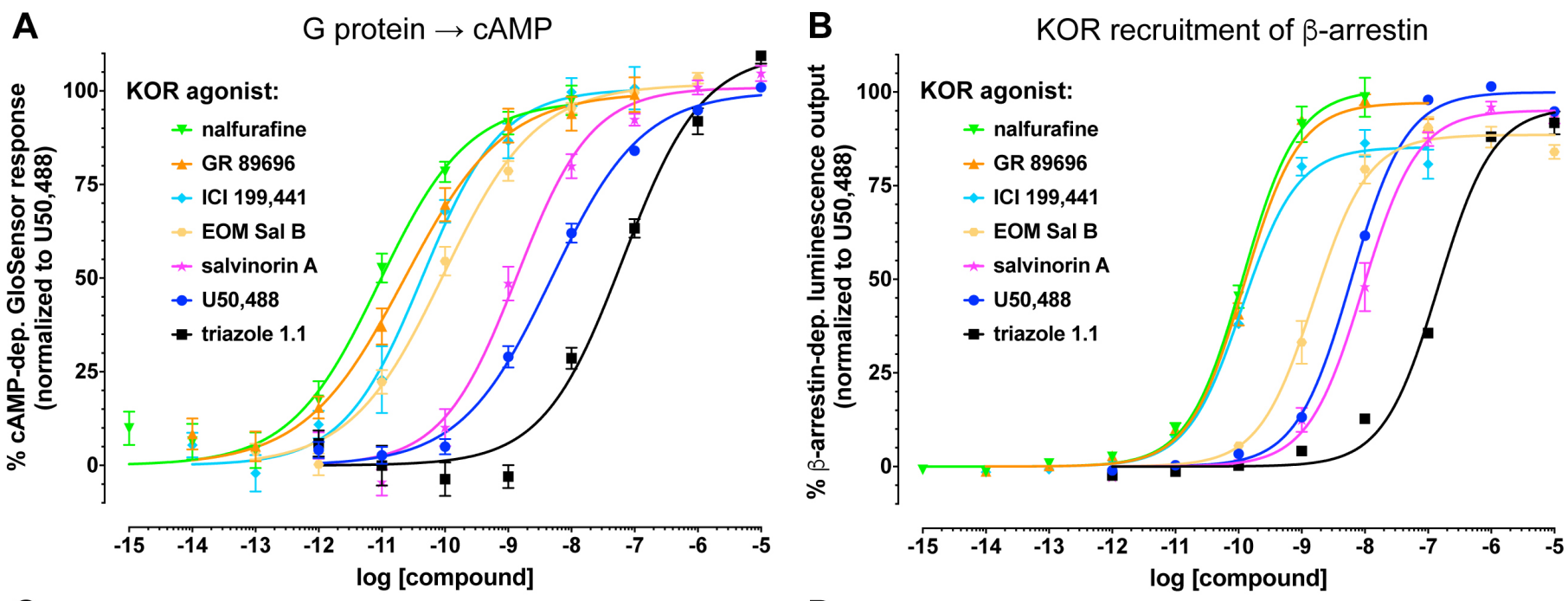

C

Bias toward G protein $\rightarrow$ cAMP

KOR agonist bias factor $-95 \% \mathrm{Cl} \quad+95 \% \mathrm{Cl}$

$\begin{array}{cccc}\text { U50,488 } & 1 & & \\ \text { triazole 1.1 } & 1.99 & 1.01 & 3.90 \\ \text { GR 89696 } & 4.21 & 2.15 & 8.27 \\ \text { nalfurafine } & 7.73 & 3.94 & 15.16 \\ \text { salvinorin A } & 5.57 & 2.84 & 10.93 \\ \text { EOM Sal B } & 15.26 & 7.78 & 29.95 \\ \text { ICI 199,441 } & 2.25 & 1.14 & 4.41\end{array}$

D

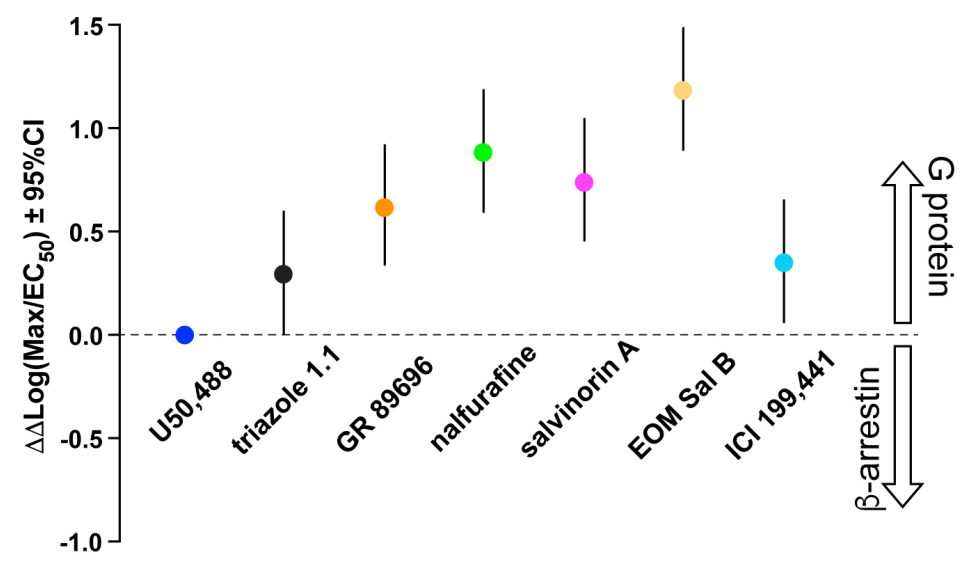

Figure 1. Nalfurafine is a potent $\mathbf{G}$ protein biased KOR agonist. Comparison of $G$ protein and $\beta$-arrestin signaling outcomes with a variety of KOR ligands (at indicated concentrations) as compared to the reference standard U50,488. (A) G protein signaling was assessed with a GloSensor assay of cyclic AMP inhibition. (B) $\beta$-arrestin recruitment to the activated KOR was assessed via the TANGO assay. (C,D) Results from GloSensor and TANGO assays used to calculate Bias Factors for each compound from observed maximal efficacy ( $\mathrm{E}_{\max }$ or "Max") and potency $\left(\mathrm{EC}_{50}\right)$ values. $\quad \log \left(\mathrm{Max}_{\mathrm{E}} \mathrm{EC}_{50}\right)$ values, with their $95 \%$ confidence intervals (CIs), are plotted in panel D for each compound to indicate relative bias towards G protein signaling. All compounds were tested in triplicate alongside the reference standard $\mathrm{U} 50,488 . \mathrm{N} \geq 3$ for all compounds. 
3.6.2 Spinal anti-nociception in C57BL/6J mice is equivalent at $5 \mathrm{mg} / \mathrm{kg} \mathrm{U} 50,488$ and 0.03 $\mathrm{mg} / \mathrm{kg}$ nalfurafine 


\section{tail immersion assay of spinal anti-nociception}

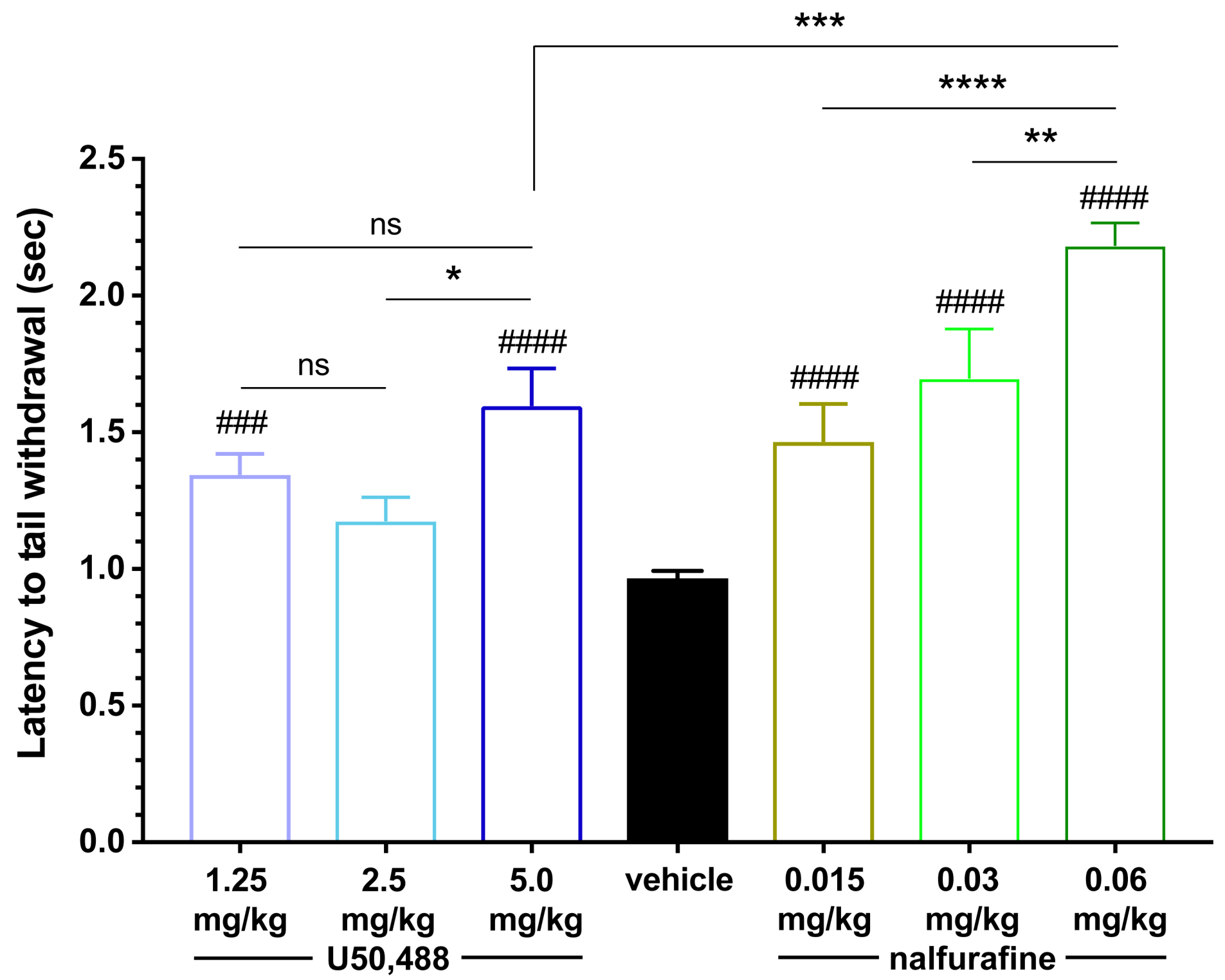

Figure 2. Spinal anti-nociception in C57BL/6J mice is equivalent at $5 \mathrm{mg} / \mathrm{kg} \mathrm{U50,488} \mathrm{and} 0.03 \mathrm{mg} / \mathrm{kg}$ nalfurafine. Mice were treated with vehicle $30 \mathrm{~min}$ prior to establishing baseline latencies, then treated with indicated doses of nalfurafine or U50,488 $30 \mathrm{~min}$ prior to testing. Data were analyzed by one- way ANOVA with Dunnett's multiple comparison post hoc test to assess for differences from the pooled vehicle. Holm-sidak multiple comparison post hoc test was used to assess for differences between treatment groups $\left(\mathrm{n}=10-18\right.$ for all treatment conditions; $\mathrm{ns}$, non-significant; ${ }^{*}, p<0.05 ; * *, p<0.01 ; * * * *$, $p<0.0001 ; \# \# \#, p<0.001 ; \# \# \# \#, p<0.0001$.) 
3.6.3 Nalfurafine potentiates morphine-induced supraspinal analgesia in C57BL/6J mice 

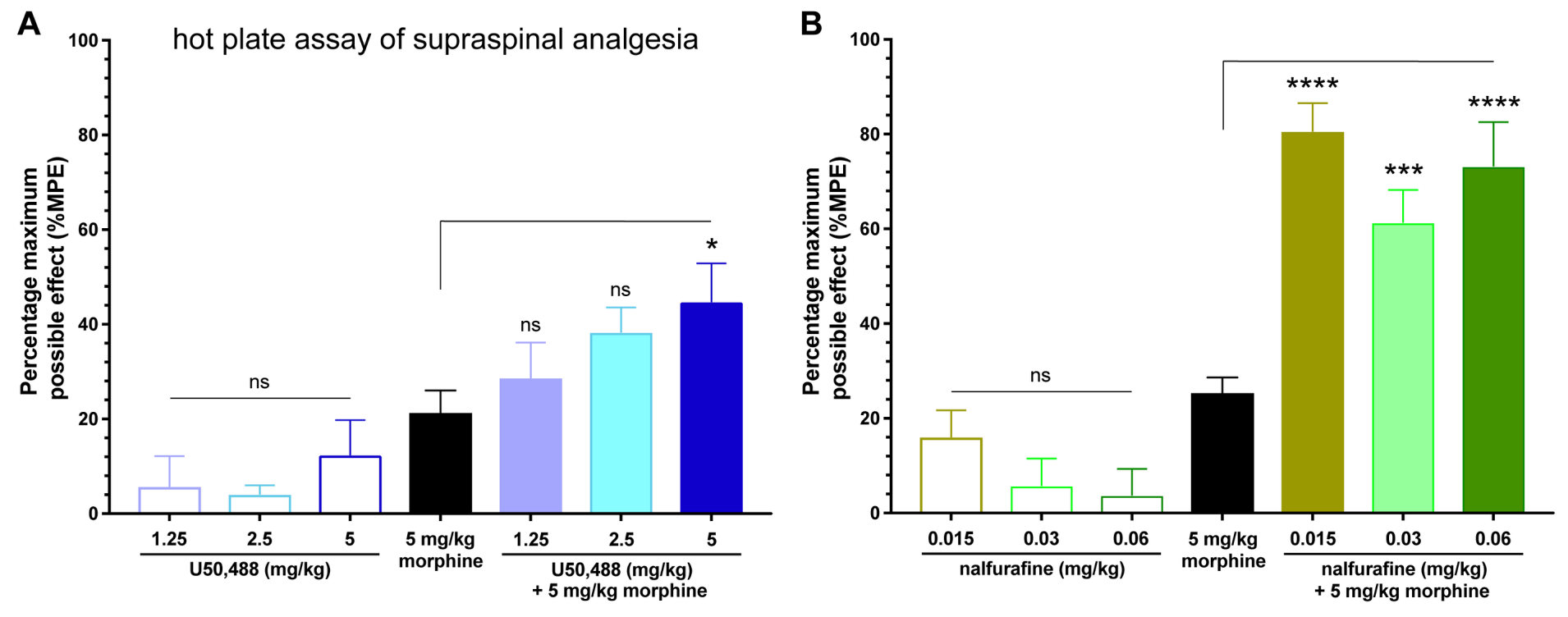

Figure 3. Nalfurafine potentiates morphine-induced supraspinal analgesia in C57BL/6J mice. Mice were treated with indicated doses of morphine, nalfurafine, U50,488, or a combination of morphine $(5$ $\mathrm{mg} / \mathrm{kg}$ ) with either nalfurafine or U50,488. Latency to nociceptive response was recorded and compared to the response to saline $[\% \mathrm{MPE}=($ test response - baseline $) /(30 \mathrm{sec}-$ baseline $) ;$ thus, $100 \% \mathrm{MPE}=30 \mathrm{sec}$ with no sign of nociception]. Data were analyzed by one- way ANOVA with Dunnett' multiple comparison post hoc test to assess differences from $5 \mathrm{mg} / \mathrm{kg}$ Morphine and Holm-sidak multiple comparison post hoc test to assess differences between treatment groups. ns, non-significant; ${ }^{*}, p<0.05$;

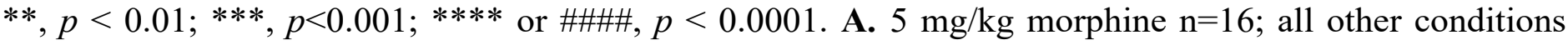
$\mathrm{n}=7-9$. B. $5 \mathrm{mg} / \mathrm{kg}$ morphine $\mathrm{n}=17$; all other conditions $\mathrm{n}=8-13$. 

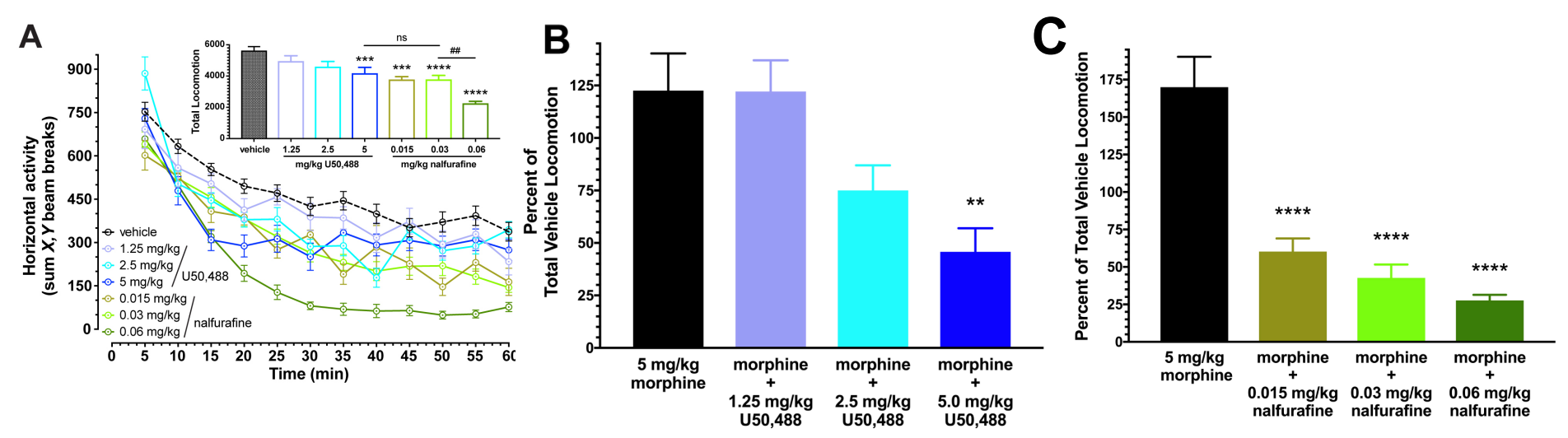

Figure 4. Nalfurafine treatment suppresses both spontaneous and morphine-induced locomotion. Assessment of open field locomotion elicited by environmental novelty or morphine administration. (A) For assessment of spontaneous locomotion, mice were administered vehicle or indicated single drug and immediately placed into the open field chamber for $60 \mathrm{~min}$. (B, C) For assessment of morphine-induced locomotion, mice were again habituated to the chamber for $30 \mathrm{~min}$ (on Day 3) before receiving $5 \mathrm{mg} / \mathrm{kg}$ morphine with vehicle, or $5 \mathrm{mg} / \mathrm{kg}$ morphine with either $1.25,2.5$ or $5 \mathrm{mg} / \mathrm{kg} \mathrm{U} 50,488$ (panel B), or $5 \mathrm{mg} / \mathrm{kg}$ morphine with either $0.015,0.03$ or $0.06 \mathrm{mg} / \mathrm{kg}$ nalfurafine (panel C) and assessed for locomotor behavior for an additional $60 \mathrm{~min}$. Locomotion was measured by number of IR-beam breaks per $1 \mathrm{~min}$. Data are presented as percent of pooled vehicle locomotion over the $60 \mathrm{~min}$ post injection for suppression of novelty induced locomotion. Total locomotion data were analyzed by one-way ANOVA with a Dunnett's post hoc analysis to compare treatment groups to the vehicle alone or vehicle + morphine condition and Tukey's post hoc analysis to assess difference between treatment conditions for novelty locomotion. Novelty locomotion n: vehicle $=41$, all other conditions 7-16. Morphine suppressed locomotion $\mathrm{n}=7-11$ for all conditions. ${ }^{*}, \mathrm{p}<0.05 ; * *, \mathrm{p}<0.01 ; * * *$, $\mathrm{p}<0.001 ; * * * *, \mathrm{p}<0.0001 . \# \#, \mathrm{p}<0.01 ; \#, \mathrm{p}<0.05$

3.6.5 Nalfurafine produces conditioned place aversion (CPA) in C57BL/6J mice at doses that do not reduce morphine CPP 

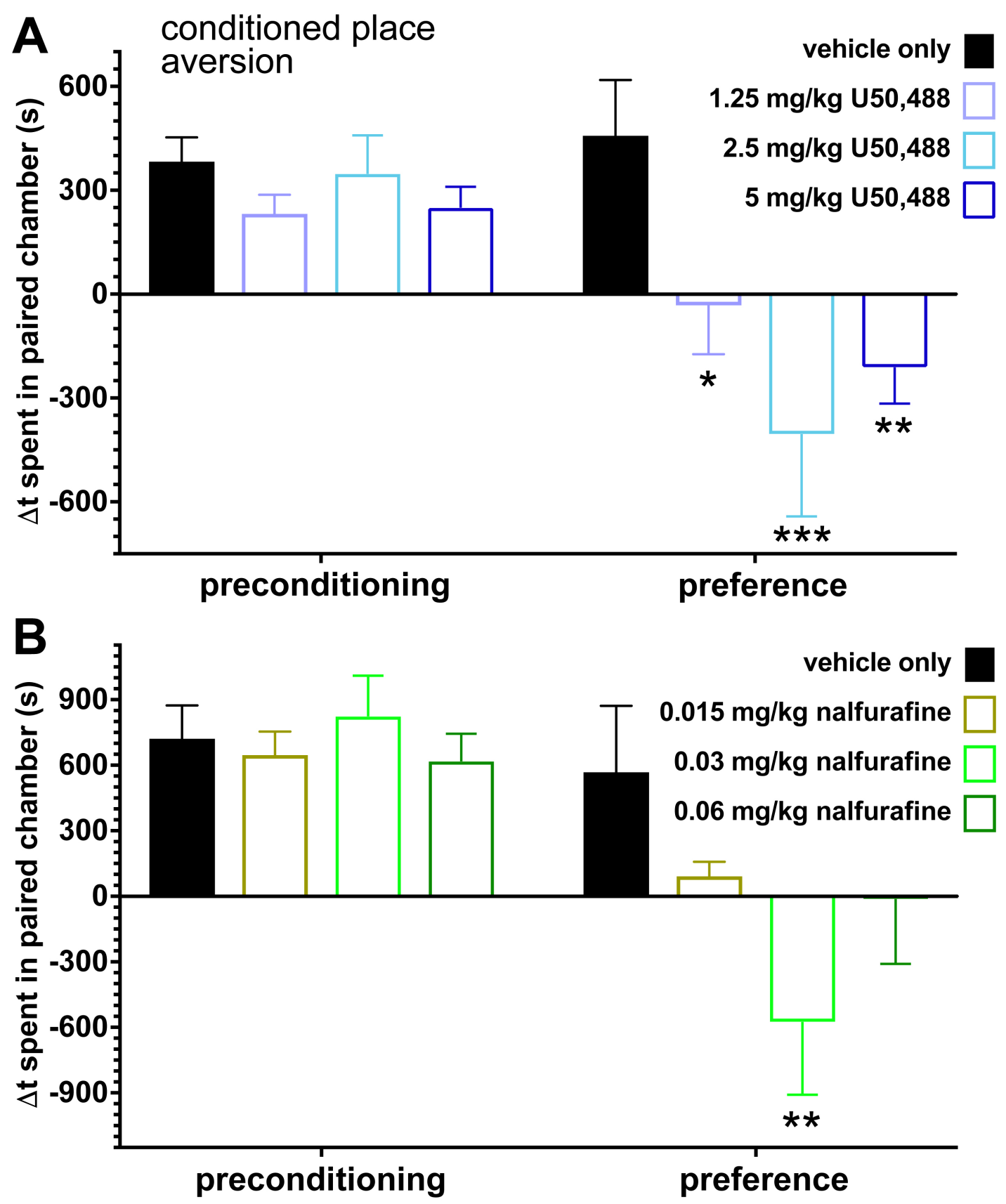

Figure 5. Nalfurafine produces conditioned place aversion (CPA) in C57BL/6J mice at doses that do not reduce morphine CPP. Mice were acclimated to the two-chambered apparatus and allowed to display a side preference. Then, mice were treated with saline (in their non-preferred chamber) or drug (in their preferred chamber) and confined to that chamber. Vehicle and drug were given on alternate days for four days. On test day, the mice were allowed free access to either chamber. The preference for the drug-paired chamber was measured as the time spent in the drug-paired chamber minus the time spent in the vehicle-paired chamber. (A) 
Mice treated with U50,488 displayed a significantly reduced preference for the drug-paired chamber $(* *, p<$ 0.01; ***, $\left.\mathrm{p}<0.0001,{ }^{* * *}, \mathrm{p}<0.0004\right)$. Vehicle, $\mathrm{n}=8 ; 1.25 \mathrm{mg} / \mathrm{kg}, \mathrm{n}=15 ; 2.5 \mathrm{mg} / \mathrm{kg} \mathrm{U} 50, \mathrm{n}=9 ; 5 \mathrm{mg} / \mathrm{kg} \mathrm{U} 50,488$, $\mathrm{n}=11$. (B) Mice treated with $0.03 \mathrm{mg} / \mathrm{kg}$ nalfurafine, but not 0.015 or $0.06 \mathrm{mg} / \mathrm{kg}$ nalfurafine, displayed reduced preference for the drug-paired chamber. Vehicle, $\mathrm{n}=20 ; 0.015 \mathrm{mg} / \mathrm{kg}, \mathrm{n}=8 ; 0.03 \mathrm{mg} / \mathrm{kg}$ nalfurafine, $\mathrm{n}=12 ; 0.06$ $\mathrm{mg} / \mathrm{kg}$ nalfurafine $\mathrm{n}=14$. Data were analyzed by one-way ANOVA with a Dunnett's multiple comparisons test comparing to vehicle $(*)$ or a Holm-Sidak test to compare between doses of U50,488 or nalfurafine. ${ }^{* *}, p<$ $0.01 ; * * *, \mathrm{p}<0.001 ; * * * *, \mathrm{p}<0.0001$.

3.6.6 Nalfurafine, like the conventional KOR agonist U50,488, reduces morphine-induced conditioned place preference (CPP) in $\mathrm{C} 57 \mathrm{BL} / 6 \mathrm{~J}$ mice 

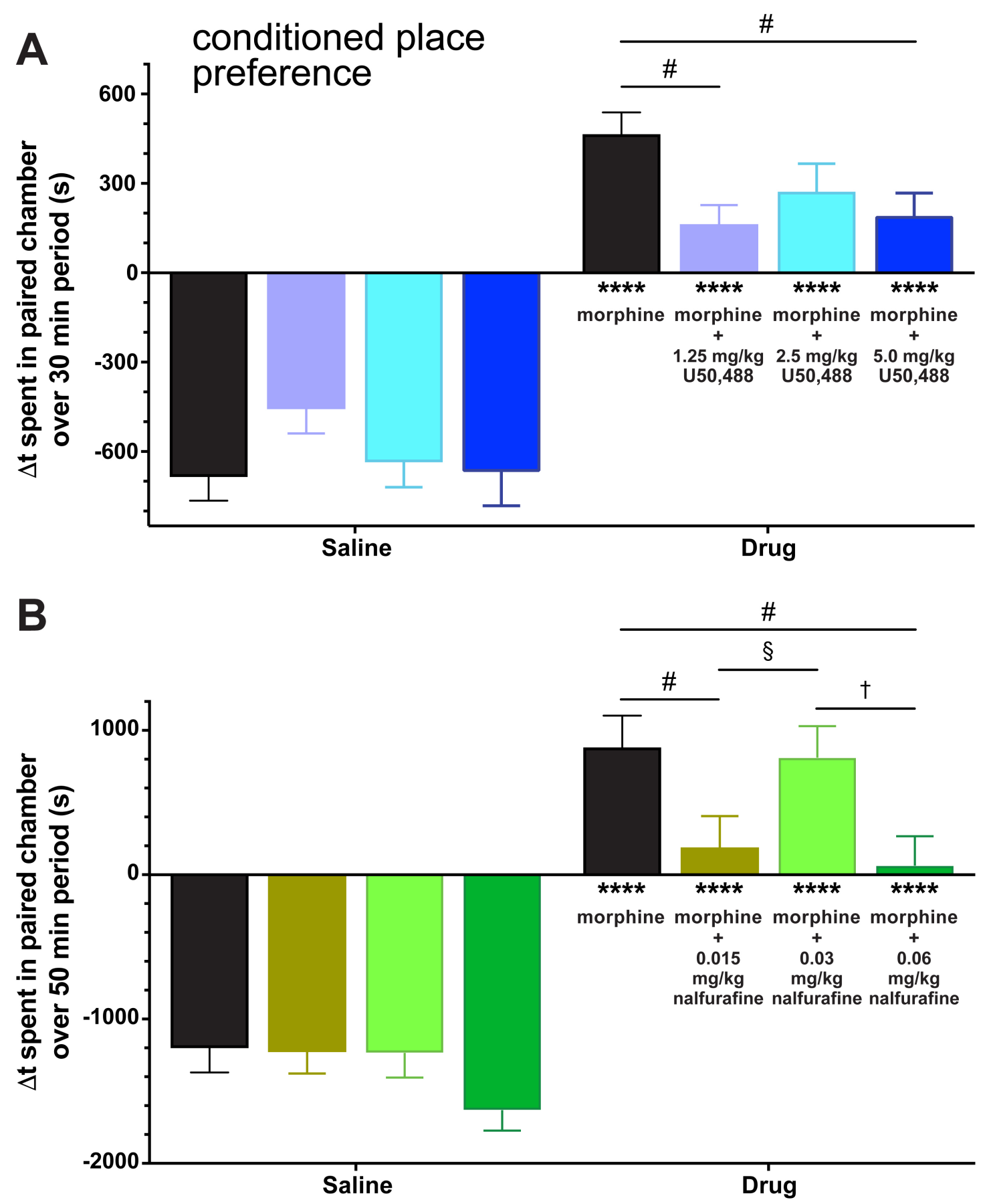

Figure 6. Nalfurafine, like the conventional KOR agonist U50,488, reduces morphine-induced conditioned place preference $(\mathrm{CPP})$ in $\mathbf{C 5 7 B L} / 6 \mathrm{~J}$ mice. Mice were acclimated to the two-chambered apparatus and allowed to display a side preference. Then, mice were treated with vehicle (in their preferred chamber) or drug (in their non-preferred chamber) and confined to that chamber for 30 or $50 \mathrm{~min}$ (for U50,488 or nalfurafine, respectively). Vehicle or morphine was given on alternate days for four days. On test day, the 
mice were allowed free access to both chambers. The preference for the drug-paired chamber was measured as the time spent in the drug-paired chamber minus the time spent in the vehicle-paired chamber. (A) Mice coadministered morphine $(5 \mathrm{mg} / \mathrm{kg})$ and U50,488 (1.25 or $5 \mathrm{mg} / \mathrm{kg})$ displayed reduced preference for the drugpaired chamber. Morphine alone (+ vehicle), $\mathrm{n}=25$; Morphine plus U50,488, $\mathrm{n}=18-21$. (B) Mice coadministered morphine $(5 \mathrm{mg} / \mathrm{kg})$ and nalfurafine $(0.015$ or $0.06 \mathrm{mg} / \mathrm{kg})$ displayed reduced preference for the drug-paired chamber. Morphine alone ( + vehicle), $n=23$; Morphine plus nalfurafine, $n=18-26$. Data were analyzed by two-way ANOVA with a Sidak's multiple comparisons test comparing to preconditioning (*), a Dunnett's test comparing to morphine alone (\#), or a Holm-Sidak test to compare between doses of U50,488 or nalfurafine co-administration (††). \#, $p<0.05 ; \dagger \uparrow, p<0.01 ; * * * *, p<0.0001$.

\section{7 - References}


Abraham AD, Schattauer SS, Reichard KL, Cohen JH, Fontaine HM, Song AJ, Johnson SD, Land BB and Chavkin C (2018) Estrogen Regulation of GRK2 Inactivates Kappa Opioid Receptor Signaling Mediating Analgesia, But Not Aversion. J Neurosci 38:8031-8043.

Allen JA, Yost JM, Setola V, Chen X, Sassano MF, Chen M, Peterson S, Yadav PN, Huang XP, Feng B, Jensen NH, Che X, Bai X, Frye SV, Wetsel WC, Caron MG, Javitch JA, Roth BL and Jin J (2011) Discovery of beta-arrestin-biased dopamine D2 ligands for probing signal transduction pathways essential for antipsychotic efficacy. Proc Natl Acad Sci U S A 108:18488-18493.

Bardo MT, Bowling SL and Pierce RC (1990) Changes in locomotion and dopamine neurotransmission following amphetamine, haloperidol, and exposure to novel environmental stimuli. Psychopharmacology (Berl) 101:338-343.

Barnea G, Strapps W, Herrada G, Berman Y, Ong J, Kloss B, Axel R and Lee KJ (2008) The genetic design of signaling cascades to record receptor activation. Proc Natl Acad Sci U S A 105:64-69.

Berg KA, Rowan MP, Sanchez TA, Silva M, Patwardhan AM, Milam SB, Hargreaves KM and Clarke WP (2011) Regulation of kappa-opioid receptor signaling in peripheral sensory neurons in vitro and in vivo. J Pharmacol Exp Ther 338:92-99.

Bohn LM and Aube J (2017) Seeking (and Finding) Biased Ligands of the Kappa Opioid Receptor. ACS Med Chem Lett 8:694-700.

Briggs SL and Rech RH (2009) Antinociceptive interactions of micro- and kappa-opioid agonists in the colorectal distension assay in rats. Pharmacol Biochem Behav 92:343-350.

Bromberg-Martin ES, Matsumoto M and Hikosaka O (2010) Dopamine in motivational control: rewarding, aversive, and alerting. Neuron 68:815-834.

Bruchas MR, Land BB, Aita M, Xu M, Barot SK, Li S and Chavkin C (2007) Stress-induced p38 mitogenactivated protein kinase activation mediates kappa-opioid-dependent dysphoria. J Neurosci 27:1161411623. 
Bruchas MR, Land BB, Lemos JC and Chavkin C (2009) CRF1-R activation of the dynorphin/kappa opioid system in the mouse basolateral amygdala mediates anxiety-like behavior. PLoS One 4:e8528.

Bruijnzeel AW (2009) kappa-Opioid receptor signaling and brain reward function. Brain Res Rev 62:127-146.

Brust TF, Morgenweck J, Kim SA, Rose JH, Locke JL, Schmid CL, Zhou L, Stahl EL, Cameron MD, Scarry SM, Aube J, Jones SR, Martin TJ and Bohn LM (2016) Biased agonists of the kappa opioid receptor suppress pain and itch without causing sedation or dysphoria. Sci Signal 9:ra117.

Carey AN, Lyons AM, Shay CF, Dunton O and McLaughlin JP (2009) Endogenous kappa opioid activation mediates stress-induced deficits in learning and memory. J Neurosci 29:4293-4300.

Carlezon WA, Jr., Beguin C, DiNieri JA, Baumann MH, Richards MR, Todtenkopf MS, Rothman RB, Ma Z, Lee DY and Cohen BM (2006) Depressive-like effects of the kappa-opioid receptor agonist salvinorin A on behavior and neurochemistry in rats. J Pharmacol Exp Ther 316:440-447.

Castellano C, Ammassari-Teule M, Libri V and Pavone F (1988) Effects of kappa-opioid receptor agonists on locomotor activity and memory processes in mice. Pol J Pharmacol Pharm 40:507-513.

Chavkin C (2011) The therapeutic potential of kappa-opioids for treatment of pain and addiction. Neuropsychopharmacology 36:369-370.

Chavkin C, Schattauer SS and Levin JR (2014) Arrestin-mediated activation of p38 MAPK: molecular mechanisms and behavioral consequences. Handb Exp Pharmacol 219:281-292.

Chefer VI, Czyzyk T, Bolan EA, Moron J, Pintar JE and Shippenberg TS (2005) Endogenous kappa-opioid receptor systems regulate mesoaccumbal dopamine dynamics and vulnerability to cocaine. $J$ Neurosci 25:5029-5037.

Ehrich JM, Messinger DI, Knakal CR, Kuhar JR, Schattauer SS, Bruchas MR, Zweifel LS, Kieffer BL, Phillips PE and Chavkin C (2015a) Kappa Opioid Receptor-Induced Aversion Requires p38 MAPK Activation in VTA Dopamine Neurons. J Neurosci 35:12917-12931.

Ehrich JM, Messinger DI, Knakal CR, Kuhar JR, Schattauer SS, Bruchas MR, Zweifel LS, Kieffer BL, Phillips PEM and Chavkin C (2015b) Kappa Opioid Receptor-Induced Aversion Requires p38 MAPK 
Activation in VTA Dopamine Neurons. The Journal of neuroscience : the official journal of the Society for Neuroscience 35:12917-12931.

Endoh T, Matsuura H, Tajima A, Izumimoto N, Tajima C, Suzuki T, Saitoh A, Suzuki T, Narita M, Tseng L and Nagase H (1999) Potent antinociceptive effects of TRK-820, a novel kappa-opioid receptor agonist. Life Sci 65:1685-1694.

Ewald AWM, Bosch PJ, Culverhouse A, Crowley RS, Neuenswander B, Prisinzano TE and Kivell BM (2017) The C-2 derivatives of salvinorin A, ethoxymethyl ether Sal B and beta-tetrahydropyran Sal B, have anti-cocaine properties with minimal side effects. Psychopharmacology (Berl) 234:2499-2514.

Fields HL and Margolis EB (2015) Understanding opioid reward. Trends Neurosci 38:217-225.

Greenwald MK and Stitzer ML (1998) Butorphanol agonist effects and acute physical dependence in opioid abusers: comparison with morphine. Drug Alcohol Depend 53:17-30.

Gross JD, Kaski SW, Schroer AB, Wix KA, Siderovski DP and Setola V (2018) Regulator of G protein signaling-12 modulates the dopamine transporter in ventral striatum and locomotor responses to psychostimulants. J Psychopharmacol 32:191-203.

He L and Lee NM (1997) DynorphinA-(2-17) restores spinal/supraspinal morphine synergy in morphinetolerant mice. J Pharmacol Exp Ther 280:1210-1214.

Hernandez A, Soto-Moyano R, Mestre C, Eschalier A, Pelissier T, Paeile C and Contreras E (1995) Intrathecal pertussis toxin but not cyclic AMP blocks kappa opioid-induced antinociception in rat. Int J Neurosci 81:193-197.

Inui S (2015) Nalfurafine hydrochloride to treat pruritus: a review. Clin Cosmet Investig Dermatol 8:249-255. Jasinski DR and Mansky PA (1972) Evaluation of nalbuphine for abuse potential. Clin Pharmacol Ther 13:7890.

Jensen TS (1997) Opioids in the brain: supraspinal mechanisms in pain control. Acta Anaesthesiol Scand 41:123-132. 
Johnson MW, MacLean KA, Caspers MJ, Prisinzano TE and Griffiths RR (2016) Time course of pharmacokinetic and hormonal effects of inhaled high-dose salvinorin A in humans. J Psychopharmacol 30:323-329.

Jones CM (2013) Heroin use and heroin use risk behaviors among nonmedical users of prescription opioid pain relievers - United States, 2002-2004 and 2008-2010. Drug Alcohol Depend 132:95-100.

Jordan M, Schallhorn A and Wurm FM (1996) Transfecting mammalian cells: optimization of critical parameters affecting calcium-phosphate precipitate formation. Nucleic Acids Res 24:596-601.

Kanjhan R (1995) Opioids and pain. Clin Exp Pharmacol Physiol 22:397-403.

Kenakin T (2017) A Scale of Agonism and Allosteric Modulation for Assessment of Selectivity, Bias, and Receptor Mutation. Mol Pharmacol 92:414-424.

Khotib J, Narita M, Suzuki M, Yajima Y and Suzuki T (2004) Functional interaction among opioid receptor types: up-regulation of mu- and delta-opioid receptor functions after repeated stimulation of kappaopioid receptors. Neuropharmacology 46:531-540.

Koh H (2015) Community Approaches to the Opioid Crisis. JAMA 314:1437-1438.

Koo JW, Mazei-Robison MS, Chaudhury D, Juarez B, LaPlant Q, Ferguson D, Feng J, Sun H, Scobie KN, Damez-Werno D, Crumiller M, Ohnishi YN, Ohnishi YH, Mouzon E, Dietz DM, Lobo MK, Neve RL, Russo SJ, Han MH and Nestler EJ (2012) BDNF is a negative modulator of morphine action. Science 338: $124-128$.

Kozono H, Yoshitani H and Nakano R (2018) Post-marketing surveillance study of the safety and efficacy of nalfurafine hydrochloride (Remitch $((\mathrm{R}))$ capsules $2.5 \mathrm{mug})$ in 3,762 hemodialysis patients with intractable pruritus. Int J Nephrol Renovasc Dis 11:9-24.

Kumor KM, Haertzen CA, Johnson RE, Kocher T and Jasinski D (1986) Human psychopharmacology of ketocyclazocine as compared with cyclazocine, morphine and placebo. J Pharmacol Exp Ther 238:960968. 
Kunihara M, Ohyama M and Nakano M (1993) Effects of spiradoline mesylate, a selective kappa-opioidreceptor agonist, on the central dopamine system with relation to mouse locomotor activity and analgesia. Jpn J Pharmacol 62:223-230.

Kuzmin AV, Semenova S, Gerrits MA, Zvartau EE and Van Ree JM (1997) Kappa-opioid receptor agonist U50,488H modulates cocaine and morphine self-administration in drug-naive rats and mice. Eur $J$ Pharmacol 321:265-271.

Laman-Maharg AR, Copeland T, Sanchez EO, Campi KL and Trainor BC (2017) The long-term effects of stress and kappa opioid receptor activation on conditioned place aversion in male and female California mice. Behav Brain Res 332:299-307.

Land BB, Bruchas MR, Schattauer S, Giardino WJ, Aita M, Messinger D, Hnasko TS, Palmiter RD and Chavkin C (2009) Activation of the kappa opioid receptor in the dorsal raphe nucleus mediates the aversive effects of stress and reinstates drug seeking. 106:19168-19173.

Lindholm S, Werme M, Brene S and Franck J (2001) The selective kappa-opioid receptor agonist U50,488H attenuates voluntary ethanol intake in the rat. Behav Brain Res 120:137-146.

Liu JJ, Chiu YT, DiMattio KM, Chen C, Huang P, Gentile TA, Muschamp JW, Cowan A, Mann M and LiuChen LY (2018) Phosphoproteomic approach for agonist-specific signaling in mouse brains: mTOR pathway is involved in kappa opioid aversion. Neuropsychopharmacology.

MacLean KA, Johnson MW, Reissig CJ, Prisinzano TE and Griffiths RR (2013) Dose-related effects of salvinorin A in humans: dissociative, hallucinogenic, and memory effects. Psychopharmacology (Berl) 226:381-392.

Manchikanti L, Helm S, 2nd, Fellows B, Janata JW, Pampati V, Grider JS and Boswell MV (2012) Opioid epidemic in the United States. Pain Physician 15:ES9-38.

Maqueda AE, Valle M, Addy PH, Antonijoan RM, Puntes M, Coimbra J, Ballester MR, Garrido M, Gonzalez M, Claramunt J, Barker S, Johnson MW, Griffiths RR and Riba J (2015) Salvinorin-A Induces Intense 
Dissociative Effects, Blocking External Sensory Perception and Modulating Interoception and Sense of Body Ownership in Humans. Int J Neuropsychopharmacol 18.

Masahiko F, Tsutomu S, Minoru N, Miwa M and Hiroshi N (1993) Blockade of morphine reward through the activation of $\kappa$-opioid receptors in mice. Neuropharmacology 32:1315-1323.

McLaughlin JP, Land BB, Li S, Pintar JE and Chavkin C (2006) Prior activation of kappa opioid receptors by U50,488 mimics repeated forced swim stress to potentiate cocaine place preference conditioning. Neuropsychopharmacology 31:787-794.

Miaskowski C, Sutters KA, Taiwo YO and Levine JD (1992) Antinociceptive and motor effects of delta/mu and kappa/mu combinations of intrathecal opioid agonists. PAIN 49:137-144.

Miaskowski C, Taiwo YO and Levine JD (1993) Antinociception produced by receptor selective opioids. Modulation of supraspinal antinociceptive effects by spinal opioids. Brain Research 608:87-94.

Morani AS, Kivell B, Prisinzano TE and Schenk S (2009a) Effect of kappa-opioid receptor agonists U69593, $\mathrm{U} 50488 \mathrm{H}$, spiradoline and salvinorin A on cocaine-induced drug-seeking in rats. Pharmacol Biochem Behav 94:244-249.

Morani AS, Kivell B, Prisinzano TE and Schenk S (2009b) Effect of kappa-opioid receptor agonists U69593, U50488H, spiradoline and salvinorin A on cocaine-induced drug-seeking in rats. Pharmacology, biochemistry, and behavior 94:244-249.

Mouri A, Koseki T, Narusawa S, Niwa M, Mamiya T, Kano S, Sawa A and Nabeshima T (2012) Mouse strain differences in phencyclidine-induced behavioural changes. Int J Neuropsychopharmacol 15:767-779.

Mueller D, Perdikaris D and Stewart J (2002) Persistence and drug-induced reinstatement of a morphineinduced conditioned place preference. Behavioural Brain Research 136:389-397.

Muschamp JW, Nemeth CL, Robison AJ, Nestler EJ and Carlezon WA, Jr. (2012) DeltaFosB enhances the rewarding effects of cocaine while reducing the pro-depressive effects of the kappa-opioid receptor agonist U50488. Biol Psychiatry 71:44-50. 
Napier TC, Herrold AA and De Wit H (2013) Using conditioned place preference to identify relapse prevention medications. Neuroscience \& Biobehavioral Reviews 37:2081-2086.

Narita M, Takahashi Y, Takamori K, Funada M, Suzuki T, Misawa M and Nagase H (1993) Effects of kappaagonist on the antinociception and locomotor enhancing action induced by morphine in mice. Jpn J Pharmacol 62:15-24.

Negus SS, Schrode K and Stevenson GW (2008) Micro/kappa opioid interactions in rhesus monkeys: implications for analgesia and abuse liability. Exp Clin Psychopharmacol 16:386-399.

Preston KL and Bigelow GE (1993) Differential naltrexone antagonism of hydromorphone and pentazocine effects in human volunteers. J Pharmacol Exp Ther 264:813-823.

Preston KL, Bigelow GE, Bickel WK and Liebson IA (1989) Drug discrimination in human postaddicts: agonist-antagonist opioids. J Pharmacol Exp Ther 250:184-196.

Preston KL, Bigelow GE and Liebson IA (1987) Comparative evaluation of morphine, pentazocine and ciramadol in postaddicts. J Pharmacol Exp Ther 240:900-910.

Rada PV, Mark GP, Taylor KM and Hoebel BG (1996) Morphine and naloxone, i.p. or locally, affect extracellular acetylcholine in the accumbens and prefrontal cortex. Pharmacol Biochem Behav 53:809816.

Raehal KM and Bohn LM (2011) The role of beta-arrestin2 in the severity of antinociceptive tolerance and physical dependence induced by different opioid pain therapeutics. Neuropharmacology 60:58-65.

Rankovic Z, Brust TF and Bohn LM (2016) Biased agonism: An emerging paradigm in GPCR drug discovery. Bioorg Med Chem Lett 26:241-250.

Redila VA and Chavkin C (2008) Stress-induced reinstatement of cocaine seeking is mediated by the kappa opioid system. Psychopharmacology (Berl) 200:59-70.

Ren MF, Lu CH and Han JS (1985) Dynorphin-A-(1-13) antagonizes morphine analgesia in the brain and potentiates morphine analgesia in the spinal cord. Peptides 6:1015-1020. 
Robinson SA, Erickson RL, Browne CA and Lucki I (2017) A role for the mu opioid receptor in the antidepressant effects of buprenorphine. Behav Brain Res 319:96-103.

Robles CF, McMackin MZ, Campi KL, Doig IE, Takahashi EY, Pride MC and Trainor BC (2014) Effects of kappa opioid receptors on conditioned place aversion and social interaction in males and females. Behav Brain Res 262:84-93.

Schattauer SS, Kuhar JR, Song A and Chavkin C (2017) Nalfurafine is a G-protein biased agonist having significantly greater bias at the human than rodent form of the kappa opioid receptor. Cell Signal 32:5965.

Sellings LH and Clarke PB (2003) Segregation of amphetamine reward and locomotor stimulation between nucleus accumbens medial shell and core. J Neurosci 23:6295-6303.

Siebert DJ (1994) Salvia divinorum and salvinorin A: new pharmacologic findings. J Ethnopharmacol 43:5356.

Sutters KA, Miaskowski C, Taiwo YO and Levine JD (1990) Analgesic synergy and improved motor function produced by combinations of mu-delta- and mu-kappa-opioids. Brain Res 530:290-294.

Suzuki T, Shiozaki Y, Masukawa Y, Misawa M and Nagase H (1992) The Role of Mu- and Kappa-Opioid Receptors in Cocaine-Induced Conditioned Place Preference. The Japanese Journal of Pharmacology 58:435-442.

Tao PL, Liang KW, Sung WY, Wu YT and Huang EY (2006) Nalbuphine is effective in decreasing the rewarding effect induced by morphine in rats. Drug Alcohol Depend 84:175-181.

Townsend EA, Naylor JE, Negus SS, Edwards SR, Qureshi HN, McLendon HW, McCurdy CR, Kapanda CN, do Carmo JM, da Silva FS, Hall JE, Sufka KJ and Freeman KB (2017a) Effects of nalfurafine on the reinforcing, thermal antinociceptive, and respiratory-depressant effects of oxycodone: modeling an abuse-deterrent opioid analgesic in rats. Psychopharmacology (Berl):10.1007/s00213-00017-0465200213. 
Townsend EA, Naylor JE, Negus SS, Edwards SR, Qureshi HN, McLendon HW, McCurdy CR, Kapanda CN, do Carmo JM, da Silva FS, Hall JE, Sufka KJ and Freeman KB (2017b) Effects of nalfurafine on the reinforcing, thermal antinociceptive, and respiratory-depressant effects of oxycodone: modeling an abuse-deterrent opioid analgesic in rats. Psychopharmacology (Berl) 234:2597-2605.

Tsuji M, Takeda H, Matsumiya T, Nagase H, Narita M and Suzuki T (2001) The novel kappa-opioid receptor agonist TRK-820 suppresses the rewarding and locomotor-enhancing effects of morphine in mice. Life Sci 68:1717-1725.

Ueno Y, Mori A and Yanagita T (2013) One year long-term study on abuse liability of nalfurafine in hemodialysis patients. Int J Clin Pharmacol Ther 51:823-831.

Urban JD, Clarke WP, von Zastrow M, Nichols DE, Kobilka B, Weinstein H, Javitch JA, Roth BL, Christopoulos A, Sexton PM, Miller KJ, Spedding M and Mailman RB (2007) Functional selectivity and classical concepts of quantitative pharmacology. J Pharmacol Exp Ther 320:1-13.

Verborgh CM, Camu F and Meert TF (1997) Interaction between sufentanil and U-50488H with respect to antinociception and respiratory depression in rats. Acta Anaesthesiol Scand 41:895-902.

Volkow ND and Collins FS (2017) The Role of Science in Addressing the Opioid Crisis. N Engl J Med.

Walsh SL and Babalonis S (2017) The Abuse Potential of Prescription Opioids in Humans-Closing in on the First Century of Research. Curr Top Behav Neurosci 34:33-58.

Walsh SL, Chausmer AE, Strain EC and Bigelow GE (2008) Evaluation of the mu and kappa opioid actions of butorphanol in humans through differential naltrexone blockade. Psychopharmacology (Berl) 196:143155.

White KL, Robinson JE, Zhu H, DiBerto JF, Polepally PR, Zjawiony JK, Nichols DE, Malanga CJ and Roth BL (2015) The G protein-biased kappa-opioid receptor agonist RB-64 is analgesic with a unique spectrum of activities in vivo. J Pharmacol Exp Ther 352:98-109. 
Zacny JP, Lichtor JL, Thapar P, Coalson DW, Flemming D and Thompson WK (1994) Comparing the subjective, psychomotor and physiological effects of intravenous butorphanol and morphine in healthy volunteers. J Pharmacol Exp Ther 270:579-588.

Zhou L, Lovell KM, Frankowski KJ, Slauson SR, Phillips AM, Streicher JM, Stahl E, Schmid CL, Hodder P, Madoux F, Cameron MD, Prisinzano TE, Aube J and Bohn LM (2013) Development of functionally selective, small molecule agonists at kappa opioid receptors. J Biol Chem 288:36703-36716.

Chapter Four

CONCLUSIONS AND FUTURE DIRECTIONS

\section{1 - SNPs identified in a West Virginian population of patients with OUD}

\subsection{1 - Significant Results}

Our analysis of a local cohort of patients in treatment for OUD identified several SNPs, out of the fourteen tested, with significantly different minor allele frequencies (MAFs) from the reference population. Of particular interest to the Siderovski lab is the finding that the rs4606 SNP within RGS2 displayed increased prevalence of the minor allele in the test population, given Dr. Siderovski's role in the first cloning of the human RGS2 cDNA in the 1990s (Siderovski et al., 1990; Siderovski et al., 1994; Wu et al., 1995) and first reporting the anxiety phenotype of mice lacking Rgs2 expression (Oliveira-Dos-Santos et al., 2000). This SNP 
within RGS2 has since been associated with anxiety disorders (Smoller et al., 2008; Stein et al., 2014) and suicidality (Cui et al., 2008) in humans. Studies of reduced RGS2 expression in mice have also demonstrated increased depressive and anxiety phenotypes (Lifschytz et al., 2012). As discussed previously, stress is a motivator of drug seeking behavior in rodents and anxiety disorders are commonly associated with substance use disorder (SUD) diagnoses (Brady et al., 2013) in humans, providing a plausible rationale for the association of the identified RGS2 SNP with the WV OUD patient population.

The presence of the minor allele of the rs1799971 SNP within OPRM1, has previously been associated with increased odds for heroin addiction and decreased analgesic sensitivity (Bart et al., 2004; Tan et al., 2009). Assessment of this polymorphism in cell culture shows decreased mu opioid receptor expression yet increased affinity for ß-endorphin (Bond et al., 1998) as well as engendering increased heroin self-administration in a transgenic mouse model (Zhang et al., 2014). Interestingly, our WV OUD patient population displayed a decreased prevalence of this polymorphism compared to the control population. As our patient cohort represents a population that is not in active addiction and has begun medication assisted therapy (MAT), this finding may indicate an interaction between the rs179971 SNP of OPRM1 and the persistence of active addiction compared to the willingness to enter treatment. Comparisons of SNP frequency within a population of active users would inform this hypothesis. The Milan Puskar Health Right free clinic in Morgantown runs one of the only needle exchange programs in the state of WV. With the goal of reducing the harm related to drug use, the clinic provides clean needles and offers counseling to those in active addiction. The needle exchange could be used to gain access to a population of active heroin users from the same geographic region as those used for the genetics studies presented in this dissertation. Should the minor allele of the rs179971 SNP within OPRM1 appear with greater frequency in this population of active heroin users than those assessed receiving MAT, it may indicate an association of the minor allele with reduced severity of addiction.

\subsection{2 - Future Directions}


The foremost limitations of the present study are the low sample size and restricted patient population. Recruitment of treatment centers outside of Morgantown and including additional border states within the Appalachian region would allow for both greater statistical power and patient stratification based on ethnicity as well as medical history (e.g., first diagnosis of OUD vs. history of OUD). Considering the relationship of the kappa opioid receptor to stress (Massaly et al., 2016; Tejeda and Bonci, 2018), inclusion of KOR (OPRK1) polymorphisms could provide important insight into the interactions between these two systems. At least one study (Kumar et al., 2012) has shown that the rs16918875 polymorphism of KOR increases addiction risk when patients also express the A118G (rs1799971) SNP of OPRM1, supporting the need to assess multiple components of addiction-related circuitry when assessing addiction risk. In addition, buprenorphine, a MOR partial agonist and KOR antagonist, is commonly used in MAT for opioid addiction (Marshalek and Sullivan, 2010; Zheng et al., 2016). Polymorphisms at KOR may potentially confer variations in the efficacy of buprenorphine for this purpose, providing a possible mechanism for screening patients into high and low responder groups before beginning therapy.

\section{2 - Preclinical assessment of the G protein-biased KOR agonists}

\subsection{1 - Significant Results}

The findings of these studies support the further investigation of G protein-biased KOR agonists as dose-sparing adjuvants to traditional MOR-targeting analgesics. Nalfurafine was shown in vitro to possess significant bias towards G protein-signaling at KOR and contrary to the unbiased agonist KOR U50,488, augmented the analgesic effect of morphine in the hot plate assay. This augmentation was observed at doses of KOR agonist that produced equivalent results in the tail-immersion assay of spinal nociception. As the analgesia provided by KOR agonism in the tail immersion assay is G protein dependent (Hernandez et al., 1995; Berg et al., 2011; White et al., 2015; Abraham et al., 2018), the augmented analgesia seen in the hot plate assay when co-administering nalfurafine with morphine may be a result of decreased $\beta$-arrestin signaling emanating from KOR agonism at either spinal or supraspinal sites. 
Sedation (as measured in mice by hypolocomotion) and dysphoria (as measured in mice by conditioned place aversion) are two effects of KOR agonists that have limited their therapeutic use in humans (Kumor et al., 1986; Zacny et al., 1994; Walsh et al., 2008). While others have reported a lack of CPA to nalfurafine (Liu et al., 2018), our results demonstrate that aversion was present at $0.03 \mathrm{mg} / \mathrm{kg}$ nalfurafine, and that locomotion was reduced with all tested doses of nalfurafine when given alone or co-administered with morphine. A dose of $0.015 \mathrm{mg} / \mathrm{kg}$ nalfurafine, however, did not produce significant CPA, a result supported by previous work (Liu et al., 2018). As all doses of nalfurafine tested produced equivalent augmentation of morphine analgesia in the hot plate assay, the possibility remains that further dose optimization to avoid both the sedative and aversive effects of nalfurafine may be possible. While the unbiased KOR agonist U50,488 did not produce locomotor sedation to as great an extent as nalfurafine, all doses of U50,488 tested produced significant CPA. Taken together, these findings suggest that the sedative effects of KOR agonists occur via G protein-mediated signaling, while the aversive effects arise downstream of $\beta$-arrestin signaling. This interpretation, however, is complicated by work utilizing BARR2 knockout mice that display both locomotor sedation and aversion when treated with unbiased KOR agonists (White et al., 2015). Further work is needed to determine if these effects truly arise via $\beta$-arrestin independent mechanisms or if there is compensation via $\beta$-arrestin1 in these mice.

The effects of nalfurafine on morphine-induced CPP are notable. KOR agonists reduce CPP for a variety of drugs of abuse (Kuzmin et al., 1997; Lindholm et al., 2001; Tsuji et al., 2001; Tao et al., 2006; Morani et al., 2009a; Ewald et al., 2017a; Townsend et al., 2017a), providing the possible additional benefit of reducing addiction liability with a co-administration paradigm. While both U50,488 and nalfurafine reduced morphineinduced place preference in our studies, each KOR agonist failed to do so with the middle dose of the ranges tested; i.e., the dose of each drug that produced the greatest CPA. A reduction in place preference when coadministering the highest dose of either KOR agonist may be attributable to the induction of cognitive deficits known to occur with high doses of KOR agonists (Castellano et al., 1988; Carey et al., 2009), also potentially explaining the lack of CPA seen with the highest dose of nalfurafine. The persistence of morphine's rewarding effects, however, when co-administered with the most aversive dose of either drug is intriguing. A common 
interpretation of the anti-rewarding properties of KOR agonists is that of positive punishment (Shippenberg et al., 1998; Wee and Koob, 2010), or an addition of aversive effects rather than the diminishment of positive effects produced by the rewarding drug (negative punishment). Rats pretreated with morphine for five consecutive days display an increased place preference for morphine, an effect that is not reduced with the addition of the KOR agonist U69593 during pretreatment (Shippenberg et al., 1998). This result supports the notion that the rewarding properties of morphine and the aversive properties of U69593 function through separate circuits when co-administered, producing a reduced preference at the level of the whole organism without altering the underlying biochemical effects of each drug.

This theory, however, would predict that doses of KOR agonist producing greater dysphoria (as measured by CPA) would produce increased levels of punishment and therefore suppress morphine-induced CPP to a greater extent. Our present results indicate the opposite effect, that doses of nalfurafine and U50,488 producing the greatest aversion reduce place preference for morphine the least. In addition, the lowest dose of both drugs (that show reduced levels of aversion) successfully reduced morphine-induced CPP. If KOR agonists do indeed reduce CPP through engagement of a punishment circuit rather than inhibition of a rewarding circuit engaged by morphine, then timing and intensity of engagement of these circuits may play an integral role in the behavioral outcomes observed. Extensive manipulation of dose of both KOR agonist and morphine, as well as alterations of pretreatment intervals will be needed as an initial step in investigating the complex interaction among the affective responses to each of these drugs.

\subsection{2 - Future Directions}

The most clinically relevant issue arresting from the results of these studies centers on identifying appropriate dose combinations of nalfurafine and co-administered opioid analgesic (Ueno et al., 2013; Kozono et al., 2018; Siderovski and Setola, 2018). As nalfurafine is currently used in Japan with a low incidence of therapeutically limiting side-effects, clinical investigations into the viability of its use as a dose-sparing adjuvant face fewer hurdles than any other G protein-biased KOR agonist used in pre-clinical studies. While our 
work supports the possibility that reduced dosing of both morphine and nalfurafine may achieve analgesia equivalent to a higher dose of morphine alone, this result needs to be confirmed experimentally by further adjusting the dose range of nalfurafine in addition to the dose range of morphine. Other nociceptive assays should be included as well to assess for therapeutic relevancy beyond thermal pain. MOR-targeting analgesics show reduced efficacy in treating inflammatory and neuropathic pain (Przewlocki and Przewlocka, 2005; McAlindon et al., 2014), while these conditions constitute the major reason for chronic out-patient opioid prescriptions (Boudreau et al., 2009; Gomes et al., 2011). An increase in the ability to manage these types of pain while reducing the likelihood of addiction would be of major therapeutic benefit to the medical community. Other therapeutically limiting effects must also be investigated, such as constipation, a side effect of MOR agonists prevalent enough to prompt the development of naloxegol (a peripherally restricted MOR antagonist) and diuresis, a side effect of KOR agonism (Leander et al., 1985; Webster, 2015). In addition, while nalfurafine was shown to reduce acetic acid-induced writhing in mice (a pain-stimulated behavior), it did not restore ICSS thresholds depressed by acetic acid administration (a pain-suppressed behavior) (Lazenka et al., 2018). Furthermore, nalfurafine alone suppressed ICSS thresholds in the absence of a painful stimulus (Lazenka et al., 2018). These results seem to indicate that nalfurafine alone does not alleviate the negative affect produced by pain, unlike traditional opioid analgesics (Altarifi et al., 2014; Porreca and Navratilova, 2017b), and nalfurafine may prevent this positive effect of traditional opioid analgesics when co-administered.

While these proposed pre-clinical and clinical studies with nalfurafine will better elucidate the viability of this drug as a dose-sparing adjuvant, additional experiments are necessary to elucidate the true relevance of $\mathrm{G}$ protein and $\beta$-arrestin signaling in producing the observed effects. Conducting parallel studies with other $G$ protein-biased KOR agonists with greater bias factors will inform this question. In addition, future studies using $B A R R 2$ knockout mice will aid in determining which effects of $\mathrm{G}$ protein-biased KOR agonists are dependent upon this particular signaling pathway, as well as if any traditionally $\beta$-arrestin-dependent effects seen with putatively G protein-biased KOR agonists (e.g., CPA to $0.03 \mathrm{mg} / \mathrm{kg}$ nalfurafine; Figure 3.6 .5 above) are simply a result of a dose range that engages the $\beta$-arrestin pathway in vivo despite the ligand possessing a demonstrable 
bias toward G protein signaling in vitro. Such studies would be greatly enhanced with the use of $\beta$-arrestin celltype and region-specific knockout mice (e.g., (Urs et al., 2016a; Zhu et al., 2017), allowing for more specific interrogation of the cell populations and neuronal circuits involved. A deeper understanding of just how MOR

and KOR produce their euphoric and dysphoric effects, respectively, will hopefully allow for the design of targeted therapeutics that alleviate pain without addiction or dysphoria.

\section{3- References}

Abraham AD, Schattauer SS, Reichard KL, Cohen JH, Fontaine HM, Song AJ, Johnson SD, Land BB and Chavkin C (2018) Estrogen Regulation of GRK2 Inactivates Kappa Opioid Receptor Signaling Mediating Analgesia, But Not Aversion. J Neurosci 38:8031-8043.

Altarifi AA, Rice KC and Negus SS (2014) Effects of -Opioid Receptor Agonists in Assays of Acute PainStimulated and Pain-Depressed Behavior in Male Rats: Role of -Agonist Efficacy and Noxious Stimulus Intensity. Journal of Pharmacology and Experimental Therapeutics 352:208-217.

Bart G, Heilig M, LaForge KS, Pollak L, Leal SM, Ott J and Kreek MJ (2004) Substantial attributable risk related to a functional mu-opioid receptor gene polymorphism in association with heroin addiction in central Sweden. Mol Psychiatry 9:547-549.

Berg KA, Rowan MP, Sanchez TA, Silva M, Patwardhan AM, Milam SB, Hargreaves KM and Clarke WP (2011) Regulation of kappa-opioid receptor signaling in peripheral sensory neurons in vitro and in vivo. J Pharmacol Exp Ther 338:92-99. 
Bond C, LaForge KS, Tian M, Melia D, Zhang S, Borg L, Gong J, Schluger J, Strong JA, Leal SM, Tischfield JA, Kreek MJ and Yu L (1998) Single-nucleotide polymorphism in the human mu opioid receptor gene alters beta-endorphin binding and activity: possible implications for opiate addiction. Proc Natl Acad Sci US A 95:9608-9613.

Boudreau D, Von Korff M, Rutter CM, Saunders K, Ray GT, Sullivan MD, Campbell CI, Merrill JO, Silverberg MJ, Banta-Green C and Weisner C (2009) Trends in long-term opioid therapy for chronic non-cancer pain. Pharmacoepidemiology and drug safety 18:1166-1175.

Brady KT, Haynes LF, Hartwell KJ and Killeen TK (2013) Substance Use Disorders and Anxiety: A Treatment Challenge for Social Workers. Social Work in Public Health 28:407-423.

Carey AN, Lyons AM, Shay CF, Dunton O and McLaughlin JP (2009) Endogenous kappa opioid activation mediates stress-induced deficits in learning and memory. J Neurosci 29:4293-4300.

Castellano C, Ammassari-Teule M, Libri V and Pavone F (1988) Effects of kappa-opioid receptor agonists on locomotor activity and memory processes in mice. Pol J Pharmacol Pharm 40:507-513.

Cui H, Nishiguchi N, Ivleva E, Yanagi M, Fukutake M, Nushida H, Ueno Y, Kitamura N, Maeda K and Shirakawa O (2008) Association of RGS2 Gene Polymorphisms with Suicide and Increased RGS2 Immunoreactivity in the Postmortem Brain of Suicide Victims. 33:1537-1544.

Ewald AWM, Bosch PJ, Culverhouse A, Crowley RS, Neuenswander B, Prisinzano TE and Kivell BM (2017) The C-2 derivatives of salvinorin A, ethoxymethyl ether Sal B and beta-tetrahydropyran Sal B, have anti-cocaine properties with minimal side effects. Psychopharmacology (Berl) 234:2499-2514.

Gomes T, Mamdani MM, Dhalla IA, Paterson JM and Juurlink DN (2011) Opioid Dose and Drug-Related Mortality in Patients With Nonmalignant Pain. Archives of Internal Medicine 171.

Hernandez A, Soto-Moyano R, Mestre C, Eschalier A, Pelissier T, Paeile C and Contreras E (1995) Intrathecal pertussis toxin but not cyclic AMP blocks kappa opioid-induced antinociception in rat. Int J Neurosci 81:193-197. 
Kozono H, Yoshitani H and Nakano R (2018) Post-marketing surveillance study of the safety and efficacy of nalfurafine hydrochloride (Remitch((R)) capsules $2.5 \mathrm{mug}$ ) in 3,762 hemodialysis patients with intractable pruritus. Int J Nephrol Renovasc Dis 11:9-24.

Kumar D, Chakraborty J and Das S (2012) Epistatic effects between variants of kappa-opioid receptor gene and A118G of mu-opioid receptor gene increase susceptibility to addiction in Indian population. Prog Neuropsychopharmacol Biol Psychiatry 36:225-230.

Kumor KM, Haertzen CA, Johnson RE, Kocher T and Jasinski D (1986) Human psychopharmacology of ketocyclazocine as compared with cyclazocine, morphine and placebo. J Pharmacol Exp Ther 238:960968.

Kuzmin AV, Semenova S, Gerrits MA, Zvartau EE and Van Ree JM (1997) Kappa-opioid receptor agonist U50,488H modulates cocaine and morphine self-administration in drug-naive rats and mice. Eur $J$ Pharmacol 321:265-271.

Lazenka ML, Moerke MJ, Townsend EA, Freeman KB, Carroll FI and Negus SS (2018) Dissociable effects of the kappa opioid receptor agonist nalfurafine on pain/itch-stimulated and pain/itch-depressed behaviors in male rats. Psychopharmacology 235:203-213.

Leander JD, Zerbe RL and Hart JC (1985) Diuresis and suppression of vasopressin by kappa opioids: comparison with mu and delta opioids and clonidine. Journal of Pharmacology and Experimental Therapeutics 234:463.

Lifschytz T, Broner EC, Zozulinsky P, Slonimsky A, Eitan R, Greenbaum L and Lerer B (2012) Relationship between Rgs2 gene expression level and anxiety and depression-like behaviour in a mutant mouse model: serotonergic involvement. 15:1307-1318.

Lindholm S, Werme M, Brene S and Franck J (2001) The selective kappa-opioid receptor agonist U50,488H attenuates voluntary ethanol intake in the rat. Behav Brain Res 120:137-146. 
Liu JJ, Chiu YT, DiMattio KM, Chen C, Huang P, Gentile TA, Muschamp JW, Cowan A, Mann M and LiuChen LY (2018) Phosphoproteomic approach for agonist-specific signaling in mouse brains: mTOR pathway is involved in kappa opioid aversion. Neuropsychopharmacology.

Marshalek PJ and Sullivan CR (2010) Buprenorphine clinics: an integrated and multidisciplinary approach to treating opioid dependence. $W V$ Med $J$ 106:60-63.

Massaly N, Moron JA and Al-Hasani R (2016) A Trigger for Opioid Misuse: Chronic Pain and Stress Dysregulate the Mesolimbic Pathway and Kappa Opioid System. Front Neurosci 10:480.

McAlindon TE, Bannuru RR, Sullivan MC, Arden NK, Berenbaum F, Bierma-Zeinstra SM, Hawker GA, Henrotin Y, Hunter DJ, Kawaguchi H, Kwoh K, Lohmander S, Rannou F, Roos EM and Underwood M (2014) OARSI guidelines for the non-surgical management of knee osteoarthritis. Osteoarthritis and Cartilage 22:363-388.

Morani AS, Kivell B, Prisinzano TE and Schenk S (2009) Effect of kappa-opioid receptor agonists U69593, U50488H, spiradoline and salvinorin A on cocaine-induced drug-seeking in rats. Pharmacol Biochem Behav 94:244-249.

Oliveira-Dos-Santos AJ, Matsumoto G, Snow BE, Bai D, Houston FP, Whishaw IQ, Mariathasan S, Sasaki T, Wakeham A, Ohashi PS, Roder JC, Barnes CA, Siderovski DP and Penninger JM (2000) Regulation of T cell activation, anxiety, and male aggression by RGS2. Proc Natl Acad Sci U S A 97:12272-12277. Porreca F and Navratilova E (2017) Reward, motivation, and emotion of pain and its relief. PAIN 158:S43-S49. Przewlocki R and Przewlocka B (2005) Opioids in Neuropathic Pain. Current Pharmaceutical Design 11:30133025.

Shippenberg TS, LeFevour A and Thompson AC (1998) Sensitization to the conditioned rewarding effects of morphine and cocaine: differential effects of the $\kappa$-opioid receptor agonist U69593. European Journal of Pharmacology 345:27-34. 
Siderovski DP, Blum S, Forsdyke RE and Forsdyke DR (1990) A set of human putative lymphocyte G0/G1 switch genes includes genes homologous to rodent cytokine and zinc finger protein-encoding genes. DNA Cell Biol 9:579-587.

Siderovski DP, Heximer SP and Forsdyke DR (1994) A human gene encoding a putative basic helix-loop-helix phosphoprotein whose mRNA increases rapidly in cycloheximide-treated blood mononuclear cells. DNA Cell Biol 13:125-147.

Siderovski DP and Setola V (2018) F1000Prime Recommendation of [Kozono H et al., Int J Nephrol Renovasc Dis 2018 11:9-24]. F1000Prime.

Smoller JW, Paulus MP, Fagerness JA, Purcell S, Yamaki LH, Hirshfeld-Becker D, Biederman J, Rosenbaum JF, Gelernter J and Stein MB (2008) Influence of RGS2 on anxiety-related temperament, personality, and brain function. Arch Gen Psychiatry 65:298-308.

Stein MB, Keshaviah A, Haddad SA, Van Ameringen M, Simon NM, Pollack MH and Smoller JW (2014) Influence of RGS2 on sertraline treatment for social anxiety disorder. Neuropsychopharmacology 39:1340-1346.

Tan EC, Lim EC, Teo YY, Lim Y, Law HY and Sia AT (2009) Ethnicity and OPRM variant independently predict pain perception and patient-controlled analgesia usage for post-operative pain. Mol Pain 5:32.

Tao PL, Liang KW, Sung WY, Wu YT and Huang EY (2006) Nalbuphine is effective in decreasing the rewarding effect induced by morphine in rats. Drug Alcohol Depend 84:175-181.

Tejeda HA and Bonci A (2018) Dynorphin/kappa-opioid receptor control of dopamine dynamics: Implications for negative affective states and psychiatric disorders. Brain Res.

Townsend EA, Naylor JE, Negus SS, Edwards SR, Qureshi HN, McLendon HW, McCurdy CR, Kapanda CN, do Carmo JM, da Silva FS, Hall JE, Sufka KJ and Freeman KB (2017) Effects of nalfurafine on the reinforcing, thermal antinociceptive, and respiratory-depressant effects of oxycodone: modeling an abuse-deterrent opioid analgesic in rats. Psychopharmacology (Berl):10.1007/s00213-00017-0465200213. 
Tsuji M, Takeda H, Matsumiya T, Nagase H, Narita M and Suzuki T (2001) The novel kappa-opioid receptor agonist TRK-820 suppresses the rewarding and locomotor-enhancing effects of morphine in mice. Life Sci 68:1717-1725.

Ueno Y, Mori A and Yanagita T (2013) One year long-term study on abuse liability of nalfurafine in hemodialysis patients. Int J Clin Pharmacol Ther 51:823-831.

Urs NM, Gee SM, Pack TF, McCorvy JD, Evron T, Snyder JC, Yang X, Rodriguiz RM, Borrelli E, Wetsel WC, Jin J, Roth BL, O'Donnell P and Caron MG (2016) Distinct cortical and striatal actions of a betaarrestin-biased dopamine D2 receptor ligand reveal unique antipsychotic-like properties. Proc Natl Acad Sci U S A 113:E8178-E8186.

Walsh SL, Chausmer AE, Strain EC and Bigelow GE (2008) Evaluation of the mu and kappa opioid actions of butorphanol in humans through differential naltrexone blockade. Psychopharmacology (Berl) 196:143155.

Webster LR (2015) Opioid-Induced Constipation. 16:S16-S21.

Wee S and Koob GF (2010) The role of the dynorphin- $\kappa$ opioid system in the reinforcing effects of drugs of abuse. Psychopharmacology 210:121-135.

White KL, Robinson JE, Zhu H, DiBerto JF, Polepally PR, Zjawiony JK, Nichols DE, Malanga CJ and Roth BL (2015) The G protein-biased kappa-opioid receptor agonist RB-64 is analgesic with a unique spectrum of activities in vivo. $J$ Pharmacol Exp Ther 352:98-109.

Wu HK, Heng HH, Shi XM, Forsdyke DR, Tsui LC, Mak TW, Minden MD and Siderovski DP (1995) Differential expression of a basic helix-loop-helix phosphoprotein gene, G0S8, in acute leukemia and localization to human chromosome 1q31. Leukemia 9:1291-1298.

Zacny JP, Lichtor JL, Thapar P, Coalson DW, Flemming D and Thompson WK (1994) Comparing the subjective, psychomotor and physiological effects of intravenous butorphanol and morphine in healthy volunteers. J Pharmacol Exp Ther 270:579-588. 
Zhang Y, Picetti R, Butelman ER, Ho A, Blendy JA and Kreek MJ (2014) Mouse Model of the OPRM1 (A118G) Polymorphism: Differential Heroin Self-Administration Behavior Compared with Wild-Type Mice. 40:1091-1100.

Zheng WH, Wakim RJ, Geary RC, Lander LR, Wen SJ, Xiao MC and Sullivan CR (2016) Self-reported Sleep Improvement in Buprenorphine MAT (Medication Assisted Treatment) Population. Austin J Drug Abuse Addict 3.

Zhu L, Rossi M, Cui Y, Lee RJ, Sakamoto W, Perry NA, Urs NM, Caron MG, Gurevich VV, Godlewski G, Kunos G, Chen M, Chen W and Wess J (2017) Hepatic beta-arrestin 2 is essential for maintaining euglycemia. J Clin Invest 127:2941-2945. 